Opuscula

Annual of the Swedish Institutes at Athens and Rome<smiles>[10BH2]</smiles> 


\section{On the dating of two early 2nd century coin issues from Kos and the IGCH I320 hoard}

\begin{abstract}
*
This paper presents and discusses the dates of two Koan silver issues, drachms with young Herakles/crab and club in incuse, and hemidrachms with Apollo/lyre. A date in the 190s BC is suggested on several grounds. Weights and diameters correspond with those of HI XII and XIII of the 3 rd century, suggesting that the issues discussed here followed shortly thereafter. The other Koan silver issues of the 2 nd century were minted on a lower weight-standard. The IGCH 1320 hoard contains examples of both issues, and the other Koan issues in it date to the middle and second half of the 3rd century or the 190s/c. 190. Groups of homonyms occur in issues dating to the end of 3 rd/early 2 nd century. A connection with Kalymnos seems likely for the hemidrachms, and this may suggest a date early in the 190s during the war with king Philip V of Macedonia.
\end{abstract}

* I am most grateful to Pierre Requier for letting me use his private catalogue of coins containing a number of previously unpublished examples; most of the coins listed here were collected by him. His comments on the manuscript in various stages have been of great aid. Vassiliki Stefanaki generously gave me permission to include some coins located and identified by her. She has read an earlier version of the manuscript, enhancing it with her comments. I am also grateful to Peter van Alfen for his help with the Rhodian plinthophoric drachms from $I G C H$ 1321, to Panagiotis Iossif for discussing various issues pertaining to the article, to Warren Esty for his important contribution concerning the estimated number of original dies, and to the anonymous readers for helpful comments which have increased the quality of the paper. Any mistakes are my own. Several museums have provided excellent photographs. My thanks go to the photographers in Berlin (R. Saczewski, Staatliche Museen zu Berlin-Preussischer Kulturbesitz. Münzkabinett), London (K. Wenger, British Museum) (c) Copyright courtesy of The Trustees of the British Museum, New York (E. Stolyarik, the American Numismatic Society, ANS), Glasgow (Hunterian Museum, University of Glasgow), and Oxford (V. Heuchert, Ashmolean). I am also grateful to the Numismatic Museum in Athens, the National Museum in Copenhagen and the Bibliotheque Nationale de France in Paris for permission to have coins photographed. Credits for photographs from these museums are as follows: Athens, M. Mauzy; Copenhagen, H. Kanger; Paris, P. Requier; Kos, V. Stefanaki.
This study concerns two issues of Koan silver, drachms and hemidrachms on the Rhodian standard, presently dated to the 170 s. $^{1}$ The drachms show a head of young Herakles r./ crab, club, and the hemidrachms a head of Apollo r./lyre. They belong to a transitional period in the history of the Koan mint with both conservative and innovative traits. ${ }^{2}$ As only a comparatively small number of coins is known from both issues, no full study of them was made until the early 2000 s when $\mathrm{H}$. Ingvaldsen presented them. ${ }^{3}$ Using a substantially enlarged body of data, the aim here is to reinvestigate the issues in order to establish a more secure dating and to see how they fit into what we know of Koan history. A review of $I G C H 1320$, the only published hoard containing coins from these two issues, is also included. ${ }^{4}$

The catalogues below contain 44 drachms with eight names and 45 hemidrachms with 16 , six of the names being

\footnotetext{
1 All dates are $\mathrm{BC}$ unless otherwise stated. The two issues were first connected by Robinson in 1936 when he pointed out that they shared three names.

2 The estimated weight standard of both issues is the same as the $3 \mathrm{rd}$ century issues. The drachms form one of the last silver issues depicting Herakles on the obverse whereas the hemidrachms showing Apollo, the father of Asklepios, present a new obverse type. Herakles had for two centuries been the main deity on Koan coins, but from c. 200 Asklepios took his place.

3 Ingvaldsen 2002, issues XXIII and XXIV.

4 It is the only Koan hoard from this period which contains more than two different issues, both silver, from three different mints and Koan bronze. It has thus played a central role in previous discussions. Ingvaldsen $(2002,158)$ reported that one drachm and two hemidrachms (ANS nos. 1944.10048492-94) belong to the unpublished IGCH 1321 hoard found on Rhodes and reportedly containing c. 400 coins (Noe 1937, no. 864). The ANS tickets for nos. 1944.10048492 and 1944.10048493 confirm this. The ANS also holds 24 of the Rhodian drachms from this hoard. They are still unpublished, but photographs were, in April 2012, placed on the ANS homepage. According to Ingvaldsen (2002, 158, n. 495) they are not included in Jenkins's 1989 lists.
} 
common to both. There are altogether 89 coins, 48 obverse dies and 18 names. ${ }^{5}$ In 2002 Ingvaldsen listed a total of 48 coins, 30 obverse dies and seven names. ${ }^{6} \mathrm{He}$ was the first to discuss the issues in a comprehensive way. About a century earlier Head had published and dated the few specimens in the BM; later studies by Robinson (1936) and Kroll (1964) did not focus on these particular issues, and their conclusions were based on the few coins in the coin hoard IGCH 1320. Originally the issues would have been large, almost certainly larger than the 3rd century issues of drachms and hemidrachms, HI XII and XIII (see Appendix), but, as already Ingvaldsen noted, they were minted over a much shorter period of probably less than ten years, as compared with over 50 years for HI XII and XIII.

I received Stefanaki's volume $K \Omega \Sigma$ I after the manuscript had been submitted and I have thus not been able to include her published results. Some information had been given me earlier and in these instances I have noted the page numbers of her volume in my references. I have also inlcuded her catalogue numbers in my catalogue.

\section{Catalogues and discussion}

Only some of the coins listed below can be placed in a relative chronological order, but I have placed the dies known to be earlier before later ones. ${ }^{8}$

\section{DRACHMS (PLS. I-3)}

$O b v$. Head of young Herakles $\mathrm{r}$.

Rev. Crab; below, club. Above crab, $K \Omega I \Omega N$; below club, name. All in shallow incuse square. On most coins one or two control letters are placed left and/or right of the claws of the $\operatorname{crab}(\Delta, \mathrm{E}, \mathrm{K}$ and $\mathrm{KE}) . ?$

\section{No. Obv/Rev Weight Axis Diam}
(g)
(h) $(\mathrm{mm})$

\begin{tabular}{|c|c|c|c|c|c|}
\hline \multicolumn{6}{|c|}{$\operatorname{APXIA\Sigma }(\Delta, \mathrm{K}, \mathrm{K} E)$} \\
\hline 1. & $1 / 1$ & 2.49 & 12 & & $\begin{array}{l}\text { New York, ANS } 1960.170 . \\
\left.287 \text { (HI 5a, VS } 1693^{10}\right) . \\
\text { Pl. } 1\end{array}$ \\
\hline 2. & $2 a^{11} / 2$ & 3.36 & 11 & 15 & $\begin{array}{l}\text { Paris, BN 1211, K left of } 1 . \\
\text { claw. (VS 1691) Pl. } 1\end{array}$ \\
\hline 3. & $2 b / 3$ & 3.02 & 12 & 16 & $\begin{array}{l}\text { London, } B M C 118 \text {, Kright } \\
\text { of r. claw (HI 6a, VS 1692). } \\
\text { Pl. } 1\end{array}$ \\
\hline 4. & $2 / 4$ & 2.98 & & & $\begin{array}{l}\text { Karlsruhe, Badisches Landes- } \\
\text { museum (VS 1695) K E. }\end{array}$ \\
\hline 5. & $3 a / 5$ & 3.13 & 12 & 15 & $\begin{array}{l}\text { Oxford, IGCH } 1320 \text { (Rob- } \\
\text { inson } 1936,193 \text { ), K left of } 1 \text {. } \\
\text { claw, E right of r. claw (HI } \\
\text { 7a, VS 1697). Pl. } 1\end{array}$ \\
\hline 6. & $3 c / 6$ & 3.09 & 12 & 16 & $\begin{array}{l}\text { Paris, BN } 1209 \text {, K left of } 1 . \\
\text { claw, E right of r. claw (VS } \\
\text { 1694). Pl. } 1\end{array}$ \\
\hline 7. & $4 / ?$ & 2.66 & 12 & 18 & $\begin{array}{l}\text { Athens } 5658 \mathrm{a}, \mathrm{K} \text { left of } \mathrm{l} \text {. } \\
\text { claw, E(?) right of r. claw } \\
\text { (HI 8a, VS 1698). Pl. } 1\end{array}$ \\
\hline 8. & $5 / 7$ & 2.86 & 12 & 15 & $\begin{array}{l}\text { London, } B M C 117, \Delta \text { left } \\
\text { of l. claw (HI 4a, VS 1690). } \\
\text { Pl. } 1\end{array}$ \\
\hline
\end{tabular}

5 The lists of coins presented in this article are the result of the efforts of several persons. Without the generous aid of P. Requier and V. Stefanaki they would not contain the present number of coins. When searching for coins belonging to these two issues the major museums were covered as were the relevant institutions in Greece. As for the market, over the last 20 years the major part of it was covered by Pierre Requier. Vassiliki Stefanaki made a separate search and our results were then pooled. I think that, between us, we have covered most of the extant examples, but some may have escaped our notice.

6 Coins of these two issues rarely appear on the market. Most of the previously unpublished coins presented here belong to the collections in Berlin and Paris which, except for one coin, were not included in Ingvaldsen's study.

$7 \mathrm{HI}+$ Roman numeral stands for number of issue in Ingvaldsen's catalogue of coins (Ingvaldsen 2002).

\footnotetext{
8 Abbreviations: ANS = American Numesmatic Society; BN = Bibliothèque Nationale; $B M C=$ British Museum Catalogue of coins 19, Caria and islands; Mk = Staatliche Museen zu Berlin, Preussische Kulturbesitz Münzkabinett.

9 Information on cat. nos. 4 and 29 was provided by V. Stefanaki.

$10 \mathrm{HI}+$ number stands for coins in Ingvaldsen's 2002 catalogue of issue XXIII; VS + number stands for coins in Stefanaki 2012.

11 The small letters indicate the order, determined by die wear, in which the obverse dies were used.
} 
9. $6 a / 8 \quad 2.80 \quad 12 \quad 16$ Paris, BN 1207 (Waddington 2788), $\Delta$ left of l. claw (VS 1689). Pl. 1

$\operatorname{ApATO} \Sigma(\Delta, \mathrm{K})$

10. $6 \mathrm{~b} / 9 \quad 3.05 \quad 12 \quad 16$ Berlin, Mk 18211754, acq. 1900 Imhoof-Blumer, $\Delta$ left of l. claw (VS 1685). Pl. 1

11. $7 / 10 \quad 3.14 \quad 12 \quad 15$ Oxford, Oman 1947, K left ofl. claw (HI 1a, VS 1686). Pl. 1

12. $8 / 11 \quad 2.63 \quad 12 \quad 17$ London, Robinson 1934-312-15, IGCH 1320, K right of r. claw (HI 2a, VS 1687). Pl. 1

13. $9 / 12 \quad 2.92 \quad 12 \quad 16$ Paris, BN 1206, (Waddington 2737, HI 3a, VS 1688). Pl. 1

$\operatorname{API} \Sigma T A I(O) \Sigma(K E)$

14. $3 \mathrm{~b} / 13 \quad 2.97$

1117 Kosmuseum, N706, Obolos 8,133,pl.I.12(Grigoriadou), $\mathrm{K}$ left of l. claw, $\mathrm{E}($ ?) right of r. claw (VS 1699). Pl. 2

15. $10 \mathrm{a} / 14 \mathrm{a} 3.02$

1215 London, Robinson 1934-312-16, IGCH 1320, K left of l. claw, $\mathrm{E}($ ?) right of $\mathrm{r}$. claw (HI 9e, VS 1706).Pl. 2

16. $10 \mathrm{~b} / 14 \mathrm{~b} \quad 2.95 \quad 1 \quad 17$ Paris, BN 1210, K left of 1 . claw (VS 1701). Pl. 2

17. $10 \mathrm{c} / 14 \mathrm{c} 2.48 \quad 12 \quad 14$ Berlin, Mk 18211755, acq. 1925 Kassel, K left of 1. claw, $\mathrm{E}($ ?) right of r. claw (VS 1708).Pl. 2

18. $10 \mathrm{~d} / 14 \mathrm{~d} 2.78 \quad 12 \quad 15$ Oxford, Milne 1924, K left of 1 . claw, $\mathrm{E}($ ?) right of $\mathrm{r}$. claw (HI 9a, VS 1702).Pl. 2

19. $10 \mathrm{e} / 14 \mathrm{e} \quad 2.64 \quad 6 \quad 14.5$ Vienna, KHM 18503. (VS 1700) Pl. 2

20. $10 \mathrm{f} / 14 \mathrm{f} 2.61 \quad 15$ Glasgow, Hunterian Coll. Vol. II, p. 433, no. 11, K left ofl. claw (?) (VS 1710).Pl. 2

21. $10 \mathrm{~g} / 14 \mathrm{~g} \quad 2.45 \quad 2 \quad$ New York, ANS 0000.999. 20798, K left of l. claw, E (?) right of r. claw (HI 9f, VS 1707). Pl. 2

22. $10 / 14$

15 Dresden 1297 (HI 9b, VS 1703)

23. $10 / 14 \quad 2.50 \quad 2 \quad 17$ SNGMünchen 22, no. 512, Taf. 27 (HI 9c, VS 1709).
24. $10 / 14 \quad 2.62$
1215 Leiden 6217 (HI 9d, VS 1704).
25. $10 / 14 \quad 2.65$
15 Kress 107 (1958), 92 (HI 9g, VS 1705).

ПАТРОК $\Lambda \mathrm{H} \Sigma(\Delta)$

26. $11 / 15 \quad 3.05$

1217 London, Robinson 1934-312-14, IGCH 1320, $\Delta$ left of 1 . claw (HI 15a, VS 1722). Pl. 2

27. $12 / 16 \quad 3.06 \quad 12 \quad 16$ Berlin, Mk 18211758, acq. 1906 Löbbecke, $\Delta$ left of 1 . claw (VS 1718). Pl. 2

28. $13 / 172.88 \quad 12 \quad 17$ Cambridge McClean 8546, pl.298.28.ПАТ[POK $\Lambda \mathrm{H} \Sigma$ ], $\Delta$ (?) (VS 1720).

29. $14 / 18 \quad 3.03 \quad 12 \quad 17$ Kos museum, N 2253, $\Delta$. (VS 1719).

30. $15 \mathrm{a} / 19 \quad 3.18 \quad 12 \quad 16$ London, Robinson 1934-312-18, IGCH 1320, $\triangle$ right of r. claw, (HI 16a, VS 1721). Pl. 2

\section{$\triangle$ IOTIMO}

31. $15 \mathrm{~b} / 20 \quad 2.39 \quad 12 \quad 17$ Berlin, Mk 18211756, acq. 1900 Imhoof-Blumer. (VS 1725) Pl. 2

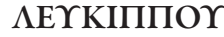

32. $16 \mathrm{a} /$ ? $\quad 3.03^{12} \quad 6 \quad$ Budapest MNM 51a 1913. 36 (HI 17a, VS 1724, Hirsch 25, 1909, 2413).

33. $16 \mathrm{~b} / 21 \quad 2.76 \quad 12 \quad 16$ Berlin, Mk 18211757, Alter Bestand. (VS 1723) Pl. 3

\section{EY $\triangle \mathrm{AMO} \Sigma$}

34. $17 / 22 \quad 3.0299 \quad 15$ Paris, BN 1208, PH N 143. (VS 1726) Pl. 3

\section{API $\Sigma T A N \Delta P O \Sigma(E, K E)$}

35. $18 / 23 \quad 3.12 \quad 12 \quad 17$ London, Robinson 1934-312-17,IGCH1320, Kleft of 1. claw, E right of r. claw (HI 14a, VS 1717). Pl. 3

\footnotetext{
12 The weight is taken from Ingvaldsen's catalogue.
} 
36. $19 / 24 \quad 2.89 \quad 12$

37.

39. $21 / 26$

3.13

40. $22 / 27$

2.99

12

41. $23 a / 28$

2.92

42. $23 b / 29 \quad 2.67$

12

17

New York, ANS 1944.100. 48492, ex IGCH 1321, K left of l. claw, E right of $\mathrm{r}$. claw (HI 10a, VS 1714). Pl. 3

16 Ars Classica XVII, 1934, 571, Stock Hirsch, ex. Warren coll., K left of l. claw, E right of r. claw (HI 10b, VS 1714).

38. $20 / 25 \quad 3.14 \quad 12 \quad 17$ Oxford, Milne 17/10-1932 (N.Zitelli, Rhodes), IGCH 1320(Robinson 1936,193), $\mathrm{K}$ left of l. claw, E right of r. claw (HI 11 a, VS 1711). Pl. 3

Numismatica Genevensis 6, 2010/11,97; TRADART3, 1985/12, no 134; Münzzentrum 54, 1985, 242; Kölner Münzkab. 16, 1975, 134, $\mathrm{K}$ left of l. E right of $\mathrm{r}$. claw (HI 13a, VS 1716). Pl. 3

Burgan VSO 33, no. 76, K left of l. claw, E right of $\mathrm{r}$. claw (VS 1713). Pl. 3

18 Boston, Brett, Mus. Fine Arts Cat. 1955, 257, no. 2027 API $\Sigma T A N \Delta$ PO (last two letters in monogram acc. to ed.), E right of r. claw (HI 11a, VS 1712).
Oxford, Christ Church (1419), E right of r. claw (HI 12a, VS 1715).Pl. 3

No names readable $(\mathrm{HI})$

43.

(1.82) 12

44.

(1.94) 12

Fig. 1a. Weight table, Young Herakles/incuse drachms.

Fig. 1b. Weight table, Apollo hemidrachms.

\begin{tabular}{|c|c|c|}
\hline Weight ing & No of coins & \\
\hline $0.87^{\circ}$ & $\bullet$ & $(1)$ \\
\hline $1.00-1.09$ & $\bullet$ & (2) \\
\hline $1.10-1.19$ & •.•• & $(4)$ \\
\hline $1.20-1.29$ & ••••••• & (6) \\
\hline $1.30-1.39$ & 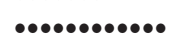 & (12) \\
\hline $1.40-1.49$ & $\bullet \bullet \bullet \bullet \bullet \bullet \bullet \bullet$ & (9) \\
\hline $1.50-1.59$ & •••• & (5) \\
\hline $1.60-1.69$ & $\bullet$ & (1) \\
\hline \multicolumn{2}{|c|}{ Total number of coins } & $(41)$ \\
\hline
\end{tabular}

\section{Characteristics}

Estimated weight standard and weight distribution ${ }^{13}$ (Fig. 1a) Recorded weights (41 coins) range from $2.39 \mathrm{~g}$ to $3.34 \mathrm{~g}$. Four examples weigh less than $2.60 \mathrm{~g}$ (excluding the corroded and damaged nos. 43 and 44). The vast majority, 35 coins, fall in the range $2.60-3.20 \mathrm{~g}$. Given that as many as eight coins in this limited sample weigh $3.10 \mathrm{~g}$ or more, and that some loss of weight should be due to wear, the weight standard is probably 3.20 or 3.30 g. ${ }^{14}$

\section{Die axes and flan diameters}

Of the 37 coins with recorded die-axes, 29 are at $12 \mathrm{~h}$, three at $11 \mathrm{~h}$ or $1 \mathrm{~h}$, two at $2 \mathrm{~h}$, two at $6 \mathrm{~h}$, and one at $9 \mathrm{~h}$. The diameter of the flans of the 36 coins for which I have information varies from $14 \mathrm{~mm}$ to $18 \mathrm{~mm}$. Two are $14 \mathrm{~mm}$ and two are $18 \mathrm{~mm}$. The rest are $15 \mathrm{~mm}$ (eleven specimens), 16 $\mathrm{mm}$ (nine specimens) and $17 \mathrm{~mm}$ (twelve specimens). Both obverse and reverse dies were well aligned with the flans when

13 The number of units analysed is too small to allow statistical reliability. I will therefore not use any statistical terms in my numerical analysis. 14 The estimate is based on the assumption that the issuing authority had an interest in keeping the weight of the minted coins at, or just below, the given weight standard. Any coins that were heavier would be issued at a loss (or at least less of a gain) to the mint. Occasional coins may have been above the standard, but the actual weight standard is here supposed to be higher than that of the heaviest group of coins showing wear in the issue (i.e. not isolated examples). 
Fig. 2. Herakles/incuse drachms and Apollo/lyre hemidrachms: control letters and homonyms in other issues.

\begin{tabular}{|c|c|c|c|}
\hline Name & Denom. & $\begin{array}{l}\text { Letters on } \\
d r . \text { (hemidr.) }\end{array}$ & $\begin{array}{l}\text { Occurence on } \\
\text { other issues }\end{array}$ \\
\hline Agesias & hemidr & & $\begin{array}{l}\text { KH } 2007 \text { A2-3, C1-5; Kroll 1964, } \\
\text { nos. 13, 14, 16, 17, 22; HI XIX.139-141 } \\
\text { HI XXI.71-73 }\end{array}$ \\
\hline Aratos & both & $\Delta \mathrm{K}$ & HI XVI, name third last, last die $c .200$ \\
\hline Aristai $(\mathrm{o}) \mathrm{s}$ & both & $\mathrm{K} \mathrm{E}(\mathrm{A})$ & \\
\hline Aristandros & drachm & $\mathrm{K} \mathrm{E}, \mathrm{E}$ & \\
\hline Aristoboulos & hemidr. & & \\
\hline Archias & both & $\Delta \mathrm{K}, \mathrm{KE}(\mathrm{A})$ & HI XXII? only -IA- on coin \\
\hline Diotimos & both & $(\mathrm{K} \mathrm{E})$ & \\
\hline Eudamos & drachm & & Kroll 1964, nos. 6, 30 \\
\hline Eukratou & hemidr. & & HI XIX.2; PH N217, N231 \\
\hline Thrasyandros & hemidr. & $(\mathrm{A})$ & \\
\hline Hieron & hemidr. & & HI XII, c. 205 \\
\hline Kallippidas & hemidr & & HI XII, c. 205 \\
\hline Kleufantos & hemidr & & HIXXI \\
\hline Kleonymida & hemidr. & & Kroll 1964, no. 2, K $\Lambda \mathrm{E} \Omega$ - could also be Kleonymos \\
\hline L(?)eukippou & both & & \\
\hline Nikon & hemidr. & & Kroll 1964, no. 11 \\
\hline Patrokles & both & $\Delta,(\mathrm{A})$ & \\
\hline P]armenis $[$ kos- & hemidr. & & Kroll 1964 , nos. $14,20,28$, \\
\hline & & & ПАРM/E \\
\hline & & & HI XXI, ПАРMEN \\
\hline & & & HI XVI, XIX, \\
\hline & & & ПAPMENI $\Sigma \mathrm{KO}$ \\
\hline
\end{tabular}

struck. Only very rarely is a small part of the Herakles head off flan, and on the reverse the incuse is, with one exception, completely on flan.

The control letters (Fig. 2)

At least 31 of the 40 coins have control letters on the reverse, namely $\Delta, \mathrm{E}, \mathrm{K}$, and $\mathrm{K} \mathrm{E} .{ }^{15}$ They are placed either left of the left claw of the crab $(\Delta$ and $\mathrm{K})$, right of the right claw $(\Delta, \mathrm{E}$ and $\mathrm{K}$ ), or $\mathrm{K}$ left of left claw combined with $\mathrm{E}$ right of right claw.

Archias, Aratos and Patrokles have $\Delta$ left of the left claw. Patrokles also has $\Delta$ right of the right claw. Archias and Aratos also have $\mathrm{K}$ left of the left claw and $\mathrm{K}$ right of the right claw. Aristandros has E right of the right claw. Archias, Aristai(o) $s$ and Aristandros have $\mathrm{K}$ left of the left claw combined with E right of the right claw. Archias, Aratos and Eudamos mint coins with no control letter. ${ }^{16}$

15 As yet we don't know the function of the Koan control letters.

16 The coins of Diotimos and Leukippos may also have lacked control letters, but their heavy wear makes this impossible to ascertain.
The ratio of names to coins and obverse dies

The number of obverse dies is 23 . The eight readable names (here given in Greek with the enclitic signs) are in alphabeti-

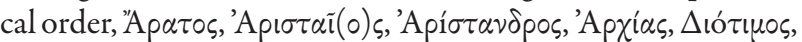
Eủdauos, $\Lambda \varepsilon v ́ \kappa ı \pi \pi \circ \varsigma$ and $\Pi \alpha \tau \rho \circ \kappa \lambda \tilde{\eta}$. All but two (Aristandros and Eudamos) also appear on the Apollo/lyre hemidrachms. In one case the name is given in the genitive, Leukippou (nos. 32 and 33).

The number of coins (n) and obverse dies (d) are as follows:

$\begin{array}{lll}\text { Name } & n & d \\ \text { Archias } & 8 & 6 \\ \text { Aratos } & 4 & 4 \\ \text { Aristai(o)s } & 11 & 2 \\ \text { Patrokles } & 4 & 4 \\ \text { Diotimos } & 1 & 1 \\ \text { Eudamos } & 1 & 1 \\ \text { Leukippos } & 3(\text { ?) } & 1 \text { (or 2) } \\ \text { Aristandros } & 8 & 6 \\ \text { unknown } & 2 & 2\end{array}$


Archias and Aristandros, with six dies each, used the largest number of dies, Aratos and Patrokles used four dies each, the others one or two.

\section{Links between moneyers (Fig. 3)}

I have used three different criteria to establish linkages: a) shared obverse die, b) same control letter (but not all coins display one), and c) same reverse die-cutter (based on an analysis of the lettering). ${ }^{17}$ To this I have added two external features, appearance in $I G C H 1320$ and in the inscription on Paton \& Hicks no. 10 (PH 10) dating to 201/0.

Three obverse dies have been used by two moneyers. The order in which the different magistrates ${ }^{18}$ used the same die is determined by its deterioration as seen on the coins in the form of a gradual blurring of lines and details not due to ordinary wear. Die O3 links Archias and Aristai(o)s who used it alternately. Die O6 links Archias who used the die first, with Aratos. Die O15 links Patrokles with Diotimos who used it after Patrokles.

It is clear that Archias and Aratos worked together. They shared not only the obverse die O6, but also the control letter $\mathrm{K}$, positioned both left of the left claw and right of right claw. Both also minted coins with no control letter/s; as at least $75 \%$ of the coins in this series have control letters this is significant. They probably used the same die-cutter, as the lettering on coins nos. 1 (Archias) and 11 (Aratos) is closely similar, with marked end dots at the end of the strokes; on certain letters, for instance $c h i$ and sigma, they are the dominant feature (cluster A). Patrokles also produced coins with these features (nos. 26, 30). ${ }^{19}$

Archias also shared an obverse die (O3) with Aristai(o)s, used first by Archias, then Aristai(o)s, and then again by Archias. Three of Archias's reverse dies (coins nos. 4-6) have the same control letters used by Aristai(o)s and Aristandros: $\mathrm{K}$ left of left claw and $\mathrm{E}$ right of right claw. Aristai(o)s seems to use only this combination, whereas Aristandros also had E right of right claw (coin no. 42). There is thus a close connection between Archias, Aratos and Aristaios. Aristandros is also connected, but not as closely.

Both Archias and Aratos are linked to Patrokles through the use of the control letter $\Delta$ placed left of the left claw. Patrokles is also linked to Diotimos with whom he shares one obverse die (O15).

Coins of Aratos, Aristaios, Aristandros, Archias and Patrokles, all with next to no wear, appear in the IGCH 1320 hoard. ${ }^{20}$ This and the other links just noted suggest that they were all minted within a short period.

\begin{tabular}{|c|c|c|c|c|c|}
\hline \multicolumn{4}{|l|}{ Internal links } & \multicolumn{2}{|c|}{ External links } \\
\hline Name & Die (coin no.) & Control letter (coin no) & $\begin{array}{l}\text { Letter cutter } \\
\text { cluster } \\
\text { (coin no) }\end{array}$ & $\begin{array}{l}\text { In IGCH } \\
1320 \\
(\operatorname{coin} n o)\end{array}$ & $\begin{array}{l}\text { Name also } \\
\text { in PH10 }\end{array}$ \\
\hline Archias & $3 a, c(5,6) 6 a(9)$ & $\begin{array}{l}\Delta(8,9) \\
\mathrm{K}(2,3), \\
\mathrm{KE}(4,5,6,7(?))\end{array}$ & $\mathrm{A}(1)$ & $\mathrm{x}(5)$ & \\
\hline Aratos & $6 \mathrm{~b}(10)$ & $\begin{array}{l}\Delta(10) \\
\mathrm{K}(11,12)\end{array}$ & $\mathrm{A}(11)$ & $\mathrm{x}(12)$ & $\mathrm{x}$ \\
\hline Aristai $(\mathrm{o}) \mathrm{s}$ & $3 \mathrm{~b}(14)$ & $\mathrm{KE}(?)(14,15,17,18,21)$ & & $\mathrm{x}(15)$ & \\
\hline Patrokles & $15 \mathrm{a}(30)$ & $\Delta(26,27,28(?), 29,30)$ & & $x(26,30)$ & \\
\hline Diotimos & $15 \mathrm{~b}(31)$ & & & & \\
\hline Leukippos & & & $\mathrm{B}(33)$ & & \\
\hline Eudamos & & & $\mathrm{B}(34)$ & & \\
\hline Aristandros & & $\mathrm{KE}(35-40)$ & $\mathrm{B}(38)$ & $x(35)$ & \\
\hline
\end{tabular}

Fig. 3. Herakles/incuse drachms, internal and external links.

17 Coins with the same/closely similar stylistic or other traits have been grouped in clusters. As these coins all belong to one issue, most of whose moneyers are die-linked; the clusters are presumed to be the work of the same die-cutter.

18 The term is here used in a general sense, denoting the person appointed by the polis to be responsible for an issue.
19 For my view on the value of stylistic analysis see p. 289.

20 This is in contrast to the coins belonging to the bearded Herakles issue from the same hoard which show heavier wear. 
The style of the lettering of the ethnic indicates a relationship between coins 33 (Leukippos), 34 (Eudamos), and 38 (Aristandros). All three have an initial kappa with end bars instead of the dots which are much more frequent in this issue. The omega has the same appearance; it is small with long horizontal bars. The iota is long with marked end bars (cluster B). The die of Eudamos is unusually well executed. The lettering on the coins of Leukippos is sloppy. The Aristandros die shows heavy wear probably due to intensive use.

To sum up, the linkages connect all names more or less and the issue thus forms only one group, the core of which was made up of Archias, Aratos, Aristaios and Patrokles. This pattern strongly indicates that the coins were issued within a short period of time.

\section{A comparison with other Koan silver issues (Fig. 4)}

The drachms with head of the young Herakles r./crab, club in incuse can be compared to the earlier issue of drachms with head of bearded Herakles r./crab, club, ending just before 200. We have 206 coins $^{21}$ from the earlier issue, against only 44 specimens of the later. The young Herakles/incuse issue has both conservative and innovative traits. I will first present the similarities with the previous issue.

\section{Similarities}

The two issues of drachms have the same estimated weight standard, the same types on obverse (head of Herakles r. $)^{22}$ and reverse (crab, club), the same position for the legends on the reverse, the same die-axes, and just about the same flan diameter.

Both issues show the same distribution of weights with some examples below $2.60 \mathrm{~g}$ and an occasional example over $3.20 \mathrm{~g}$. The vast majority of the coins in both issues range from c. $2.60 \mathrm{~g}$ to $3.20 \mathrm{~g}$, HI XII, 161 coins, young Herakles/incuse drachms, 39 coins. Given that as many as 24 specimens of the earlier issue and eight of the later weigh $3.10 \mathrm{~g}$ or more, and that many coins have lost weight due to wear, I suggest that the weight standard of both issues is 3.20 or $3.30 \mathrm{~g}$. Ingvaldsen 2002 suggested $3.10 \mathrm{~g}$, but this seems fractionally too low. ${ }^{23}$

The die-axis pattern of the two issues of drachms corresponds closely. Ingvaldsen writes that the old Herakles drachms mostly show a $12 \mathrm{~h}$ axis, but with some exceptions, eight specimens having a $6 \mathrm{~h}$ axis and three specimens a $3 \mathrm{~h}$ axis. ${ }^{24}$ As seen above, the $12 \mathrm{~h}$ axis also dominates in the young Herakles issue, with some exceptions showing a 6 h, 9 h, or $2 \mathrm{~h}$ axis. In earlier Koan silver issues the $6 \mathrm{~h}$ axis was the most common one.
Fig. 4. A comparison of the Herakles/crab, club and the young Herakles/incuse drachms.

\begin{tabular}{|c|c|c|}
\hline Feature & Herakles/crab, club $d r$ & Young Herakles/incuse $d r$ \\
\hline & \multicolumn{2}{|c|}{ Similarities } \\
\hline Weight spread & $\begin{array}{l}2.60-3.20 \mathrm{~g}, 81 \%(167 \text { coins }) \\
3.10 \mathrm{~g} \text { or more, } 12 \% \text { ( } 24 \text { coins })\end{array}$ & $\begin{array}{l}2.60-3.10 \mathrm{~g}, 80 \%(35 \text { coins }) \\
3.10 \text { g or more, } 18 \% \text { ( } 8 \text { coins })\end{array}$ \\
\hline $\begin{array}{l}\text { Estimated } \\
\text { weight standard }\end{array}$ & 3.20 or $3.30 \mathrm{~g}$ & 3.20 or $3.30 \mathrm{~g}$ \\
\hline Normal die axis & $12 \mathrm{~h}$ & $12 \mathrm{~h}$ \\
\hline Flan diameter & $\begin{array}{l}15-16 \mathrm{~mm}(35 \text { coins }) \\
17 \mathrm{~mm}(7 \text { coins })\end{array}$ & $\begin{array}{l}15-16 \mathrm{~mm} \text { ( } 20 \text { coins }) \\
17 \mathrm{~mm} \text { ( } 12 \text { coins }) \\
18 \mathrm{~mm}(2 \text { coins })\end{array}$ \\
\hline \multirow[t]{2}{*}{ Motif } & Head of Herakles/crab, club & Head of Herakles/crab, club \\
\hline & \multicolumn{2}{|c|}{ Differences } \\
\hline Incuse & & $\mathrm{x}$ (all coins) \\
\hline Ethnic & $\mathrm{K} \Omega \mathrm{ION}$ & $\mathrm{K} \Omega \mathrm{I} \Omega \mathrm{N}$ \\
\hline Control letter & - & $\Delta, \mathrm{E}, \mathrm{K}, \mathrm{KE}$ \\
\hline
\end{tabular}

21 Ingvaldsen published 189 coins in 2002 and Höghammar another 17 coins in 2006
22 On the 3rd century drachms the old Herakles, on the incuse drachms the young Herakles.

23 Ingvaldsen 2002, 376.

24 Ingvaldsen 2002, 118. 
The diameter of the flans of the two issues of drachms also corresponds closely. Ingvaldsen 2002 does not give the diameter of the bearded Herakles drachms. ${ }^{25}$ Of the 48 measured coins (in the BM and the Ashmolean, Oxford), some have a diameter of $14 \mathrm{~mm}$, but the great majority, 35 coins, are $15-$ $16 \mathrm{~mm}$. Seven are $17 \mathrm{~mm} .{ }^{26}$ The diameter of the young Herakles drachms varies from $14-18 \mathrm{~mm}$. Of the 36 measured coins two are $14 \mathrm{~mm}, 20$ are $15-16 \mathrm{~mm}$, twelve are $17 \mathrm{~mm}$ and two are $18 \mathrm{~mm}$. One can thus see a clear tendency towards larger and thinner flans in the earlier issue, a tendency which becomes stronger in the later one.

Both the obverse and the reverse motifs are the same in these two issues. On the reverses the ethnic is placed above the crab, and the name normally under the club.

There is also a similarity between this issue and Höghammar 2007, issue A9 (uncertain name), a Rhodian weight hemidrachm with the head of the young Herakles r./club ( $P l$. 7). ${ }^{27}$ The reverse of this coin shows some differences to the other coins in the issue, the motif consisting of just a club (no bow-in-case) is set in a shallow square incuse. The issue must be contemporary with the Koan and Kalymnian "Persic"/Micrasiatic issues which I connect with king Philip V of Macedonia's attack on Kos and Kalymnos in 201. This gives us a probable date of $c .200$ for this plinthophoric coin ${ }^{28}$ Should this be correct it is the earliest known coin of this type from this area and period.

\section{Differences}

Traits separating this issue from HI XII and XIII are the incuse on the reverse, the control letters and a different spelling of the ethnic. The whole issue is also characterized by its multiple internal links.

The shallow square plinthos (incuse) on the young Herakles drachms differentiates them from the 3 rd century drachms and hemidrachms with no incuse, and connects them to the 2nd century Asklepios/incuse silver. It is, however, important

\footnotetext{
25 He has kindly informed me that the photos in his volume are not exactly $1: 1$. They can thus not be used for measuring.

26 Diameter of drachms: $14 \mathrm{~mm}$ : five coins; $15 \mathrm{~mm}: 18$ coins; $16 \mathrm{~mm}: 17$ coins; $17 \mathrm{~mm}$ : seven coins.

27 Höghammar 2007, 80, 82-83, 85-92.

28 The name on this coin (Berlin 18205802) is difficult to determine. Stefanaki reads it as Lochos; I read the surviving letters as ]Or $\Lambda$ [. Imhoof-Blumer and Paton both read $\triangle \mathrm{OrO \Sigma}$ (Imhoof-Blumer, $Z f N 7$, 1880, 27, Kos no. 3; Paton \& Hicks 1891, p. 313, no. 146). Giannikouri and Stefanaki suggest a later date, either between 185/80-170 or first half of the 1 st century for this coin. The earlier date is based on the incuse which they, following Ingvaldsen, date to after $c$. 180, which I consider too late (see below). The later date mainly rests on arguments connected to the name Lochos (Giannikouri \& Stefanaki 2010, 463).
}

to point out that precursors of the plinthophoroic coins can be found in Koan early 3rd century silver. ${ }^{29}$

Control letters are unusual on Koan coins, and, as already noted, we do not, as yet, know their function. Of the 26 issues published by Ingvaldsen, only five show control letters, the two discussed here and HI VI and VII in silver and issue IX in bronze, dating to the later 4 th to early 3 rd century. ${ }^{30}$

The silver minted in the 3rd century does not have any control letters. They first reappear $c .200$ with the issues Höghammar 2007, A and C, which both have "A" and "K" "A" also appears on the Apollo/lyre hemidrachms and " $\mathrm{K}$ " on the Herakles/incuse drachms. On both the Höghammar 2007 issues and on the hemidrachms the control letters have the same position, low on the flan, below the name or the pictorial symbol. ${ }^{31}$

The silver issue with head of Asklepios/coiled snake in incuse published by Kroll in 1964, which I believe dates to the first half of the 2nd century, also has control letters. ${ }^{32}$ They are $\mathrm{A}, \Delta, \mathrm{E}, \mathrm{H}, \mathrm{A} \Sigma(?)^{33}$ and $\Pi \mathrm{I}$. The first three also appear on the two issues studied here. On the Asklepios/incuse silver the letters are normally situated low on the flan outside the incuse square.

The ethnic on the Herakles/incuse issue is spelled $\kappa \omega t \omega \nu$. On all Koan coins down to the very end of the 3rd century the ethnic is spelled $\kappa \omega \iota 0 v,{ }^{34}$ whereas almost all 2 nd century coins have the spelling $\kappa \omega \omega \omega \nu{ }^{35}$

29 In his 2002 dissertation Ingvaldsen (p. 42-43) states that the incuse on the early 3 rd century didrachms and tetradrachms, HI XI.1 and XIV.1, and the young Herakles/incuse drachms were made with the same type of die. The opinion of Requier is that only some coins in HI XIV show a shape which is close to the plinthophoric. When discussing this with Ingvaldsen in January 2013 he wrote to me that he now was of the same opinion as Requier. See also p. 280, n. 99.

30 Meadows dated HI III and IV to the 340 s, consequently HI VI and VII should be later. Meadows 2002, 238-240. Ingvaldsen very tentatively dated issue IX to somewhere in the period $c .330-250$. Ingvaldsen $2002,111-112,164$.

31 The control letters on the Herakles/incuse drachms are placed higher up, above the name of the magistrate.

32 Höghammar 2010b, 271-273.

33 On the obverse of coin MK 145 in Kos museum.

34 A few of the very latest 3rd century hemidrachms minted by Epinikos have the new spelling, namely three coins from $I G C H 1308$, NM, Athens, all struck from the same reverse die, HI no. 117, O33/R75 (=Athens 62), HI no. 124, O34/R*(Athens no. 69), and Athens no. 73 (not in Ingvaldsen's catalogue). Athens nos. 69 and 73 were struck from the same obverse die, different to that of Athens no. 62.

35 On Kos, in contrast to several other poleis, it seems as if there is a change in the spelling of the ethnic within a fairly short period of time. I will not discuss the exact meaning of the ethnic in its different forms. In this context it is the change itself which is of interest. 


\section{Discussion and summary}

The young Herakles/incuse issue differs markedly from the earlier groups in its ratio of coins to obverse dies. The bearded Herakles drachms have 206 coins to 34 obverse dies, a ratio of $6: 1$. The young Herakles/incuse issue has 44 coins to $23 \mathrm{ob}-$ verse dies, a ratio of $c .2: 1$, which strongly suggests that the original number of dies was larger.

As for the estimated original number of obverse dies (see Appendix), the calculations show that the minimum number was almost certainly higher than that of the bearded Herakles/crab drachms from the 3 rd century. This means that the present issue, if in all cases each identified die produced the same number of dies (something which is highly unlikely for any issue, but presumed here to make comparisons possible), was larger than the 3 rd century issue. ${ }^{36}$

Another difference concerns the interconnections between the different moneyers. The internal cross-links of the earlier issue are less numerous than those of the later. The bearded Herakles issue is more spread out in time and the dominant pattern is that of two moneyers coining together. Only at the end can we see multiple die-links comparable to those in the young Herakles/incuse issue. ${ }^{37}$

Five of eight moneyers are die-linked, Archias to both Aratos and Aristai(o)s and Patrokles to Diotimos. More than half of the moneyers in the issue are thus die-linked to one or more others. ${ }^{38}$ As far as we know, it was rare for an obverse die to be used over two or more consecutive years. ${ }^{39}$ The sharing of a die thus most probably means that the magistrates worked together, probably within a period of one year. ${ }^{40}$ The remaining

36 Ingvaldsen estimated the original number of dies for this issue to 36 (+/-less than 1) using Carter's simplified formula (Ingvaldsen 2002, $80-83,120)$.

37 Höghammar, 2013, 198-199, Table 1; Ingvaldsen 2002, 120.

38 As we don't have all the dies from the issues more die-links may well appear.

39 City-state issues are (to us) normally not clearly datable to any given year. Athens, however, is an exception. Mørkholm's results from 1983 show that only $4 \%$ of the obverse dies used for the Athenian "New Style" tetradrachms in the Late Hellenistic period were used for seven months or more. The dies for the contemporary drachms seem to have lasted somewhat longer: about $13 \%$ were used for seven or more months. Mørkholm also looked at three small 2nd century Ptolemaic mints on Cyprus. There, about $7 \%$ of the tetradrachm dies were used over three or more regnal years (Mørkholm 1983, 12-13). Some recently published mid-2nd century issues from Sidon, Tyre and Berytos also show that the practice of using the same obverse die over two or more years was rare. In Tyre eleven of $185(6 \%)$ and in Sidon five of 26 obverse dies (19\%) were used for two consecutive years (Iossif 2011, 214-216). In Berytos only one of 23 obverse dies (4\%) was used over two years (Sawaya 2005, 109.110). It is reasonable to conclude that, in the Hellenistic period, the large majority of the obverse dies were used within a period of one year.

40 Some Koan officials sat for six months, others for one year (Carlsson 2010, 226). We don't know the exact position of the Koan moneyers within the state apparatus. Did they form part of the "normal" magistra- three moneyers cannot be distributed over more than three years, and as they also have links to the die-sharing magistrates, they probably worked chronologically close to them. Should this be correct the issue must have been minted within a short period of time, probably not more than five to ten years.

In its technical details (weight, die-axis, diameter) the issue is similar to the preceding issue of drachms (HI XII) to which it is connected also by its type. The main type of both obverse and reverse (head of young Herakles $r$,/crab) is exactly the same as on the $3 \mathrm{rd}$ century hemidrachms. Other traits are the same as in other $c$. 200/2nd century issues as the control letters and the different spelling of the ethnic.

\section{THE APOLLO/LYRE HEMIDRACHMS (PLS. 4-6)}

$O b v$. Head of Apollo laureate right

Rev. Lyre, magistrate's name vertically left of lyre; ethnic, $\mathrm{K} \Omega \mathrm{I} \Omega \mathrm{N}$, vertically right of lyre ${ }^{41}$

\section{No. Obv/Rev Weight Axis Diam}

(g) (h) (mm)
$\mathrm{NIK} \Omega[\mathrm{N}$

1. $1 \mathrm{a} / 1$
1213 Paris,BN1232(=PHN224, Paris, $\mathrm{P}$ (aton), VS 1766). Pl. 4

\section{$\mathrm{A \Gamma H \Sigma IA \Sigma}$}

3. $1 \mathrm{~b} / 2$

1.08

12

E. Cahn 1931, cat. 71, no. 468 (VS 1768)

London BM, Kinns 19837-33-3. (VS 1767) Pl. 4

IEP $\Omega N$

$4.2 / 3$

1.16

1

\section{2}

Imhoof-Blumer. (VS 1758) Pl. 4

cies or did they form ad hoc "special commissions" appointed for a specific task (oil aip $\theta \dot{\varepsilon} v \tau \varepsilon \varsigma$ ), an institution that was frequently used on Kos? (Carlsson 2011, 224) At present, I lean more towards the second alternative for three reasons; firstly, the Koan state minted only sporadically in times of peace, secondly, a commission of moneyers could be appointed whenever there was need, and thirdly, the size of the commissioned group of officials could be varied for each occasion according to need. The ad hoc commissions formed a flexible system which well suited the needs of the Koan mint. It is, however, also possible that there was a regular magistracy that, whenever necessary, could cover the area of minting. But as this was a major task, it is less likely that it could be added on to other existing areas of responsibility. If the Koan moneyers were appointed as special commissions, they probably sat for a limited period of time. On finishing their task/term of office they would have been accountable to the demos or one of its organs, a normal procedure in Greek democracies. 41 All information on coins nos. 19, 29, 31, 34 and 41 was provided by V. Stefanaki. 
5. $3 / 4 \quad 1.65 \quad 12 \quad 13$ Berlin 18211760, acq. 1906 Löbbecke. (VS 1759) Pl. 4

6. $4 / 5 \quad 1.07 \quad 12 \quad 13$ London, $B M C 169(\mathrm{HI}$ 16a, VS 1760). Pl. 4

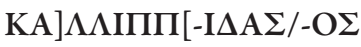

7. $4 / 6 \quad 1.23 \quad 12 \quad 12.5$ London, BMC $168(\mathrm{HI}$ 18a).Pl. 4

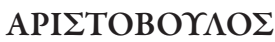
8. $5 / 7$
1.49
12
13 Paris, $\mathrm{BN} 1231$ (= $\mathrm{PH}$ N221, VS 1770).Pl. 4

\section{APXIA $\Sigma$}

9. $6 / 8$

1.40 VS 1729).Pl. 4

\section{ПАТРОК $\Lambda \mathrm{H} \Sigma$}

10. $7 / 9 \quad 1.39$

12

13

Löbbecke. (VS 1754) Pl. 4
11. $8 \mathrm{a} / 10 \quad 1.30$
1212 London,BMRobinson 1934- 3-12-27, IGCH 1320 (HI 14a, VS 1756). Pl. 4

12. $9 / 11$

1.43

12(?) 1

London, BM Robinson 1934-3-12-24, A beneath lyre, IGCH 1320 (HI 13a, VS 1755).Pl. 4

\section{APATO $\Sigma$}

13. $8 \mathrm{~b} / 12 \quad 1.30 \quad 12$

New York 1960.170.288

(HI 15a, VS 1757). Pl. 4

\section{API $\Sigma T A I O \Sigma$}

14. 8c/13 $1.26 \quad 1214$ London BMC 166 (HI 8a, VS 1748). Pl. 5

15. $8 \mathrm{~d} / 14 \quad 1.38 \quad 12 \quad 12$ Paris, BN 1230. Two countermarks on obverse. (VS 1747) Pl. 5

16. $10 \mathrm{a} / 15 \quad 1.49 \quad 12 \quad$ New York 1960.170 .289 (HI 10a, VS 1736). Pl. X

17. $10 \mathrm{~b} / 16 \quad 1.43 \quad 12 \quad$ New York 1940.206.4, (ex. Hirsch 3650c? HI 9a, VS 1734).Pl. 5

18. $10(?) / 17 \quad 1.39 / 4011 \quad 12$ Kalymnos, Archaeological Museum; Gargali, $N C$ 2009, no. 4, A beneath lyre(?). (VS 1731) Pl. 5

19. $10($ ?)/18 $1.57 \quad 12 \quad 11$ Myers, 5, 15-16/3, 1973,
20. $11 \mathrm{a} / 19 \mathrm{a} \quad 1.39 \quad 12$

21. $11 \mathrm{c} / 19 \mathrm{~b}(1.06) \quad 12$

22. $12 / 20$

1.25

23. $13 / 21$

no. 209; Hess 15/2, 1934, 465; Cahn 80, 27/2, 1933, 352. (VS 1730) Pl. 5

New York 1944.100.48493, Rhodes 1931, A beneath lyre, IGCH 1321 (HI 4b, VS 1745).Pl. 5

3 Oxford, Ashmolean, Milne 21/8, 1925 (HI 4a, Sotheby 1924/15/11, 68; Weber 6505), part of flan cut off, A beneath lyre. (VS 1746) Pl. 5

Oxford, Ashmolean, Milne 21/8,1925,(Zitelli, Rhodes 15/1/1925) A beneath lyre, (HI 5a, VS 1749). Pl. 5

London BMC 167, A beneath lyre (HI 12a, VS 1741).Pl. 5

24. $14 / 22 \quad 1.50 \quad 12 \quad$ New York 1944.100.48494, A beneath lyre, $I G C H 1321$ (HI 6a, VS 1735). Pl. 5

25. $15 \mathrm{a} / 23 \quad 1.27 \quad 12 \quad 14$ London, Rob. 1934-3-1226, A beneath lyre, $I G C H$ 1320 (HI 7a, VS 1744). Pl. 5

26. $15 \mathrm{~b} / 24 \quad 1.40 \quad 11 \quad 12$ Kalymnos, Archaeological Museum, Gargali, $N C$ 2009, no. 5. (VS 1739) Pl.

12 London 1979-1-1-599(HI

27. $16 / 25 \quad 1.56$ 3a, VS 1738, $S N G$ von Aulock 2763, Glendining 1951, 222 Coll. Cunningham). Pl. 6

28. $17 / 26 \quad 1.56 \quad 12 \quad 12$ London, BMC 165 (HI 11a, VS 1743). Pl. 6

29. $17 / 27 \quad 0.87$ of Fine Arts, 927 (VS 1732)

30. $18 / 28 \quad 1.48 \quad 11 \quad 12$ Winterthur 3622, Münzhandlung Basel 25, 13/1/ 40 , A beneath lyre (HI 2a, VS 1740)

31. $19 / 29 \quad 1.27$ Dewing 2394 (VS 1737, Glendining 13/11/1957, 160) 


\section{$\Theta] \operatorname{PA} \operatorname{SAN} \Delta[\operatorname{PO}$}

32. $11 \mathrm{~b} / 30 \mathrm{a} 1.55$

12

33. $8 \mathrm{e} / 30 \mathrm{~b} \quad 1.23$

34.

35

1.40

$\triangle$ IOTIMOE

36. $20 / 31$

\section{London, BM Rob 1934-3- 12-25, A beneath lyre, $I G C H$ 1320(HI 17a, VS 1751).Pl. 6}

1112 Berlin18211765,acq. 1852 , no. 10514, A beneath lyre. (VS 1752) Pl. 6 A.G. Malloy, XXVIII, 21/ 7/1989, no. 150 (VS 1753) 12(?)PH, N 222 (Karlsruhe (Im.), VS 1750)
1.46

\section{Private collection, UBS} 15/9/98, no. 266, K E vertically l. of (=below) name. (VS 1772) Pl. 6

\section{$\Lambda$ ЕҮКІППО}

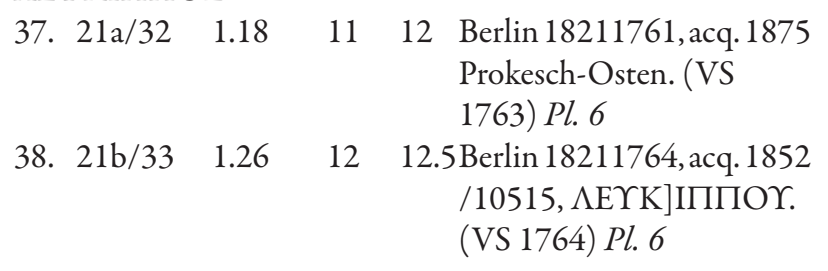

$[\mathrm{K}] \Lambda[\mathrm{E} \Omega] \mathrm{N} \Upsilon \mathrm{MI}[\Delta] \mathrm{A}[\Sigma(?)$
39. $1.37 \quad 12 \quad 14.5 S N G$ Copenhagen Caria 659 (Rollin) (no A below lyre). (VS 1762) Pl. 6

\section{ПAPMENI $\Sigma[\mathrm{KO} \Sigma$}

$\begin{array}{lllll}\text { 40. } 22 / 34 & 1.32 & 12 & 12 & \begin{array}{l}\text { Paris, } \\ \text { Pl. } 6\end{array}\end{array}$

\section{KAEYФANT $[\mathrm{O \Sigma}]$}

41. $23 / 35 \quad 1.47$

Bern, BHM, G 1591

(VS 1771)

\section{EYKPATOY}

42.

$\begin{array}{rl}1.321213 & S N G \text { München } 22, \text { no. } 523, \\ & \text { pl. 27. Acc. } 30968(\mathrm{HI} \\ & \text { 19a, VS 1765).Pl. } 6\end{array}$

.... $\mathrm{YHK}^{42}$
43. $24 / 36 \quad 1.37 \quad 12 \quad 11$ Paris, BN 1234, (.. ҮH $\Lambda \Omega$ ... PH N 227). (VS 1769) Pl. 6

42 Stefanaki reads the name as "Agesias?", but I cannot see it.

\section{No name discernible}

44.

1.18

45. $25 /$

1.20

6

14 Private collection (Agora coins = A. Metz bought on eBay 4 Dec. 2004, VS 1733). Pl. 6

Imhoof-Blumer. (VS
1774) Pl. 6

\section{Characteristics}

Both obverse and reverse types, head of Apollo laureate r./lyre, are new to Kos.

Estimated weight standard and weight distribution (Fig. 1b) The 41 coins for which weights are recorded range from $1.06-1.65 \mathrm{~g}$ (with an outlier at $0.86 \mathrm{~g}$ ). Twenty-eight (68\%) weigh between $1.20-1.50 \mathrm{~g}$. Six coins weigh $1.50 \mathrm{~g}$ or more. Allowing for weight loss due to wear I suggest that the weight standard of the issue was $1.60 \mathrm{~g}$.

\section{Die-axes and flan diameters}

Twenty-eight of the 37 coins studied have a $12 \mathrm{~h}$ die-axis, five are at $11 \mathrm{~h}$ and one at $1 \mathrm{~h}$. Two coins are at $6 \mathrm{~h}$ and one at $4 \mathrm{~h}$. The aim thus was a $12 \mathrm{~h}$ axis. The diameter of the $33 \mathrm{flans}$ measured varies from 11 to $14 \mathrm{~mm}$. Three are $11 \mathrm{~mm}, 18$ are $12 \mathrm{~mm}$, seven are $13 \mathrm{~mm}$, and five are $14 \mathrm{~mm}$. The main group of 25 coins thus comprises flans of $12-13 \mathrm{~mm}$.

An unusually large proportion of the reverses are struck partly off flan. Of the 29 coins for which I have information, 17 have part of their legend more or less off flan. ${ }^{43}$ Some of the obverse dies in the earliest group were also struck partly off flan. This is a sign of carelessness perhaps caused by a hurried production.

\section{The control letters (Fig. 2)}

At least 14, i.e. about a third, of the coins show a control letter or letters. The letter A appears on the coins of Archias, Patrokles, Aristaios (six coins) and Thrasyandros. The letters $\mathrm{K} \mathrm{E}$, a combination also found on the drachms, appear on the coin of Diotimos. The following names appear without a control letter: Nikon, Hieron (three coins), Kallippidas, Aristoboulos, Aratos, Patrokles (?), Aristaios (four coins), Leukippos, Kleonymidas and Parmeniskos. Aristaios thus minted

\footnotetext{
43 Another two also appear to be struck partly off flan, but they are so heavily worn that one cannot be certain. The moneyers appearing on coins with legends partly off flan are; Agesias, Aratos, Aristaios, Aristoboulos, Archias, Thrasyandros, Nikon, Parmeniskos and Patrokles.
} 
coins both with and without the control letter. This was possibly also the case for Patrokles. ${ }^{44}$

No clear pattern appears from this small sample. Some magistrates appear only with no letter; one, possibly two, appear both with and without a letter; some appear only with a letter. However, as we have so few coins for each name (except Aristaios), no firm conclusions can be drawn.

\section{The ratio of names to coins and obverse dies}

The number of obverse dies is 25 . Sixteen full names can be read, ${ }^{45}$ six of which also appear on the young Herakles/incuse

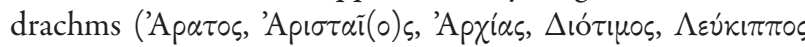

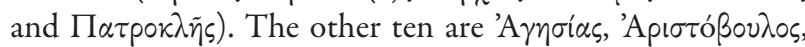

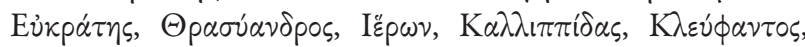

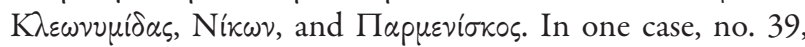
the name Kleonumida is possibly in the genitive (or the final sigma may simply be invisible).

The figures for coins and obverse dies are as follows $(\mathrm{n}=$ number of coins and $\mathrm{d}=$ number of observed dies):

$\begin{array}{lll}\text { Name } & n & d \\ \text { Nikon } & 1 & 1 \\ \text { Agesias } & 2 & 1 \\ \text { Hieron } & 3 & 3 \\ \text { Kallipp- } & 1 & 1 \\ \text { Aristoboulos } & 1 & 1 \\ \text { Archias } & 1 & 1 \\ \text { Patrokles } & 3 & 3 \\ \text { Aratos } & 2 & 1 \\ \text { Aristaios } & 18 & 1 \\ \text { Thrasyandros } & 3 & 2 \\ \text { Diotimos } & 1 & 1 \\ \text { Leukippos } & 2 & 1 \\ \text { Kleonymidas } & 1 & 1 \\ \text { Parmeniskos } & 1 & 1 \\ \text { Kleufantos } & 1 & 1 \\ \text { Eukrates } & 1 & 1\end{array}$

All dies are represented by either one single or just a few coins. Eleven magistrates have one coin to a die.

\section{Links between moneyers (Figs. $5 \& 6$ )}

Sixteen different magistrates appear on the coins (on three coins the name cannot be read). Using the same criteria as for the drachms, plus that of the same stylistic sub-type on ob- verse motif, most can be linked in different ways. Two groups appear, group 1 (Fig. 5) and group 2 (Fig. 6). Individuals in the two groups also have separate links to moneyers outside them. As with the drachms just about all coins and magistrates are linked to others in one way or another. These linkages indicate that also this issue was minted within a short period of time, as already noted by Ingvaldsen. ${ }^{46}$ The exact internal order is not easy to distinguish, but eight moneyers shared obverse dies with one or more others. ${ }^{47}$ For those linked by the same die a relative order can be established, except for the coins of Hieron and Kallippidas struck with the die O4 (see below). Koan 3rd century silver issues were normally the responsibility of a pair of moneyers, as Ingvaldsen has shown. The crosslinks apparent in this issue suggest that, at least for part of it, more than two magistrates minted simultaneously. The second group is very tight showing multiple links.

The die-links: Four obverse dies were used by more than one magistrate; O1, O4, O8 and O11. Three were used by two different magistrates and one, $\mathrm{O} 8$, was used by four. The order of use is based on the wear of the die as indicated by the wear of details closest to the flan of the coins. The die O1 was first used by Nikon (O1a) and then by Agesias (O1b). The coins with names of Hieron and Kallippidas (O4) are so worn that it is not possible to determine their relative order. The die $\mathrm{O} 8$ was used first by Patrokles (O8a), then Aratos (O8b), followed by Aristaios (O8c, d) and finally by Thrasyandros (O8e). O11 was first used by Aristaios (O11a), later by Thrasyandros $(\mathrm{O} 11 \mathrm{~b})$, and then again by Aristaios (O11c).

The order of the remaining magistrates cannot be established, and whether Nikon and Agesias, Hieron and Kallippidas were earlier or later than the other group of four linked names cannot be determined with certainty. I have placed them before group 2 in the list, as I think there are indications that they might be earlier. I will return to this below.

Same control letter: Some of the coins of Archias, Patrokles, Aristaios and Thrasyandros share the control letter $\mathrm{A} \cdot .^{48}$ As we have only one, or, at most, a few coins from all moneyers except Aristaios, few firm conclusions can be drawn from this. The letter A is, however, one more link connecting Patrokles, Aristaios and Thrasyandros who also used the same obverse die.

\footnotetext{
46 Ingvaldsen 2002, 156.

47 Nikon, Agesias, Hieron, Kallipp/-idas or -os, Patrokles, Aratos, Aristaios and Thrasyandros.

48 Coins 9, 12, 18, 20-25, 30, 32-33.

44 On coin no 11 the bottom of the lyre is at the edge of the flan. Any control letter on the die was thus off flan.

45 Another two coins show letters which do not agree with the known names, but cannot be read fully.
} 


\begin{tabular}{|l|l|l|l|l|l|l|}
\hline \multicolumn{2}{|l|}{ Internal links } & \multicolumn{2}{l|}{ External links } \\
\hline Name & $\begin{array}{l}\text { Die } \\
\text { (coin } \\
\text { no. })\end{array}$ & $\begin{array}{l}\text { Control } \\
\text { letter } \\
\text { (coin no. })\end{array}$ & $\begin{array}{l}\text { Letter cutter } \\
\text { (luster } \\
\text { (coin no. })\end{array}$ & $\begin{array}{l}\text { Iconographic) } \\
\text { Stylistic group } \\
\text { (coin no. })\end{array}$ & $\begin{array}{l}\text { In IGCH } \\
1320 \\
\text { (coin no. })\end{array}$ & $\begin{array}{l}\text { Name also } \\
\text { in PH 10 }\end{array}$ \\
\hline Nikon & $1 \mathrm{a}(1)$ & & $\mathrm{A}(1)$ & $\mathrm{A}(1)$ & & $\mathrm{x}$ \\
\hline Agesias & $1 \mathrm{~b}(3)$ & & & $\mathrm{A}(3)$ & & $\mathrm{x}$ \\
\hline Hieron & $4 \mathrm{a}(6)$ & & $\mathrm{A}(4,5)$ & $\mathrm{A}(4-6)$ & & $\mathrm{x}$ \\
\hline Kallipp[idas] & $4 \mathrm{~b}(7)$ & & $\mathrm{A}(?)(7)$ & & $\mathrm{x}$ \\
\hline Aristoboulos & & & $\mathrm{A}(8)$ & & $\mathrm{x}$ \\
\hline Patrokles & & & $\mathrm{A}(10)$ & $\mathrm{A}(10)$ & & \\
\hline
\end{tabular}

Fig. 5. Apollo hemidrachms. Internal and external links, group 1 .

\begin{tabular}{|c|c|c|c|c|c|c|}
\hline \multicolumn{5}{|l|}{ Internal links } & \multicolumn{2}{|c|}{ External links } \\
\hline Name & $\begin{array}{l}\text { Die } \\
\text { (coin no.) }\end{array}$ & $\begin{array}{l}\text { Control } \\
\text { letter } \\
\text { (coin no.) }\end{array}$ & $\begin{array}{l}\text { Letter cutter } \\
\text { cluster } \\
\text { (coin no.) }\end{array}$ & $\begin{array}{l}\text { Iconographic/ } \\
\text { stylistic group } \\
\text { (coin no.) }\end{array}$ & $\begin{array}{l}\text { In IGCH } \\
1320 \\
(\operatorname{coin} \text { no. })\end{array}$ & $\begin{array}{l}\text { Name } \\
\text { also } \\
\text { in PH } 10\end{array}$ \\
\hline Archias & & $\mathrm{A}(9)$ & B (9) & $\mathrm{B}(9)$ & $\mathrm{x}(9)$ & \\
\hline Patrokles & $8 a(11)$ & $\mathrm{A}(12)$ & $\begin{array}{l}\mathrm{B}(12) \\
\mathrm{C}(11)\end{array}$ & $\mathrm{C}(11,12)$ & $\mathrm{x}(11,12)$ & \\
\hline Aratos & $8 \mathrm{~b}(13)$ & & $C(?)(13)$ & $\mathrm{C}(13)$ & & $\mathrm{x}$ \\
\hline Aristaios & $\begin{array}{l}8 c, d \\
(14,15) \\
11 a, c(20,21)\end{array}$ & A $(18,20-25,30)$ & $\begin{array}{l}\mathrm{B}(16,18,27) \\
\mathrm{C}(23,24)\end{array}$ & $\begin{array}{l}\mathrm{B}(16,17,23-27) \\
\mathrm{C}(20-22)\end{array}$ & $x(25)$ & \\
\hline Thrasyandros & $\begin{array}{l}8 \mathrm{e}(33) \\
11 \mathrm{~b}(32)\end{array}$ & $\mathrm{A}(32,33)$ & $\mathrm{C}(32,33)$ & $C(32)$ & $x(32)$ & \\
\hline
\end{tabular}

Fig. 6. Apollo hemidrachms. Internal and external links, group 2.

Same reverse die-cutter ${ }^{49}$

Cluster A: This cluster is characterized not only by stylistic criteria, but also by an incorrectly cut letter. Several dies have a distinctive reversed $n u$ with an oblique stroke starting low on the left vertical stroke and ending high on the right one. This can be seen on coins 1 (Nikon), 4, 5 (Hieron), 8 (Aristoboulos), 10 (Patrokles), and probably also on 7 (Kallipp[-idas/os), although the heavy wear of the last makes it difficult to be certain. On the basis of the shape of the other letters, this group can be divided into two subgroups. In one, consisting

49 As we are here dealing with a series issued within a short period of time and individual traits and mistakes are likely to have been the work of a single cutter, stylistic analysis can be expected to produce significant results. See also p. 289. of nos. 1, 4, 7 and 8 , the omega is mostly closed and the upper part of the half-circle is extremely thick. It is just about the same size as the other letters in the ethnic. The vertical stroke of the iota is thick and ends in thick bars. These dies must have been made by the same hand. In the second group, nos. 5 and 10 , the shape of the omega is somewhat different. A separate horizontal bar closes the bottom, but is not directly connected to the ends of the curved line which is rather thin all the way round. The letter kappa is clearly visible only on two coins, 1 and 10 . The vertical stroke is long and goes below the bottom line of the other letters on both. Probably all dies with the reversed $n u$ were made by the same engraver.

Cluster B: The reverses of coins 9 (Archias), 12 (Patrokles) have closely similar stylistic traits. The dots ending the letter strokes are large and form the dominating feature of several 
letters, for instance eta, sigma and tau. Coins 16,18 and 27 (Aristaios) should also belong to this group, made by the same die-cutter.

Cluster C: The similarities in the lettering of coins $11(\mathrm{~Pa}-$ trokles), 17, 20, 23, 24 (Aristaios), and 32, 33 (Thrasyandros) suggest that they were cut by the same engraver. The letters are fairly carelessly executed. The omega is big and has a wide open horseshoe shape ending in dots. Coin 13 (Aratos) is also very close in style and may well have been cut by the same engraver. Groups B and C both have distinct dots at the end of the letter strokes, but in group B they are so conspicuous as to dominate individual letters.

Cluster D: The lettering of the ethnic on coins 36 (Diotimos) and 37 (Leukippos) shows close similarities. The kappa has a long vertical stroke ending below the bottom line of the other letters and runs slightly obliquely to the left, "opening" upwards. The omega is open with long horizontal strokes ending either in thick dots or thick short hastae. The letter iota leans slightly to the right and the $n u$ is wide. The similarities are so strong that I consider the two dies to be made by the same engraver.

\section{Appearance in the same hoard}

Coins with the names Archias, Patrokles, Aristaios and Thrasyandros, as well as Aratos, appear in IGCH 1320 (Aratos only on the incuse drachms).

\section{Same stylistic sub-type on obverse motif $f^{30}$}

There are three clearly distinguishable stylistic/iconographic sub-types of the Apollo head. One displays Late Classical/ Hellenistic facial features, combined with loose hanging locks around the neck. ${ }^{51}$ The features of these faces are more irregular than those in a high-classicizing style which are characterized by heavy features, for instance a round prominent chin and full cheeks. ${ }^{52}$ The classicizing face can be combined with either loose hanging locks around the neck (second subtype) ) $^{53}$ or two twirled curls (third subtype). ${ }^{54}$ The last combination is thus distinguished by an iconographic trait, its hair-style. It shows two long and thick tightly twirled curls which hang down from the ear to the shoulder. The engraving of the Late Classical/Hellenistic-style group is generally of lower quality than that of the classicizing groups.

\footnotetext{
50 The designations of style are not used in order to determine chronology. They merely describe the different styles used by the engravers.

51 Late Classical/Hellenistic style; nos. 1, 3-8, 10, 37, 38, 40, 43.

52 On a few coins the face shows a transitional classicizing-Late Classical/Hellenistic style.

53 Classicizing style and loose locks; nos. 9, 16, 17, 23-27.

54 Classicizing style and long twirled curls; nos. 11-15, 20-22, 32, 36, 40,45 .
}

The magistrates placed first on the list appear on coins with the Late Classical/Hellenistic-style features. The cutting is of fairly poor to poor quality. With a few exceptions, ${ }^{55}$ the coins of the four magistrates connected by the same obverse die (Patrokles, Aratos, Aristaios and Thrasyandros) have the classicizing face, either with loose hanging locks or with the long twirled curls. The cutting is generally of higher quality. The coins listed after Thrasyandros show either a classicizing face with twirled curls, or a Late Classical/Hellenistic style face.

\section{The groups-discussion and conclusions}

Eight of 16 magistrates are die-linked, Nikon and Agesias, Hieron and Kallipp[-idas/-os], Patrokles, Aratos, Aristai(o)s and Thrasyandros, and, again, Aristai $(\mathrm{o}) \mathrm{s}$ and Thrasyandros. As we appear to have only part of the issue, more die-links are to be expected.

Certain coins minted by Nikon, Hieron, Aristoboulos, Patrokles and probably also Kallipp[-idas/-os] in the issue of hemidrachms show legends with a reversed N. Such a mistake would almost certainly have been made by one die-cutter only. The reversed $\mathrm{N}$ thus shows that all four (or five) magistrates most likely used the services of the same die-cutter.

These two linkages in the two issues, to which others can be added, indicate that the magistrates responsible were active within a short period of time.

One group of magistrates is formed by Nikon, Agesias, Hieron, Kallippidas, Aristoboulos and Patrokles. The pairs Nikon and Agesias, and Hieron and Kallippidas share obverse dies $\mathrm{O} 1$ and $\mathrm{O} 4$ respectively. Nikon, Hieron, Patrokles, Aristoboulos, and perhaps also Kallippidas, issued coins whose reverse dies were cut by the same die-engraver (cluster A with a reversed $\mathrm{N}$ ). All six issued coins with the same obverse subtype, a Late Classical/Hellenistic style Apollo head, generally poorly cut. Coins with this sub-type were also issued by Leukippos and Kleonymidas. In this group only one name, Patrokles, recurs on the drachms. He is also, in this group, the only moneyer represented in $I G C H$ 1320. All the names but Patrokles appear in the inscription $\mathrm{PH} 10$, three both as donor and patronymic, Agesias just as a donor, and Nikon just as a patronymic. ${ }^{56}$

A second group of five magistrates is very closely knit, sharing even more links than the previous group. They are Ar-

\footnotetext{
55 Patrokles on coins with both the classicizing (nos. 11, 12) and the Late Classical/Hellenistic (no. 10) face-type. Aristaios appears on a coin with a face in a transitional style.

56 Agesias PH 10b25, c4; Hieron PH 10b63; Kallippidas PH 10c10; Aristoboulos PH 10d48; Nikon PH 10c21.
} 
chias, Patrokles, Aratos, Aristaios ${ }^{57}$ and Thrasyandros. These, together with Aristandros, are the names which appear on the coins in $I G C H 1320$ (Aratos and Aristandros only on the incuse drachms). All but Archias shared the same obverse die (O8). All but Aratos used the same control letter, namely, A. The magistrates Archias, Patrokles and Aristaios(?) issued coins whose reverse dies were cut by one engraver (cluster B). Another set of coins, also cut by one engraver, was produced by a slightly different combination of magistrates; Patrokles, Aristaios and Thrasyandros (cluster C). The lettering style on the two groups is quite close, and they were perhaps cut by the same engraver. All but Archias issued coins with the same obverse subtype (a well-cut classicizing face with two twirled curls). Archias and Aristaios minted coins with a wellcut classicizing face and loose hanging locks. ${ }^{58}$ In group 2 four names recur on the drachms, Archias, Patrokles, Aratos and Aristaios. These moneyers are also represented in IGCH 1320. Only one of the names, Aratos, appears in PH 10.59

The first group is not as tightly linked as the second. The magistrates in it may all have worked together, but it is equally possible that they worked in pairs immediately following one another. The only reasonable conclusion to draw about the second group is that they all worked together. We have seen that four of them shared the same die (O8), and that another die (O11) was used alternately by Aristaios and Thrasyandros. Other links can be added. Patrokles appears in both groups, suggesting that there is no chronological gap between them.

From this pattern I conclude that the issue was minted within a very short period. We can also see that at least one, perhaps two, group/s of five (possibly more) magistrates worked simultaneously. Five of the six names in the first group with poorly carved motifs, Patrokles being the exception, appear in PH 10 dating to 201/0. The same five names also appear only on the hemidrachms. Possibly almost all the coins minted by the magistrates in the first group were produced before the drachms were minted, but there could be other explanations for this phenomenon. Four of the six names which do not belong to either group appear in PH 10, two of them, both rare, Kleufantos and Leukippos, just as patronymics. ${ }^{60}$

\footnotetext{
57 Three coins, all with the name Aristaios, were found in graves: drachm no. 14 (on Kos) and hemidrachms nos. 18 and 26 (on Kalymnos).

58 In the issue of drachms, the repeated links between Archias and Aristaios (alternate use of the same die, O3; same control letters, $\mathrm{KE}$; appearance in $I G C H$ 1320) and between Archias and Aratos (use of same die, O6; appearance in IGCH 1320) secures the close connection between Archias and the other four magistrates.

$59 \mathrm{PH} 10 \mathrm{c} 58, \mathrm{c} 81$.

60 Eukrates PH 10c5; Kleufantos PH 10c57-58; Leukippos PH 10b2; Parmeniskos PH 10a56, b1, b66, d8. As Kleufantos and Leukippos both are rare names on Kos, occurring fewer than ten times in the PHI database of Greek inscriptions (20120809, and no new occurrence in $I G$
}

Should the two patronymics refer to the same persons as the homonyms on the coins, then it is highly unlikely that they, as fathers of grown men in 201/0, would have been active 20 30 years later. Patrokles appears in the second group, on the drachms and in $I G C H 1320$. This group, with well carved motifs, is linked to both drachms and the hoard by four names. There is thus a strong connection between the second group and both the drachms and the hoard, not apparent for the first group. Only one name in the second group occurs in PH 10. For this reason I have placed the names in the first group before those of the second.

It is also interesting to note that six of the 18 known names appear in father-son relations dating c. 200/early 2nd century: Aratos, son of Kleufantos (PH 10c58), Parmeniskos, son of Hieron (PH 10b2, Höghammar 1993, 65) and Thrasyandros, son of Agesias (Segre 1993, ED 146, Pugliese-Caratelli 1963/64, XXVI B.II.57). ${ }^{61}$ The patronymics Hieron and Agesias occur in the first group, and the names of their sons, Parmeniskos and Thrasyandros, occur among the names which do not belong to either of the two groups, as does the third patronymic, Kleufantos. The name of his son, Aratos, occurs in the second group. ${ }^{62}$

The group 2 hemidrachms were most probably issued together with the incuse drachms as four names reappear in the two groups. In group 1 only Patrokles, also coining in group 2 reappear on the drachms.

\section{A comparison with other Koan silver issues (Fig. 7)}

The issue of the Apollo hemidrachms can be compared to the 3 rd century issue of young Herakles/crab, club hemidrachms which ceased being minted c. 200. ${ }^{63}$ Ingvaldsen lists 261 coins and 39 obverse dies for this issue. ${ }^{64}$ Here 45 coins and 25 obverse dies are listed for the Apollo hemidrachms.

XII.4.1), the conclusion that they refer to the same individuals is probable. See also p. 288, n. 170.

61 Habicht dated Segre 1993 ED 146 to c. 200 (Habicht 2004, 65). Compare Peisistratos and Kleuphanes on the Kalymnian coins (Höghammar 2007, 91-92) whose names also appear in a father and son combination in one Kalymnian inscription, Segre 1944-1945, no. 85.6, dating c. 200. Another Koan pair, Kallippidas, son of Aristandros in Segre, 1993 ED 230, dates to the 1st century AD.

$62 \mathrm{PH} 10 \mathrm{c} 58$. The name also appears on line $\mathrm{c} 81$, there as the son of Makareus.

63 For the dating see Höghammar 2013, 219-220. There is another issue of hemidrachms dating to 201-200, the young Herakles/club, bow-in-case issue, Höghammar 2007, A. Only nine examples are known, five of them extremely light, below $0.90 \mathrm{~g}$. Some could conceivably be quarter-drachms, but it would be almost impossible to distinguish a light hemidrachm of c. $1.10 \mathrm{~g}$ from a heavy quarter-drachm of $c .0 .80 \mathrm{~g}$, as they all have exactly the same motifs on both obverse and reverse.

64 Ingvaldsen 2002, 123, 125. 


\begin{tabular}{|c|c|c|}
\hline Feature & Herakles/crab, club hdr & Apollo/lyre hdr \\
\hline & \multicolumn{2}{|c|}{ Similarities } \\
\hline Weight spread & $\begin{array}{l}1.20-1.49 \mathrm{~g}, 89 \%(228 \text { coins }) \\
1.50 \text { g or more, } 4 \% \text { ( } 11 \text { coins })\end{array}$ & $\begin{array}{l}1.20-1.49 \mathrm{~g}, 68 \%(28 \text { coins }) \\
1.50 \mathrm{~g} \text { or more, } 12 \%(6 \text { coins })\end{array}$ \\
\hline $\begin{array}{l}\text { Estimated weight } \\
\text { standard }\end{array}$ & $1.60 \mathrm{~g}$ & $1.60 \mathrm{~g}$ \\
\hline Normal die axis & $12 \mathrm{~h}$ & $12 \mathrm{~h}$ \\
\hline \multirow[t]{2}{*}{ Diameter } & $12-13 \mathrm{~mm}$ (13 coins) & $\begin{array}{l}12-13 \mathrm{~mm}(25 \text { coins }) \\
14 \mathrm{~mm} \text { ( } 5 \text { coins })\end{array}$ \\
\hline & \multicolumn{2}{|c|}{ Differences } \\
\hline Motif & Head of Herakles/crab, club & Head of Apollo/lyre \\
\hline Ethnic & $\mathrm{K} \Omega \mathrm{ION}$, on a few coins $\mathrm{K} \Omega \mathrm{I} \Omega \mathrm{N}$ & $\mathrm{K} \Omega \mathrm{I} \Omega \mathrm{N}$ \\
\hline Control letter & - & A, K E \\
\hline Placing of legend & horizontal & vertical \\
\hline
\end{tabular}

Fig. 7. A comparison of the young Herakles/crab, club and the Apollo/lyre hemidrachms.

\section{Similarities}

As with the drachms the technical details parallel those of the previous 3 rd century issue, i.e. the weight, the die-axis and the diameter are basically the same.

The weights of the young Herakles/crab, club hemidrachms presented by Ingvaldsen show that 228 of the 256 weighed coins, $89 \%$, weigh $1.20-1.49$ g. Eleven coins, $4 \%$, weigh $1.50 \mathrm{~g}$ or more. ${ }^{65}$ This can be compared with the 28 coins, $68 \%$, of the Apollo hemidrachms weighing between $1.20-1.49 \mathrm{~g}$ and the six coins, $12 \%$ weighing $1.50 \mathrm{~g}$ or more. The spread is just about the same in both issues, with a peak at $1.30-1.39 \mathrm{~g}$ and a gradual decrease in the number of coins which are either lighter or heavier. Both issues also have a number of coins (eleven and six respectively) weighing 1.50 $\mathrm{g}$ or more. I agree with Ingvaldsen that the estimated weight standard of the two issues was the same, though I suggest that it was fractionally higher than the $1.50 \mathrm{~g}$ proposed by him, i.e. $1.60 \mathrm{~g}$.

The die-axis of the young Herakles/crab, club hemidrachms is normally $12 \mathrm{~h}$. Altogether 220 coins have a $12 \mathrm{~h}$ or near- $12 \mathrm{~h}$ axis. ${ }^{66}$ Some variations are at $6 \mathrm{~h}$ or $10 \mathrm{~h}$. The pattern is the same for the Apollo/lyre issue where 34 of the 37 coins with known axis are at or near $12 \mathrm{~h}$, and occasionally $\mathrm{a} 4 \mathrm{~h}$ and $\mathrm{a} 6 \mathrm{~h}$ axis occur.

Ingvaldsen does not report diameters and I have this information only for 14 young Herakles/crab, club hemidrachms,

65 Ingvaldsen 2002, 376.

66144 coins are at $12 \mathrm{~h}$ and another 76 at $11 \mathrm{~h}$ or $1 \mathrm{~h}$. Ingvaldsen 2002 , 264-277. (nine in the British Museum, four in Athens and one in Stockholm): 13 have a diameter of $12-13 \mathrm{~mm} .{ }^{67}$ Twenty-five of the 33 measured Apollo hemidrachms also have a diameter within that range, but five are $14 \mathrm{~mm}$. It seems that most coins in both issues measure $12-13 \mathrm{~mm}$, but with a tendency to a larger flan in the later issue.

\section{Differences}

More new features appear on the hemidrachms than on the drachms. The most obvious novelty are the motifs, but the form of the ethnic, the introduction of control letters and the vertical placing of the legends also differentiate this issue from the 3 rd century hemidrachms.

The types of both obverse and reverse are new to Kos: profile head of Apollo laureate turned right/lyre.

The later form of the ethnic is used on this issue. On a few of the very last $3 \mathrm{rd}$ century hemidrachms minted by Epinikos the new form can also be seen.

On all Koan coins from the later 4th century down to this issue legends were placed horizontally, the ethnic above and the name below the main reverse motif. Here the legends are vertical, the ethnic right of the lyre and the name to the left. As for the control letters on the hemidrachms see the discussion on the drachms.

\footnotetext{
67 Diameter; $11 \mathrm{~mm}$ - one coin, $12 \mathrm{~mm}$ - seven coins, $13 \mathrm{~mm}$ - six coins.
} 


\section{The Kalymnian connections}

Two names, present in both issues, may belong to Kalymnians (now Koan citizens) as they occur more frequently, if at all, in Kalymnian inscriptions. The corpus of Koan inscriptions is much larger than that of Kalymnian inscriptions, and so one would expect there to be more Koan entries if the name was equally common on both islands. The name of Aristaios appears only in one (early imperial) Kalymnian inscription, ${ }^{68}$ and that of Diotimos appears on eleven occasions in Kalymnian inscriptions, most dating to the 3 rd century or c. 200, as compared to one (possibly two) appearances in Koan inscriptions. $^{69}$

The obverse shows a head of Apollo and the reverse motif can be compared to that of several of the Kalymnian issues from $c .200$ showing a lyre. ${ }^{70}$ The choice of head of Apollo/lyre as motifs, the vertical placing of the legends, as on the Kalymnian coins, and the fact that some of the moneyers responsible for these issues very likely were Kalymnians is probably significant. The choice of type on the coins was regarded as a matter of public importance and the introduction of the Apollo/ lyre types must be interpreted in this context. ${ }^{71}$ Apollo was the principal god on Kalymnos and his appearance on Koan coins in the period c. 200-170 is likely to have something to do with the reincorporation of Kalymnos into the Koan state in 201/0. It would also acknowledge the contribution of the Kalymnians, now Koan citizens, and their main god, in the war against Philip V (201-197). ${ }^{72}$

68 The Aristaios in the Koan funerary inscription Herzog 1899, no. 182 , is a foreigner.

69 http://epigraphy.packhum.org/inscriptions/ (2011-10-19). Aristaios, Segre 1944-1945, no 178; Diotimos, Kalymnos, Segre 1944-1945, nos. 3, 58, 85 (five entries), 102, 130B, C, D (three entries); Kos, Segre 1993 , ED 233 b (dated to the 2nd century BC). PH 10c69 is a Kalymnian, SEG 36:758 is not Koan, and Klee 1918.8.II is of unknown nationality. An inscription from Samothrace gives a list of mystai thought to be from Kos which includes a Diotimos, son of Diotimos; the inscription is dated to the 2 nd century BC (Salviat, BCH 86, 1962, 275-278 no. 4.3); when Koan names could belong to men living either on Kalymnos or on Kos.

70 Höghammar 2010a.

71 When writing about local reverse types on coins from western Asia Minor during the imperial era, Robert connects the choice of motives and details with information on local cults transmitted to us by Quintus of Smyrna and by Nonnos. His conclusion is that the types on the coins and the representation in all its details closely correspond to local legends which are particular to each polis. That is "a large group of images can only be explained through the particular circumstances of a certain polis; cults, festivals, heroic and divine legends, traditions and inventions on the foundation and the parentage, ..." etc (Robert 1967, 102). Meadows points out "that cities did value the ability to choose and use their own designs." He also points out that the choice of national types was "an important function of the men charged with their production" (Meadows 2001, 59).

72 See also below pp. 291-293. The choice of a certain type could be due to economic or political reasons. Here I consider the reason to be political as this issue circulated only within Kos.

\section{Discussion and summary}

Also this issue differs greatly from earlier Koan issues in its ratio of coins to obverse dies. The young Herakles hemidrachms from the 3 rd century (HI XIII) with 263 coins and 39 dies have a coin:obverse die ratio of 7:1 whereas that of the Apollo/lyre hemidrachms with 44 coins is just below 2:1, strongly suggesting that the original number of dies was considerably larger. The estimates presented by Esty in the Appendix show that the original number of dies was most likely at least 40 and probably higher. Ingvaldsen estimates the original number of dies for issue XIII to have been 41 (+/- less than 1) using Carter's simplified formula. Esty's results show that the Apollo/lyre issue with most likely more than 40 dies in all probability was larger than the 3 rd century issue.

The hemidrachms show indications of careless production, possibly due to having been minted in hurried conditions. More than half of the reverses were struck partly off flan. By contrast, on the drachms such a carelessly struck reverse appears only once.

The large majority of the moneyers belong to one of two groups which are linked by the name of one man. The second group is tightly linked and all the moneyers in it must have worked together. As the two groups are connected the whole issue must have been issued within a short period of time. As far as we know, the life of an obverse die was normally one year or less (see n. 39), thus the whole issue should have been minted within less than ten years.

As it is the second group which appears to have been coined together with the drachms, perhaps the mint started issuing the hemidrachms and then, shortly afterwards, also the drachms. We need to be careful with such conclusions however, as we appear to have far from all original dies.

There is in this issue a clear Kalymnian connection which probably has to do with the common struggle of Kalymnians and Koans against Philip V of Macedonia c. 200.

When compared to other 3 rd and 2 nd century national silver, it is clear that these two issues are transitional in character. They retain certain 3 rd century traits, mostly of a technical character, but they also show several 2 nd century features.

\section{The dating of the issues}

Ingvaldsen based his discussion of the drachms on 28 coins (here 44), 16 obverse dies (here 23) and five names (here eight), and the hemidrachms on 20 coins (here 45), 14 obverse dies (here 25) and six names (here 16). The much enlarged body of names makes a difference when comparing the issues with other 2 nd century issues.

As noted, the ratio of coins to obverse dies, roughly 2:1, shows that we probably have only a small part of the original 
output and can expect new data to emerge when more coins appear. This raises the matter of how many coins we have of these two issues as compared to the slightly earlier issues of drachms and hemidrachms on the Rhodian weight standard, HI XII and XIII, and the (partly parallel?) succeeding issue of Asklepios/incuse silver. There is a considerable difference between the issues in the number of known coins. ${ }^{73}$ Among scholars presently working on the Koan mint there is a consensus that the issues discussed here were minted within a short period of time, no more than ten years, possibly fewer than five. ${ }^{74}$ When I compare the numbers of obverse dies and coins I will therefore do it with what I have called "the late groups" of bearded Herakles drachms and young Herakles hemidrachms. These groups were probably minted between $c$. 210-200, a period of about the same length as that presumed for the two later issues. ${ }^{75}$ The estimated period of time within which the later Asklepios/incuse silver issue was minted is about 50 to 60 years in Kroll's 1964 study, but he stresses that it was more compact and did not span the entire period. ${ }^{76} \mathrm{No}$ study has been made on the detailed chronology of the issue, so I will therefore use the numbers for the whole series when referring to it.

The late group of bearded Herakles drachms, HI XII, presently contains 23 obverse dies and 117 coins; $;^{77}$ the young Herakles issue has the same number of dies, but only 44 coins. As for the hemidrachms, the late group in the earlier issue comprises 32 obverse dies and 219 coins $;^{78}$ the Apollo hemidrachms have 24 obverse dies and only 45 coins. The number of extant coins belonging to the later issues is thus comparatively small, and new coins rarely appear on the market. As for the Asklepios/incuse silver issue of the second century, 134 obverse dies and 370 coins are known. ${ }^{79}$ Again there are relatively few coins per die, but new coins from this issue appear regularly on the market and their number is growing steadily. It is clear that we have a much smaller number of coins from the young Herakles/incuse and Apollo issues than could be expected when compared with the preceding (and succeeding) issues. What could be the reason for this? If the original output of coins was small one would expect fewer obverse dies. If as many, or more, coins were minted as in the late group of

\footnotetext{
73 The search for coins belonging to these two issues has been as thorough as that for the other issues compared to it. The difference in numbers is thus not due to less efficient searching.

74 Ingvaldsen 2002, 156, 160, 164; Stefanaki, information in e-mail.

75 For a discussion of the "late groups" see Höghammar 2013, 202-203.

76 Kroll 1964, 85. Presumably the minting of it went on for several decades. With all the new coins now known, the issue needs to be restudied in detail.

77 See also Höghammar 2013, 202-203.

78 See also Höghammar 2013, 202-203.

79 Stefanaki 2012, 266-280.
}

Herakles drachms, then the difference in the number of extant coins could be due to a short period of circulation caused by withdrawal of the coins from the market when, as I presently believe likely, the state wished to introduce the Asklepios/incuse coinage. ${ }^{80}$ This large issue would, for some decades, have been used within Kos to pay for the rebuilding after the severe earthquake of 198.

\section{EARLIER DATINGS}

The first to present an outline of the Koan output of coins was the epigraphist W.R. Paton in the volume The Inscriptions of Cos from 1891. He dated the bearded Herakles drachms and young Herakles hemidrachms, HI XII and XIII, to the 3 rd century, the young Herakles/incuse drachms to between 200-88, and the Apollo hemidrachms to the period 88-50. ${ }^{81}$ In 1897 Head published BMC Caria and, except for the Apollo hemidrachms, his dates were later than Paton's. He dated part of the issue of bearded Herakles drachms (regarded by him as a separate issue) to 190-166?, the young Herakles/ incuse drachms to $166-88,{ }^{82}$ and the Apollo hemidrachms to $88-50 .^{83} \mathrm{He}$ also connected the Koan incuse silver with the Rhodian silver of the same type and stated that it was the Rhodians who introduced the shallow plinthophoric silver in this area. ${ }^{84}$ I will come back to this below.

Head gave a picture of a continuous production of Koan silver all through the late Hellenistic period. ${ }^{85} \mathrm{He}$ was mainly correct in the sequence of the different issues, but his absolute dates were erroneous. Ingvaldsen has shown that the issue of bearded Herakles drachms and the concurrent young Herakles hemidrachms belong in the 3rd century and ended c. 200. ${ }^{86}$

When Robinson in the 1930s and Kroll in the 1960s discussed and revised the earlier datings, the dates proposed by Head were their point of departure. Both started with the

\footnotetext{
80 In contrast to the HI XII and XIII issues, no examples where most or all the obverse motif has been worn away are known. The visible wear on some seems, from the photos, to be due to not only rubbing, but also to wear on dies, to corrosion and to cleaning. To settle this question properly a study of the physical coins would be necessary.

81 Paton \& Hicks 1891, 308 (issues h and j), 313 (issue v), 318 (issue ah).

82 He also put the Asklepios/incuse silver in this period and thus saw these two issues as roughly contemporary.

${ }^{83}$ BMC 19, xciv-xcvii, 200-201, 205, Cos nos. 117, 118; 210, nos. $165-168$.

84 When discussing the Koan drachms he wrote: "They are characterized by the restoration of the incuse square in a shallow form, on the reverses, an archaistic fashion, introduced in the first instance at the Rhodian mint and imitated on the mainland by the Lycians, \&c." (BMC 19, xcvi).

85 In his presentation he does not give any specific arguments for his datings.

86 Ingvaldsen 2002, 117-126, 164.
} 
notion that the issues HI XII and XIII were minted between 190 and 166. As HI XII and XIII were clearly earlier than the young Herakles/incuse and Apollo/lyre issues, the latter necessarily postdated 166

Robinson published the IGCH 1320 hoard in 1936. He saw that the young Herakles/incuse and Apollo issues were contemporary and placed them in the late 2 nd century. Robinson refers to Head for the date 166-88 for the young Herakles/incuse drachms. As for the absolute dating of the Apollo hemidrachms, he compares the head on this issue with that "on the dated series of tridrachms, \&c., from Alabanda", ${ }^{87}$ saying that "special details" are "exactly paralleled" on the two. He does not specify which details. ${ }^{88}$ The Alabanda coins were later dated to the period $166-133 .{ }^{89}$ One obvious similarity is that the Apollo head in several dies is depicted with a similar coiffure, with, for instance, corkscrew locks. They thus show a close similarity in iconographic detail. There are, however, methodological objections to this assumption of contemporaneity. On coins the same iconographic type of a particular deity can be seen over extended periods, both within the same polis and in different city-states. Iconographic similarities thus do not necessarily mean closeness in time, and a direct chronological connection with the Alabandean coins can be questioned. This means that Robinson's argument for a dating "nearly half a century earlier than Head's date", 90 i.e. somewhere in the period $c .135-100$ was far from firm.

In 1964, Kroll analysed the so-called "tetrobols" (Asklepios/incuse silver) in an article where he also suggested an earlier date for the two issues discussed here. Basing his conclusions on the wear and chronological composition of the coins in the IGCH 1320 hoard, as well as on historical arguments and Mario Segre's 1952 publication of Kalymnian inscriptions, he dated the two issues to the middle of the 2 nd century. ${ }^{91}$ Following Head, he wrote that the young Herakles/incuse drachms "were probably first struck after 166 BC in imitation of the restored incuse drachms of Rhodes." ${ }^{92} \mathrm{He}$ thought that $I G C H 1320$ "confirms Head's association of the Koan and Rhodian incuse drachms" as it contained Herakles/ incuse drachms and "hemidrachms of Rhodes in fine to FDC [fleur de coin] state of preservation".93 Recent research has

7 BMC 19, 2, nos. 10-12

8 Robinson 1936, 194

89 Waggoner 1989, 289, series 5.

90 Robinson 1936, 194.

91 Kroll 1964, 83-84.

92 Kroll 1964, 83.

93 The two Rhodian hemidrachms in the hoard belong to Jenkins 1989, Group B. "Fine" must be used in a non-technical sense and mean "in good condition". shown that the earliest Rhodian plinthophoric issues started about 30 years before 166 (see below). ${ }^{94}$

In the later 1990s the post-166 dating was questioned by Ashton. In a note on the pseudo-Rhodian drachms of Kos he wrote that the Herakles/incuse drachms which display a shallow square incuse, a plinthos, "may [...] have begun as early as the 180s". One important reason for this was the fact that, on the basis of epigraphical sources, the earliest Rhodian plinthophoroi, could be backdated to $c .190 .^{95}$

Ingvaldsen discussed the chronology in detail; basically he followed Ashton, and concluded that the Koan issues were minted c. 180-175. He writes, "The most important feature as to the chronology of the issue is the presence of the plinthos [... ] Due to the dominant position of Rhodes in the area at the time, one has suggested, and generally accepted that this particular type of plinthophoroi was introduced on Rhodes and followed by other nearby and/or related states." ${ }^{\text {" }}$ Ingvaldsen agreed with Ashton in placing the introduction of the Rhodian plinthophoric silver $c$. 190, but he dated the Koan silver to the 170s. He pointed out stylistic parallels to Jenkins's group B and wrote, "Due to the stylistic divergences with the earliest issue of Rhodian plinthophoroi, and the natural delay in transferring a newly introduced coin type to other states, a period of minting between the years $c .180-175$ now appears the most probable ..."'

The dating of the two Koan issues has depended on two main arguments. Firstly, Robinson's and Kroll's datings were based on Head's erroneous view that the Koan bearded Herakles drachms (HI XII) should be dated to 190-166. The second argument for a dating after 166 has been the connection made with the Rhodian plinthophoric silver (earlier presumed to postdate 166) which, since Head, has been seen as serving as a model for the Koan issues of the same type. When the introduction of the Rhodian plinthophoroi, in stages, was backdated, so was that of the Koan issues. ${ }^{98}$

\footnotetext{
94 Ashton 2001, 89. Ashton sees Jenkins 1989, group A as beginning $c$. 190 in this article, but now notes that Meadows (2009) by implication pushes the dating of the earliest group back to the mid-late 190s (Ashton 2012, 194).

95 Ashton 1998, 227.

96 Ingvaldsen 2002, 156.

97 Ingvaldsen 2002, 156-157. Ingvaldsen saw stylistic parallels in the lettering of the Koan plinthophoric drachms and Jenkins's group B, i.e. the short transverse bars at the end of the letter strokes. In his discussion he therefore places the Koan incuse drachms after Jenkins's group B (Ingvaldsen 2002, 157). This trait is, however, also found on the Koan issue Höghammar 2007 C, probably dating 201-200. Another matter is that it is hard to know how long a "natural delay" would be, but imitations could have been made very quickly. In my view, ideas did not take over a decade to travel between neighbouring islands.

98 Should the Koan coins imitate the Rhodian, Meadows's recent work implicitly dates the introduction of the Rhodian plinthophoric silver to
} 
The shallow plinthos on the reverse has thus played an important part in the discussions of the date of the two issues. Requier and Ingvaldsen now agree that the Koan mint had coined silver in a technique which later developed into the plinthophoric already with the issue XIV dated c. $280-250 .{ }^{99}$ This changes our view on where the earliest plinthophoroi in the area may have been produced and we can no longer safely assume that the Koan plinthophoric drachms imitated the Rhodian.

\section{REDATING THE ISSUES}

When dating the two issues I will base my conclusion on six different factors:

- The technical characteristics of the issues.

- The transitional character of the coins.

- A discussion of IGCH 1320 containing coins from these and other issues.

- A comparison of the names with those in other issues and in two inscriptions..$^{100}$

- A comparison of the lettering on other issues.

- A stylistic comparison of the Herakles head with the same motif on other issues.

at least as early as $c .195$, making the 190 s a possible date for the Koan issue (Meadows 2009, 61-62, 82).

99 Ingvaldsen writes: "Dies with a moulded square incuse were used for the following issues: XI,1 (didrachms), XIV,1 (tetradrachms), XXIII (drachms [=the Herakles/incuse issue]) and XXVI (bronze coins)." and "The drachms of issue XXIII are often labelled 'plinthophoric' drachms after the plinthos (incuse) on the reverse. ${ }^{185} \mathrm{~A}$ considerable number of plinthophoric drachmas were issued by different mints in Asia Minor during the first half of the second century. This type was named in contemporary sources after the square incuse (e.g. in the Delian inventories), but the die-type and fabric were already in use on the much earlier issues of XI and XIV." Ingvaldsen 2002, 42, 43. In a personal communication Requier, having restudied the issues in December 2012, states that no incuse in issue XI has been imprinted with a plinthophoric die, and in January 2013 Ingvaldsen wrote to me that he now agrees with Requier in this. Requier is of the opinion that the incuse on some of the tetradrachms HI XIV (= Requier 1996) has been produced in a technique which uses a round die with a square shallow plinthos in the centre and a flat surface around it. This flat surface does not, however, cover the entire flan as the outer edges of the latter show a relief. Neither is the flat surface perfectly plane. This can be seen on the actual coins, but not on photographs (an example is Requier 1996, Pl. 5d). I am most grateful to P. Requier for allowing me to use the results of his close work on the dies used on Kos in the third century as it, in my opinion, shows that the plinthorphoric die is more likely to have been developed there rather than at Rhodes.

100 A problem that cannot be addressed in this article is that later Koan bronze issues have not yet been studied in detail, and thus we lack an overview of the names appearing in them.

\section{The technical characteristics}

One important trait of both drachms and hemidrachms is their estimated weight standard. Ingvaldsen has shown that, in the Koan mint, the weight standard of the 3rd century drachms is reduced as compared to the late 4th century issues of the same denomination and the same goes for the didrachms. First I will present the drachms. There was a chronological gap between the latest 4th century issue (HI VIII) and the 3rd century issue (HI XII) of c. 30-60 years. The weights of the 55 weighed coins from HI VIII dating to the second half of the 4th century range between $2.93-3.72 \mathrm{~g}$ with a peak at $3.35 \mathrm{~g}$, whereas the weights of the 172 weighed coins of his issue XII dating c. 260-200 range between $2.31-3.35 \mathrm{~g}$ with a peak at $3.00 \mathrm{~g} .{ }^{101}$ Now I will pass to the didrachms. In 2010 I investigated the weights of the later 4th and the 3rd century issues of Koan didrachms. There is a clear difference between the maximum weights in the different issues, with $44 \%$ of the 133 weighed coins weighing above $6.80 \mathrm{~g}$ in the $340 \mathrm{~s}$ (HIIV), and fewer than $3 \%$ of the 81 weighed coins weighing above $6.80 \mathrm{~g}$ in HI XI dating $c .280-250$. None of the 18 examples in the slightly later issue, HI XV, c. 250-240 weighed above $6.80 \mathrm{~g}$. The same tendency seems to exist also in the Rhodian issues of didrachms. ${ }^{102}$ There is thus, in the Koan mint, an obvious tendency towards lighter coins with the passage of time. We cannot prove that this tendency was continued in the 2nd century, but the vast expenses caused by the wars and the earthquake in the early part of it, make it unlikely that it was discontinued. The fact that both the issues discussed in this article have the same estimated weight standard, 3.20-3.30 $\mathrm{g}$ and $1.60 \mathrm{~g}$, as the $3 \mathrm{rd}$ century issues is thus an indication that they were produced soon after the latter. ${ }^{103}$ The somewhat later Asklepios/incuse issue was, in my opinion, minted on a different standard, the coins in it weigh about two thirds the weight of the earlier Rhodian drachms. The Hellenistic Koan issues

\footnotetext{
101 Ingvaldsen 2002, 44-46, 107-108, 118. There are also two earlier issues of drachms from the early and middle part of the 4th century, HI issues II and V, but we have so few coins from them (three and eight respectively) that no certain conclusions can be drawn from that material. Ingvaldsen 2002, 90, 97, 229.

102 Höghammar 2010a, 512-514, 522 (Table 2).

103 The island of Kos was hit by a major earthquake in 198 and the reconstruction work must have been drawn out and costly. Ashton has dated the beginning of the Rhodian drachms of reduced weight, 2.80 $\mathrm{g}$, (still part of the same issue as the earlier and heavier drachms) to the 220 s, and he suggested that the connected tetradrachms were struck to pay for the repair work done after the earthquake which hit Rhodes in 227-226 (Ashton 2001, 93). As the weight reduction of the Rhodian drachms comes after the disaster it is likely that this measure is a sign that the Rhodian state was forced to lower the weight (but keep the official value) in order to be able meet the expenses caused by the reconstruction work. We have a parallel situation at Kos in the early 2 nd century which probably also led to coins being struck at a lower weight, but here there is a change of weight standard from the Rhodian to the "Persic"/Microasiatic.
} 
were minted on the Rhodian weight standard and the issues of the two islands parallel each other in the weight reduction evident in the material. The fact that the Koan plinthophoroi had the same weight standard as the earlier issue of Koan drachms, heavier than that of the lower-weight Rhodian plinthophoric drachms, indicates that they preceded the latter. ${ }^{104}$

The fact that the upright die-axis is the same as in the preceding issues is not significant as this was also the case in the 2nd century. More interesting is the fact that the flan diameter (and thickness) seems to be just about the same as in the 3rd century issues. One can see a general tendency towards larger, thinner flans, but this had already started in the 3rd century issues. Well over half the coins in both pairs of issues have the same diameter and there are only a small number of coins in the later issues which have a slightly larger diameter. This shows that there is no leap to markedly larger flans in the later issues, but rather a continuation of an already existing trend.

\section{The IGCH I 320 hoard found on Kalymnos}

This hoard is important as it is the only Koan hoard from the period which includes more than two different issues. ${ }^{105}$ It contains Koan 3rd century drachms, Herakles/incuse drachms, Apollo/lyre hemidrachms and several Koan bronze issues along with Kalymnian and Rhodian silver. It has hitherto been regarded as a savings hoard, but I will argue that it is a currency hoard, buried as early as $c .190$.

Two of the four Rhodian coins reported are regarded as probable intrusions, ${ }^{106}$ and so the integrity of the hoard can perhaps be questioned. ${ }^{107}$ The other 45 coins described by Rob-

104 Their being heavier than the Rhodian plinthophoric drachms was first brought to my attention by R. Ashton.

105 The Rhodian hoard IGCH 1321, which also includes three Koan coins belonging to the issues presented here, will be discussed below.

106 Ashton 1996, 279, 1998, 227, n.14. Ashton noted that these two coins stand out from the rest being both later in date and displaying a higher degree of wear.

107 The combination of silver and bronze coins in the same hoard is unusual. To see just how rare such mixed hoards are and how they are composed, I have gone through the hoard inventories in the $I G C H$ and the first ten Coin hoards volumes. The occurrence of silver and bronze coins in the same hoard occurs regularly in different regions and periods. In the region of the Aegean and surrounding area almost 50 such hoards are reported. In the 47 hoards listed below those given as uncertain and entries referring to coins found in general excavations and graves have been excluded. Greece and the southern Balkans: $I G C H$, nos. 122, 124, 143, 159, 162, 200, 301, 302, 330, 386, 522; $C H$ I, no. 42; $C H$ III, nos. 23, 54, 84; $C H$ V, no. 30; $C H$ VIII, nos. 77, 392, 409, 521; $C H$ IX, nos. 58, 161, 162, 201, 243; CHX, nos. 64, 74, 75, 103, 107, 124, 171, 191. Asia Minor and Cyprus: IGCH nos. 1211, 1217, 1227, 1288, 1297, 1330, 1346, 1352, 1475; $C H$ II, no. 84 (= IGCH 1342), $C H$ VIII, no. 239; $C H$ IX, no. 375, 503; $C H$ 10, no. 270. Most consist mainly of either silver or bronze with just an occasional coin of the other metal, but a third have more than just a couple of coins in both metals. With four exceptions ( $\mathrm{CH}$ III, nos. 54 and 84, $\mathrm{CH} \mathrm{10,} \mathrm{nos.} 103$ and 191) the 18 inson are, however, chronologically homogeneous and therefore I regard them as belonging to one and the same hoard.

The hoard, when first published by Robinson in 1936, was dated shortly before $100 \mathrm{BC} .{ }^{108}$ In 1964 Kroll placed the burial of the hoard at $c .150 .{ }^{109}$ Mørkholm gave the hoard a deposit date of 200-175 in $I G C H .{ }^{110}$ In 1996 Ashton gave the hoard a concealment date in the second, or, more likely, the third quarter of the 2nd century, but in 1998 he tentatively suggested a deposit date shortly before the late 170 s. ${ }^{11}$ Ingvaldsen, following Ashton, gave the hoard a concealment date in $c .175$, and Giannikouri \& Stefanaki in 2011 suggested the end of the $180 \mathrm{~s}-c .175 / 70$ or $c .150{ }^{112}$ Until the $1990 \mathrm{~s}$ the other silver issues were regarded as earlier than the two issues under discussion here, and, excluding the two (pseudo-) Rhodian drachms, this is still the case. The main reason for this (apart from their state of wear) is that the Herakles/incuse issue has been regarded as copying the (earliest) Rhodian plinthophoroi. ${ }^{113}$ However arrived at, it has been the date given to the Herakles/incuse and Apollo/lyre issues which has also determined the suggested deposit date of the hoard.

Much work has recently been done on Koan silver and bronze issues between the middle of the 3rd century and the early 2 nd century by Ingvaldsen and by Giannikouri \& Stefanaki. ${ }^{114}$ The Kalymnian Hellenistic silver has also been analysed. ${ }^{115}$ We are thus in a much better position to date the

hoards listed below consist of coins from at least two different mints. The coin hoard from Kalymnos is thus typical of one type of mixed hoard (AR and $\mathrm{AE}$ ) deposited in and around the Aegean region, mainly in the later 4th to 2nd centuries. Entry number (in bold) from the volume is followed by date and number of coins. Small Roman numerals denote centuries. Eighteen hoards with five or more coins of silver and bronze respectively are listed. $I G C H$, nos. 162 , c. $250 \mathrm{BC}$ (30 AR, $9 \mathrm{AE}), 200$, iii (46 AR, $154 \mathrm{AE}$ ), 301 ii (167 AR, $13 \mathrm{AE}$ ), 302, ii (5 AR, $93 \mathrm{AE}), 330$, early i (54+ AR, 44+ AE), 386, c. 340-30 BC (18 AR, $11 \mathrm{AE}), 522, c$. $125 \mathrm{BC}$ ? (25 AR, $50 \mathrm{AE}), 1217$, c. 334-32 BC (50 AR, $175 \mathrm{AE}$ ), 1227, iv? (19 AR, $74 \mathrm{BIL}, 10 \mathrm{AE}), 1297$, c. $240 \mathrm{BC}$ (c. $300 \mathrm{AR}$ and AE, 6+ AR, 133+ AE), 1352, ii-i (8 AR, c. $20 \mathrm{AE}) ; \mathrm{CH}$ III, nos. 23, 315 BC (6 AR, $380 \mathrm{AE}), 54,160 \mathrm{BC}$ (5 AR, $44 \mathrm{AE}), 84,20 \mathrm{BC}$ (29 AR, $58 \mathrm{AE})$; $\mathrm{CH}$ IX, 243, 168 BC (16 AR, $42 \mathrm{AE}$ ); CHX, nos. 64289-79 (5 AR, $34 \mathrm{AE}$ ), 103, late iii/early ii (5 AR, $44 \mathrm{AE}), 171$, mid i? (19 AR, $2749 \mathrm{AE}), 191$, late i-early i $\mathrm{AD}$ (28 AR, $58 \mathrm{AE})$.

108 Robinson 1936, 190-194.

109 This deposit date was thus based in part on Head's mistaken dating of the Rhodian plinthophoric issues. Kroll also included the dating of the Kalymnian coins in his reasoning. Kroll 1964, 83-84.

110 IGCH 1320.

111 Ashton 1996, 279, 1998, 227, n.14.

112 Ingvaldsen 2002, 157-158; Giannikouri \& Stefanaki 2011, 350351. Their later date of $c .150$ follows Apostolou 2002, 143-144, but, considering the discussion in Ashton 2001, 89 and Meadows's recent redating of the deposit date of the Mektepini hoard, I find this late dating of the Rhodian hemidrachms highly unlikely.

113 This is, as just discussed, probably mistaken.

114 Ingvaldsen 2002 and Giannikouri \& Stefanaki 2010.

115 Höghammar 2010a, 497-528. 
other coins in the hoard than was the case earlier. I have therefore, in the following discussion, left the dating of the Herakles and Apollo silver and the bronze issue HI XXVI ${ }^{116}$ open, and given the other issues present the dates now accepted by scholars working on the Koan mint ${ }^{117}$ to see if they may help us date the issues under examination.

\section{Size and composition}

According to Robinson the hoard consisted of 92 silver and 54 bronze coins. A few of the silver coins were almost in mint condition and another 50 pieces were "so heavily oxidized as to be worthless". ${ }^{118}$ Only 47 coins were properly described, comprising Koan bearded Herakles drachms (HI XII), Herakles/incuse drachms (HI XXIII), Apollo hemidrachms (HI XXIV), coins of four different bronze issues (HI XVIII, XVII, XIX and XXI) ${ }^{119}$, Kalymnian silver and Rhodian silver.

In the list of Koan silver coins below, the magistrates' names are given in the order proposed by Ingvaldsen.

\section{Koan silver}

Bearded Herakles/crab, club, HI XII. Date c. 280/60-200, ${ }^{120}$ 23 known names in issue.

Pythion ( $4^{\text {th }}$ in Ingvaldsen's catalogue, one coin)

Nikagoras (1 $3^{\text {th }}$, two coins)

Astynomos $\left(15^{\text {th }}\right.$, two coins $)$

Filinos (16 $6^{\text {th }}$, four coins)

Kallippidas (17 $7^{\text {th }}$, three coins)

Zopyrion (19 $9^{\text {th }}$, one coin)

Herakleitos (21 ${ }^{\text {st }}$, one coin)

Young Herakles/crab, club in incuse, HI XXIII, 8 known names in issue.

$\operatorname{Archias}\left(1^{\text {st }}\right.$, one coin)

$\operatorname{Aratos}\left(2^{\text {nd }}\right.$, one coin $)$

Aristaios ( $3^{\text {rd }}$, one coin)

Patrokles ( $4^{\text {th }}$, two coins $)$

Aristandros ( $8^{\text {th }}$, two coins)

Apollo/lyre hemidrachms, HI XXIV, 16 known names in issue. Archias (6 $6^{\text {th }}$, one coin)

Patrokles $\left(7^{\text {th }}\right.$, three coins $)$

Aristaios ( $9^{\text {th }}$, five coins)

Thrasyandros $\left(10^{\text {th }}\right.$, one coin $)$

\footnotetext{
116 The dating of this issue depends on the dating of the Herakles and Apollo silver (Ingvaldsen 2002, 163).

117 In no case is their dating connected to their appearance in this hoard.

118 Robinson 1936, 193.

119 The issues are listed in the chronological order suggested by Giannikouri \& Stefanaki 2010.

${ }^{120}$ Ingvaldsen 2002, 164; Höghammar 2013, 219-220.
}

\section{Koan bronze}

Seven coins are described by Robinson; another 47 not seen by him are said to be of the same types, and mostly with a crab in countermark.

Head of young Herakles/crab or crab and club, HI issue XVIII. Date, Giannikouri \& Stefanaki c. 260/50-240/30, Ingvaldsen $c .250-200 .^{121}$

No name given (two coins)

Draped female head/crab, occasionally club, HI issue XVII. Date; Giannikouri \& Stefanaki c. 220-200, Ingvaldsen $c$. 250-200. 20 known names in issue. ${ }^{122}$

Praxianax $\left(7^{\text {th }}\right.$, one coin $)$

Head of young Herakles 3/4 facing/club, bow-in-case, HI XIX. Date; Giannikouri \& Stefanaki c. 210-190/85, Ingvaldsen $c$. $210-180,{ }^{123} 21$ known names in issue.

Archon, crab in countermark ( $4^{\text {th }}$, type 1 , one coin)

Pratagoras ( $6^{\text {th }}$, type 1 , one coin)

Lampias, crab in countermark ( $9^{\text {th }}$, type 1 , one coin)

Head of young Herakles/crab in incuse, HI XXVI. Date, Giannikouri \& Stefanaki 180-170, Ingvaldsen, as issues XXIII and XXIV. Two known names in issue. ${ }^{124}$

Damonos (one coin)

Kalymnian silver ${ }^{125}$

Helmeted head/lyre. Rhodian weight didrachms. Date, Höghammar c. 260/50-200. ${ }^{126}$

No magistrates' names (four coins)

Helmeted head/lyre. "Persic"/microasiatic weight drachms. Date, c. 201-200. ${ }^{127}$

Kleuphanes and Peisistratos (two, possibly three coins)

121 Stefanaki 2012, 253, issue 23; Ingvaldsen 2002, 164. Giannikouri \& Stefanaki $(2010,454)$ date the issue $c$. 275/50-250/25, but in $K \Omega \Sigma$ I (2012) Stefanaki has narrowed down the period to the one given above. 122 Giannikouri \& Stefanaki 2010, 455; Ingvaldsen 2002, 139, 164.

123 Giannikouri \& Stefanaki 2010, 451; Ingvaldsen 2002, 164.

124 Giannikouri \& Stefanaki 2010, 460; Ingvaldsen 2002, 162-164. The date given by the former is based on Ingvaldsen (information from Stefanaki in an e-mail). Ingvaldsen's date is the same as for the Herakles/ incuse and Apollo/lyre silver as he connects this bronze issue to the silver issues.

125 Robinson 1936, 190, no. 38, and 193. See Höghammar 2007, 90-92 for a discussion of these coins and Höghammar 2010a for a general discussion of the Kalymnian Hellenistic silver coinage.

126 Höghammar 2010a, 517.

127 Höghammar 2010a, 517. 
Helmeted head/lyre. "Persic"/microasiatic weight hemidrachm. Date, c. 201-200. ${ }^{128}$

Kleuphanes (one coin)

\section{Rhodian silver}

Hemidrachms, Jenkins 1989, group B. Date c. 190-180/175 ?'29

Dexagoras (cf. Jenkins's no. 39, one coin)

Xenophantos + star (cf. Jenkins's no. 41, one coin).

Pseudo-Rhodian drachm. Date Ashton, c. 170 (probably intrusive). ${ }^{130}$

Eubios (one coin)

Rhodian or (more probably) pseudo-Rhodian drachm, magistrate's name obliterated, countermark chimaera (probably intrusive). ${ }^{131}$ Date of countermark, c. 170 (one coin) ${ }^{132}$

The two (pseudo-)Rhodian-type drachms in the hoard are considerably later, $c$. 170, than the other issues in it. Ashton, followed by Ingvaldsen, suggested that they may be intrusions. ${ }^{133}$ Should the hoard be a savings deposit, the presence of these coins could be explained, but if that were the case, the chronologically homogeneous character of the Koan and Kalymnian silver and the Koan bronze issues present in it would need to be explained as would the similarity of the composition of the Koan silver with that of other Koan hoards dating to $c .200$ (see below). ${ }^{134}$ On balance I regard the drachms as intrusions.

Apart from the Herakles/incuse and Apollo/lyre silver and the associated bronze issue, all the Koan and Kalymnian coins, both silver and bronze, date from the middle of the 3rd century down to the 190s. Only a few of the coins are from the early part of this period, the majority belongs to the decades around 200, as if the contents of the hoard were taken out of circulation on one particular occasion. A closer look shows that the chronological composition of the group of bearded Herakles drachms is similar to that in other hoards containing such drachms and the parallel issue of hemidrachms (HI XII

128 Höghammar 2010a, 517.

129 The deposit date of the Mektepini hoard, implicitly dating the earliest Rhodian plinthophoric silver (group A), was put back to $c .195$ by Meadows 2009, 61-62, 82.

130 Ashton 1996, 279, 1998, 227, n. 14

131 Ashton 1996, 279. 1998, 227, n. 14

132 The descriptions of the last two coins are from Ashton 1996, 279.

133 When discussing the deposit date of $I G C H 1320$ Ashton wrote, "If this [the suggested deposit date] is right, the pseudo-Rhodian drachm and the counter-marked (pseudo-) Rhodian drachm were indeed probably intrusive." Ashton 1998, 227 and n. 14; Ingvaldsen 2002, 156-157. 134 A currency hoard deposited in an emergency would contain coins in circulation at the time of burial, whereas a savings hoard would contain coins from different periods. A savings hoard would normally contain mainly silver. and XIII) with a deposit date at the very end of the 3rd century. ${ }^{135}$ We have $I G C H 1308$ with 28 early and 170 late coins, ${ }^{136}$ IGCH 1309 with 27 late coins, Ingvaldsen 2002, no. 22 with three early names and 14 late names (the number of coins for the individual moneyers is not given), and finally Höghammar 2006 with six early and eleven late coins. In three of the four hoards both early and late coins from the issues are represented, but the late coins dominate strongly. The fourth hoard, $I G C H 1309$, contains only late drachms. In IGCH 1320 we have one early and 13 late drachms, i.e. the same chronological spread is displayed.

The seven Kalymnian coins in IGCH 1320 must predate 200. Kalymnos was then reincorporated into the polis of Kos, became a Koan deme and could no longer issue its own silver. In my 2010a article I argue for a date $c$. 260-200 for all the Kalymnian Hellenistic silver issues. The silver with names should date to very last years of the 3rd century. ${ }^{137}$

Excluding the Rhodian silver we thus have a group of silver coins, Koan and Kalymnian, of which a few are from the middle of the 3rd century, but by far the largest part dates to its very end. The chronological composition and the proportions of early and late coins from the bearded Herakles issue in IGCH 1320 is similar to that of the Koan drachms in four of the other hoards deposited $c$. 200, indicating that is was deposited at about the same time.

The bronze coins present a similar picture. ${ }^{138}$ Three belong to issues dating c. 250-200, and three to HI XIX dated $c$. 210-190/80. The HI XIX coins belong to Ingvaldsen's type 1 (with the ethnic $\mathrm{K} \Omega I O N$; his second type in the same issue has the later ethnic $\mathrm{K} \Omega \mathrm{I} \Omega \mathrm{N}$ ), dating from $c .210$ into the 190s. This issue (BMC 103-110) has an absolute terminus ante quem as it is represented in two different archaeological contexts on the agora of Athens, ${ }^{139}$ which by their contexts are dated to $c$. 230-190/80. One coin, no. 958a, is from a find

\footnotetext{
135 A detailed presentation of these hoards is given in Höghammar 2013, 211-214.

136 The name Chairylos appears in both 3rd century issues (as the eleventh name of 23 in the relative order of moneyers on the drachms and as the ninth of 21 names on the hemidrachms). There is a change in character of output and outlook (only drachms) of the coins minted after him. I have labelled the group of coins issued before or by Chairylos as early, and the group of coins issued after him as late. The late groups will be used in comparisons with the presently discussed issues.

137 Höghammar 2010a, 495-526.

138 It was only with Ingvaldsen 2002 that the Koan bronze issues were more thoroughly analysed and given closer datings. These were then somewhat revised by Giannikouri and Stefanaki in 2010. This is the first time that all the bronze issues in the hoard are discussed in connection with its dating.

139 Kroll 1993, 274. When visiting the Agora museum I noted that both coins are severely corroded.
} 
context closed in $183 / 2 .{ }^{140}$ The other coin, $958 \mathrm{~b}$, appeared in a different context together with coins dating from the 220 s to not later than $187 . .^{141}$ The two find contexts suggest that the coins of this issue should not be later than the early 180 s, and they are more likely to belong to the late 3rd century or the 190 s.

Two of the HI XIX coins in the hoard have on the reverse a square countermark with a crab, and Robinson was told that most of the bronze coins not seen by him carried the same countermark. One may think that this is a sign of their circulating over a long period of time and be an argument for a late deposit date of this hoard. Before discussing these countermarked coins, a few general considerations on countermarks, and some general information on the issue HI XIX are necessary. Countermarks can be applied for a variety of reasons. When used on bronze by the same authority which produced the original issue, two possibilities appear most likely. One is to continue in use a coin which has seen extreme wear, i.e. has been in circulation for a considerable period of time. A second is to revalue the coin, up or down, often in connection with a crisis of some kind. ${ }^{42}$

Howgego, in his work on Greek Imperial countermarks, ${ }^{143}$ notes that a coin may not be worn when countermarked, but

\footnotetext{
140 This coin was found in the construction fill of the Middle Stoa on the agora which contained 189 identifiable coins giving a nearly complete run of Athenian bronze from c. 350 "down to the closing of the fill in 183 BC" (Kroll, 49-50). The closing date is based on Grace's (1985) chronology of Rhodian amphora handles. On the lower chronology subsequently proposed by Finkielsztejn (2001), the closing date of the fill would be 169/67 (or 170/68). The lower chronology is, however, still debated: Magnetto $(2008,75-77)$ has presented serious objections to a date in the later 180s for the Rhodian eponymous priest Pratophanes, supported by among others Finkielsztejn and Habicht; she offers convincing arguments for placing him in the 190s which supports Grace's early chronology; she gives a good overview of the sources pertaining to the document in which Pratophanes is mentioned, a Rhodian arbitration between Samos and Priene.

141 958b was found together "with other coins, the latest being Athenian Period II pieces of c. 220's-190's BC and 991, Antiochos III, 223187 BC" (Kroll 1993, 274). The coin, 958b $(=\Theta-291)$ was, as far as I can see, not found in a closed context, but, as all the other coins found with it are no later than $c .220 s-190 \mathrm{~s} / 187$, it is reasonable to conclude that this coin is no later.

142 See, for instance, Milne 1939, 75-76. Mørkholm $(1991,126)$ suggests that the countermarks on the bronze coins at Sardis issued by Achaios in the 210s "may have been intended to increase their nominal value during the siege of the city by Antiochos III". Much later, in the 3 rd century AD, the face values of civic coins could be doubled through countermarking (Howgego 1995, 122).

143 As the countermarking of Greek Imperial coins developed out of the Hellenistic practice (Howgego 1985, 1), the conclusions reached by Howgego are most likely valid also for Hellenistic bronze issues. More recently O.D. Hoover has catalogued and discussed the Hellenistic countermarks on Seleucid and foreign bronze coins (Hoover 2008, 157-208). The difference between the comparatively minute independent Koan polis with bronze issues minted for local/internal circulation and with no
}

having a countermark allowed it to circulate until it was well worn. The type of a countermark is recessed into the coin and does not wear as the original type does; this means that coins could be countermarked very shortly after being struck, sometimes the same year. In his opinion, "To prove that a countermark was applied specifically to revalidate worn coins one must show that all (or a high proportion) of the coins countermarked were very worn." 144

Ingvaldsen lists 287 coins in issue XIX.145 Almost 25\%, 71 coins, have a countermark, in all but four cases (twice a club, twice a gorytos) a crab. The legends are still readable on 26 of these coins and on 45 the legends are partly (name not readable) or completely obliterated. ${ }^{146}$ Almost two thirds of the countermarks are thus on coins showing heavy wear. Looking at the entire issue one can see that 115 coins have completely obliterated legends and that 38 of these, $33 \%$, are countermarked. As mentioned, Ingvaldsen divides the issue into two types, the first which is earlier and the second which is later; ${ }^{147}$ type 1 with 97 coins of which 33 are countermarked and type 2 with 75 coins, none with countermarks. ${ }^{148}$ We cannot be certain that the countermarks on the worn coins were applied when they had reached an extreme state of wear. They could have been applied earlier. Generally one may assume that often only a short time passed between striking and countermarking. In this issue a fairly low proportion, $65 \%$, of the countermarks is on extremely worn coins; consequently we cannot with any confidence conclude the countermarks to have been applied in order to revalidate worn coins. This conclusion is strengthened by the fact that none of the later, type 2 coins, were countermarked. ${ }^{149} \mathrm{Had}$ the countermarks, several decades after the minting of the issue, been applied on severely worn coins, surely some of the type 2 coins would also have been countermarked. Based on the evidence presently at hand, the obvious conclusion I come to is that the coins were countermarked when issue XIX was still being minted, before type 2 was introduced and for reasons which remain obscure.

The more precise datings of Ingvaldsen and Giannikouri \& Stefanaki show that the Koan bronze coins in the hoard belong to the middle to second half of the 3 rd century or the very beginning (first decade) of the 2 nd. Their dates are thus

\footnotetext{
foreign issues allowed, and the vast Seleucid empire including many citystates which allowed the circulation of royal and foreign issues within their own territory is large. Direct comparisons as to the function of the countermarks are therefore hazardous.

144 Howgego 1985, 8, 11.

145 Ingvaldsen 2002, 324-343.

146 All but three of the extremely worn coins are in Göttingen, i.e. originally from the Asklepieion.

147 Ingvaldsen 2002, 143.

148 The type of the rest of the countermarked coins cannot be determined.

149 New evidence may, of course, change the picture.
} 
the same as or just a few years later than the silver coins in the other hoards with a deposit date at the very end of the 3 rd century. Thus the bronze coins, also, indicate that $I G C H$ 1320 was deposited very shortly after the other Koan hoards. The Kalymnian and Koan part of the hoard is chronologically homogeneous.

Robinson commented that "the bronze was fairly uniform in showing a certain amount of wear". He described the two pseudo-Rhodian drachms as "considerably rubbed". It is very difficult to determine what Robinson meant exactly when using these expressions, but to me it seems clear that he considered the bronze as less worn than the two (pseudo-) Rhodian drachms. To judge from Robinson's description, the issue XIX bronze coins did not exhibit extreme wear and thus they probably had not circulated over a particularly long time (several decades) before being deposited.

I will now discuss the Rhodian silver. The two Rhodian plinthophoric hemidrachms in IGCH 1320 belong to Jenkins's group B. ${ }^{150}$ Meadows has shown that the burial dates of the Mektepini (IGCH 1410) and other hoards, on which the start date of the Rhodian plinthophoroi has hitherto relied, should be moved back from $c .190$ to $c .195,{ }^{151}$ showing that the Rhodian Alexanders with the same names as those on plinthophoroi of Jenkins's group A were in circulation before c. $195 .{ }^{152}$ As pointed out to me by R. Ashton, this means that the succeeding group B may have started as early as $c .190$. This makes the Rhodian hemidrachms the latest externally dated coins in the hoard.

To judge from Robinson's text, the relative wear of the silver coins agrees with the idea of $I G C H 1320$ being a currency hoard. The oldest coins (HI XII) show most wear. The Rhodian-weight didrachms from Kalymnos, "were a trifle rubbed" and should be somewhat later. ${ }^{153}$ The Kalymnian coins with magistrate's names showed "little sign of circulation". The young Herakles/incuse and Apollo/lyre silver were "practically uncirculated", some even "fleur de coin". ${ }^{154}$ The relative wear of the coins, as described by Robinson, suggests that the Kalymnian silver with a magistrate's name and the two Koan issues under discussion are just about contemporary. This

150 Jenkins 1989, 107.

151 Meadows 2009, 61-62, 82. The accepted deposit date of this hoard was, prior to Meadows's article, $c$. 190. In an article from 2010 Hoover accepts Meadows's new dating, while pointing out that a deposit date of c. 190 is still a possibility (Hoover 2010, 131).

152 The Group A plinthophoroi were thus also in circulation before $c$. 195. The Koan plinthophoric issues, even if modelled on a Rhodian series, may thus well have been minted in the 190s.

153 The small difference in the amount of wear suggests that these coins were issued not long before the coins with a magistrate's name.

154 Robinson 1936, 194. places the beginning of the latest Koan silver in the hoard to just after 200.

Robinson described the intrusive (pseudo-)Rhodian drachms as "considerably rubbed" and the Rhodian hemidrachms as "fine". ${ }^{155}$ Kroll wrote that the Rhodian hemidrachms were "in fine to FDC [fleur de coin] state of preservation". ${ }^{156}$ As the latest externally dated coins in the issue are in an almost FDC state of preservation, there is no internal reason for placing the deposit date later than the time of their minting. The names on the hemidrachms are the first and the third in Jenkins's list and, accepting Meadows's deposit date for the Mektepini hoard, $I G C H 1320$ was, most probably, deposited in c. 190.

\section{IGCH I32I (Fig. 8)}

In the ANS (American Numismatic Society) collections there are 27 coins from the hoard IGCH 1321 (=Noe 1937, no. 864) found on Rhodes in the 1930s. Three of these coins belong to the two Koan issues under discussion, and 24 are Rhodian plinthophoric drachms, of Jenkins's group A, B and C (available on http://numismatics.org/search/ nos. $44.100 .48755,57-60,62,63,65-81,92-94)$. These coins, the only known specimens from the hoard, make up just about $7 \%$ of the original c. 400 silver coins. We don't know on what grounds the selection of these particular coins was made, and if and what other series were included in the hoard. All the ANS coins show comparatively little wear, so maybe only the coins in best condition were chosen. Whatever the selection principle was, the low percentage of known coins makes it impossible to say if they are representative of the hoard as a whole. Consequently, an analysis of the group will inform us of its composition and the relative state of wear of the individual specimens in it, but no generalizations to the hoard as a whole can be made.

The Koan coins, one drachm and two hemidrachms, show next to no wear. The Rhodian silver belongs to three different series, Jenkins's group A, B and C (Fig. 8). P. van Alfen, who has looked at the actual coins, considers the following Rhodian coins to exhibit most wear; 1944.100.48757-58, 777. Those with the least wear are 1944.100.48759, 775, 778, 779 . The first three belong to group B and the last four to group C. The Koan coins show less wear than the least-worn Rhodian coins. This result should give us an idea of their time of circulation and the relative age of the coins, the group A and $\mathrm{B}$ coins being the eldest, then the group $\mathrm{C}$ specimens and the Koan coins the youngest. There are, however complicating factors. In the group there are also specimens which

\footnotetext{
155 Robinson 1936, 194.

156 Kroll 1964, 83. Robinson and Kroll must mean "fine" in a non-technical sense, i.e. in good condition.
} 


\author{
APTEM $\Omega N$ \\ 44.100.48759 Artemon(?) + bipennis (cf. Jenkins C 74) \\ 44.100.48760 APXEM $\Omega \mathrm{N}$ (= Artemon?) + bipennis \\ 44.100.48762 + shield (cf. Jenkins C 61) \\ 44.100.48763 + wreath (cf. Jenkins C 75) \\ 44.100.48765 + Isis crown (cf. Jenkins B 33) \\ 44.100.48766 + Isis crown (cf. Jenkins B 33)
}

\section{$\triangle$ EЕIKPATH $\Sigma$}

44.100.48767 + caduceus (cf. Jenkins B 37)

44.100.48768 + caduceus (cf. Jenkins B 37)

44.100.48769 + right hand (cf. Jenkins C 58)

44.100.48770 + right hand (cf. Jenkins C 58)

44.100.48771 + thyrsus (cf. Jenkins C 71)

\section{$\mathrm{MNHM} \Omega \mathrm{N}$}

44.100.48776 + cornucopiae (cf. Jenkins B 34)

44.100.48777 + uncertain (cf. Jenkins B 32)

\section{$\Theta P A \Sigma \Upsilon M E N H \Sigma$}

44.100.48772 + rising sun (cf. Jenkins B 38)

44.100.48773 + rising sun (cf. Jenkins B 38)

44.100.48774 Thrasymenes(?) + cock (cf. Jenkins C 82)

44.100.48775 + tripod (cf. Jenkins C 77)

\section{छENOФANTO $\Sigma$}

44.100.48781 + caduceus/ram's head (cf. Jenkins A 19)

\section{$\mathrm{A} \Theta \mathrm{ANO} \triangle \Omega \mathrm{PO} \Sigma$}

44.100.48757 + wing (cf. Jenkins B 36)

44.100.48758 + wing (cf. Jenkins B 36)

\section{ANA $\Xi I \triangle O T O \Sigma$}

44.100 .48755 + serpent coiled around serpent (cf. Jenkins A 15, B 30, snake-on-omphalos)

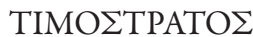

44.100.48778 + dog's head (cf. Jenkins C 81, mule (?) head) 44.100.48779+ cult statue (cf. Jenkins C 79, herm)

\section{$\mathrm{XA} \Lambda \mathrm{INO} \Sigma$}

44.100.48780 + wing (cf. Jenkins C 57)

Fig. 8. List of Rhodian plinthophoric drachms in IGCH 1321.

either show less or more wear than what could be expected: no. 1944.100.48766 (group B) shows comparatively little wear and no. 1944.100.48780 (group C) comparatively much wear. It is, of course, very difficult to estimate the time of circulation as so many factors are involved. The least worn coins saw virtually no circulation and the most worn probably two to three times the amount of circulation of the least worn specimens. An educated guess would be a period of fewer than ten years (possibly fewer than five) for the most worn. ${ }^{157}$

The picture we get from the wear is one where all the coins should be placed within a period of fewer than ten years with the Koan coins at the very end of the period. This does not fit with the accepted dating of Jenkins's group A (earliest) to C (latest) which is spread out over a much longer period, c. 50 years. Should we accept the relative chronology as indicated by the relative state of wear in this group of coins and combine it with the accepted datings of the Rhodian 2 nd century plinthophoroi, we would have to place the Koan issues in the second half of the 2nd century, a date which is clearly implausible. These dates force us to presume that at least some of the coins in the described group had been taken out of circulation for several decades. ${ }^{158}$ This means that the Koan coins may also have been out of circulation for a considerable period of time before being placed in the hoard. A not unlikely possibility is that, after being brought to Rhodes they were kept, but not circulated as they were not valid currency there, i.e. if brought to Rhodes just about fresh from the mint they would remain in that condition. Their excellent state of preservation could thus have at least two explanations, either that they were the latest coins minted, or they had been kept out of circulation over a period of time.

The small group of selected coins (only c. $7 \%$ of the hoard), all showing little wear (indicating that their state of preservation was the criterion for selection), the short time of circulation, probably not more than ten years, and the occasional coin from group B showing comparatively little wear and from group $\mathrm{C}$ showing comparatively much wear means that the group as a whole is difficult to interpret in terms of their relative age. Should one use it for a closer dating of the Koan issues in it, the results would be highly questionable.

\section{Bronze coins found in the excavations of the Asklepieion on Kos}

Herzog and Schazmann showed that the sanctuary of Asklepios, situated about $3 \mathrm{~km}$ outside the town of Kos, underwent major reconstruction in the first half of the $2 \mathrm{nd}$ century BC, almost certainly to repair damage caused by the earthquake in $198 .{ }^{159}$ In the period immediately after the

157 This is the estimate of P. van Alfen from a close inspection of the coins. I am most grateful for his help with an estimate of the wear based on the physical coins and also on their time of circulation.

158 Even if we push back the earliest date of the issue $\mathrm{C}$ coins to (just?) before 150, the recent redating of the Mektepini hoard (Meadows 2009) places group B probably in the 180 s, leaving us with a period of 20 to 40 years between the group $\mathrm{B}$ and $\mathrm{C}$ coins. This seems too long for the amount of wear visible on these coins.

159 Herzog \& Schazmann 1932, 72-75. The chronology was based on architectural considerations. See also Höghammar 1993, 25-26 for a 
earthquake the number of visitors to the Asklepieion must have declined considerably and fewer coins would have been dropped there. ${ }^{160}$ At first it must have been dangerous, and access to the area was probably restricted. These events can be connected with the picture created by the finds of single bronze coins from the German excavations in the sanctuary, which are now in Göttingen. Ingvaldsen summarizes and divides into issues those dated down to the early 2 nd century, ${ }^{161}$ a total, including a few silver pieces, of 435 coins. ${ }^{162}$ The issues minted in the second half of the 3rd century are well represented, whereas the early 2 nd century issues are more scarce. Here the issues are given with the dates and in the chronological order proposed by Giannikouri \& Stefanaki 2010: ${ }^{163}$

$\begin{array}{ll}\text { HI XVIII (c.260/50-220/30), } & \text { HI XIX (c.210-190/85), } \\ 41 \text { coins } & 133 \text { coins } \\ \text { HI XVI }(c .250 / 40-210 / 00), & \text { HI XXII (end of 3rd } \\ 71 \text { coins } & \text { century-c. 175), 19 coins } \\ \text { HI XX (c. 230-220), 32 coins } & \text { HI XXI }(c .200-180), \\ & 32 \text { coins } \\ \text { HI XVII }(c .220-200), 60 \text { coins } & \text { HIXXVI, two coins }{ }^{164}\end{array}$

The issues minted in the middle and second half of the $3 \mathrm{rd}$ century make up just over half of the middle Hellenistic single finds from the sanctuary, 204 of the 390 bronze coins. Then comes the issue with the largest number of coins, HI XIX; 54 of the 79 coins whose type can be determined belong to its first part, ${ }^{165}$ and are thus likely to be from the last decade of the 3 rd century. This means that 258 of the 390 bronze coins date to the period c. 250-200. ${ }^{166}$ Issue XIX, type 2, dating after 200 , is represented by 25 coins. The next issue, HI XXII, dated from the end of the 3 rd century to c. 175, gives 19 coins and HI XXI 32 coins. The issues dated to the early 2 nd century are thus represented by only 76 coins. What we see is a steadily increasing number of (dropped?) coins down to $\mathrm{c}$.

discussion and further references.

160 Workmen engaged in the reconstruction would probably not bring spending money.

161 According to Ingvaldsen all documentation for this collection was lost in the Second World War, but the coins at Göttingen, all having the same patina, should have come from the same find location which must be the Asklepieion. For longer discussion see Ingvaldsen 2002, 57, n. 231, where he gives the total number of coins as $c .700$.

162 Ingvaldsen 2002, 57-58, hoard 36.

163 Giannikouri \& Stefanaki 2010, 450-452, 454-455, 457-460. Stefanaki informs me that the HI XXV issue (all coins in Göttingen) belongs to the mint of Halikarnassos, and should be disregarded.

164 Ingvaldsen 2002, 57. As the date of the last issue depends on the date of the Herakles/incuse and Apollo silver, it is disregarded here.

165 I arrived at these figures going through Ingvaldsen's catalogue of coins, issue XIX, pp. 324-343.

166 Fifty-four of the issue XIX coins are of undetermined type. See Ingvaldsen 2002, 324-343.
200, after which there is a marked decrease; this must surely be connected with the earthquake of 198. HI XXI is one of the largest bronze issues on Kos; as it began when the later part of HI XIX was being minted, it probably postdates the earthquake. The coins belonging to it do not reflect the size of the issue (there are more than those of the immediately preceding small issues, but still comparatively few) and they may come from the period after the reopening of the sanctuary.

The chronological pattern of the single bronze coins found in the Asklepieion thus vindicates the dates suggested by Giannikouri and Stefanaki for the bronze issues also present in IGCH 1320.

\section{The onomastic evidence (Fig. 2)}

\section{A comparison with other Koan issues}

As the two issues which are the subject of this article ran parallel to one another I will, in this part, treat them as one group. Nine of the 18 readable names in the two issues also appear in other coin issues presented in Ingvaldsen 2002 and Höghammar 2007 (discounting the very uncertain Archias). The appearance of a name in two or more different sources does not of course mean that they refer to the same person, particularly when patronymics are not recorded. Nevertheless, it can be valid to use homonymity in different coin issues as evidence for contemporaneity, for several reasons. One is that the names on the coins refer only to the men who were responsible for the minting of the issues, a very small set of persons. If one finds a group of names occurring in different issues which are, for other reasons, regarded as belonging to the same general period covering about one generation, it is highly likely that they refer to the same persons. One can also check how common or unusual a certain name is in the onomastic corpus of the polis concerned. If a name is both unusual and occurs in what appear to be contemporary sources, the likelihood that it refers to the same individual increases further. Style of lettering is a further clue: if the shape of the letters used for the same name in different issues is identical or near-identical, there is a possibility that the homonyms refer to one person using the services of the same die-engraver.

Two of the names, Aratos and Parmeniskos appear in $\mathrm{HI}$ XVI, a 3rd century bronze issue ending in c. 200. ${ }^{167}$ Hieron appears as one of the last but one pair of names in HI XII, also ending c. 200. A group of three names, Agesias, Eukrates and Parmeniskos, appears in the bronze issue HI XIX, dating to $c .210-190(/ 185)$ and comprising 21 names. Three names, Agesias, Kleufantos and Parmen[-iskos], appear in HI XXI (13 names in total), a bronze issue now dated to $c$. 200/195-

167 Some of the last coins in this issue show the later spelling of the ethnic, $\mathrm{K} \Omega \mathrm{I} \Omega \mathrm{N}$, and should thus not be earlier than c. 200 . 
180. ${ }^{168}$ The name Agesias also appears in Höghammar 2007, silver issues A and C. Another group of five(?) names, Agesias, Eudamos, Nikon, Kleo[-nymidas(?)], and Parme[-niskos(?)] occur in the Asklepios/incuse silver issue. ${ }^{169}$

The names appearing as homonyms in different issues are, on the whole, neither extremely unusual, nor very common and we can draw no particular conclusions from their frequency in the Koan onomastic corpus. ${ }^{170}$ There are two exceptions to this. The name Parmeniskos is so common that more than one magistrate with this name could well have been active even within a short period of time. The name Kleufantos is quite rare, so that homonymity should here be more significant (see discussion below).

The three issues which have the most names in common with the Herakles and Apollo issues are HI XIX with three names, ${ }^{171} \mathrm{HI}$ XXI with three, one of which is rare, and the Asklepios/coiled snake in incuse silver issue with five(?). ${ }^{172} \mathrm{My}$ conclusion is that these issues are partly contemporary. ${ }^{173}$ The connection with the issues HI XIX and XXI would, if this

168 Giannikouri \& Stefanaki $(2010,452)$ date it 200-180, and Stefanaki gives 200/195-180, Stefanaki 2012. Ingvaldsen (2002, 149-151, 164) dates it $c .190-170$.

169 Kroll dated this issue, comprising 28 names, to the second half of the 2 nd century to the early 1 st century. In my opinion it belongs to the first half of the 2nd century (see Höghammar 2010b, 271-273).

170 The corpus of Koan inscriptions for the Hellenistic period is second only to that of Athens and allows one to judge reasonably well whether a name is unusual or not. The most recent source for Koan names is the Packard Humanities Institute's database for inscriptions, http://epigraphy.packhum.org/inscriptions/, which I have used (20 November 2009). As some inscriptions are difficult to date I have used the whole Koan corpus for my search of homonyms. This means that the persons may date to any period of antiquity. All entries known to refer to the same individual are counted as one. If the number of entries is ten or fewer I regard the name as uncommon, if there are eleven to 20 it is fairly common, and if there are more than $20 \mathrm{I}$ regard it as common (the most frequent names can appear up to 50 times). For names on coins listed above, this procedure gives the following results: Aratos 15, Parmeniskos $c$. 50, Hieron 14, Agesias 15, Nikomedes twelve (eleven of the 22 entries refer to the same person), Kleufantos seven.

${ }^{171}$ Parmen[-iskos] is not complete on the hemidrachms, and its homonymity is thus not fully ascertained.

${ }^{172}$ Parme/n[-n/iskos] appears in a shortened form on both the hemidrachms and the Asklepios/incuse silver. Kleonymidas is complete on the hemidrachms, but we have only $\mathrm{K} \Lambda \mathrm{E} \Omega$ - in the Asklepios/incuse issue, where it could be another name.

${ }^{173}$ Head suggested that the Herakles/incuse drachms and the Asklepios/incuse silver were roughly contemporary. This was rejected by Kroll "... the names on the tetrobols [the Asklepios/incuse silver] do not correspond to names on any other Koan coinage, bronze or silver, indicating that when the tetrobols were minted, they were minted exclusively, without larger or smaller denominations. The incuse drachms must have been earlier than the tetrobols and, as Head plausibly deduced, were probably struck after $166 \mathrm{BC}$ in imitation of the restored incuse drachms of Rhodes." (Kroll 1964, 83). With the now enlarged group of names we can see that Kroll was mistaken. conclusion is correct, date the Herakles and Apollo silver in the 190s.

\section{A comparison with two inscriptions from 201/0 and $c .180$ respectively}

When comparing the names on the coins with names in inscriptions, I limit myself to those dating to the general period when the issues were minted, c. 200-170. ${ }^{174}$ As there is a large number of inscriptions, many of them containing long lists of names, from the period c. 210-170, one would expect to find homonyms in any of the four decades. ${ }^{175} \mathrm{I}$ have chosen to look at two inscriptions, PH 10 (=IG XII 4,1.75-77) and Pugliese-Carratelli 1963/64, no. 26 (=IG XII 4,1.104), both including an unusually large number of names. The first is from 201/0 and the second from $c .180$. PH $10,{ }^{176}$ with the names and patronymics of slightly more than 300 persons donating money to the war effort in 201/0, gives us a good review of the names of the Koan citizens likely to participate in public affairs and stand for office. The inscription is not complete, and the original total of donors is estimated at $c .400 .{ }^{177} \mathrm{It}$ is, however, the inscription which lists the largest number of adult Koans from the entire polis at a particular point in time that we have. The men were probably, at the time, heads of their oikos. Twelve of the 18 names on the coins occur in the inscription as proper names and/or as patronymics. ${ }^{178}$

More significant is perhaps that, in this small group of 18 names we have two donors with their respective fathers, Aratos, son of Kleufantos, and Parmeniskos, son of Hieron. ${ }^{179}$ The name Aratos is not particularly frequent on Kos and Kleufantos is rare (see n. 170. As the coins are roughly contemporary

\footnotetext{
174 Earlier or later parallels are here irrelevant to the question of a more exact dating of the issues.

175 The name of a young adult appearing in an inscription from the years around 200 could normally be expected to appear as a patronymic one generation later, $c$. 170. When a name appears as a patronymic the person whose name it was could, depending on the age of the person whose proper name it belongs to, be (long) dead.

176 The inscription is in the British Museum. It is also published as GIBM no. 343, SGDI III 1, no. 3624, Baker 1991, no. 50 and $I G$ XII 4,1 , nos. $75-77$. It was cut in three different copies. The stone in the BM gives most of the document; smaller fragments from the other copies are included in $I G$ XII 4,1, see nos 76-77.

177 Migeotte 1992, 154-160, and Migeotte 2000, 165-166.

178 Five appear both as a name and as a patronymic (Aristandros, Aristoboulos, Hieron, Kallippidas, Permeniskos), three just as patronymics (Kleufantos, Leukippos, Nikon) and three just as names (Agesias, Aratos, Eudamos). The status of one name (Eukrates) cannot be determined. 179 The same phenomenon occurs also on Kalymnos, where Kleufanes, son of Peisistratos, is listed as a donor in the inscription TC 85, dated $c$. 205-200; both names also appear on the Kalymnian issues of "Persic" / Microasiatic weight silver, and most probably refer to the same persons. The Kalymnian example would then show that father and adult son could be active as moneyers at the same time. For detailed arguments see Höghammar 2007, 91.
} 
(c. 200-170) with the inscription, it is probable that Aratos and Kleufantos on the coins are identical with the donor and his father. The second donor, Parmeniskos, has a very common name, but the name of his father, Hieron, is not particularly frequent. These homonyms may refer to the same individuals, but in this case it is more uncertain. The donors in PH 10 were adults, meaning that their fathers were old in $201 / 0 .{ }^{180}$ Should the four homonyms on the coins be identical with those in the inscription, this almost certainly excludes the possibility that the fathers were active in state affairs 20 to 30 years later, as they then most probably would have died, or, if still alive, be 70-80 years old and, most likely, not active in public affairs.

The second inscription, Pugliese-Caratelli 1963/64, no. $26,{ }^{181}$ from the deme of Halasarna, dates to $c .180$ and lists about 180 citizens who had the right to participate in the hiera of the deme. They are given with patronymics, their mother's name and her patronymic. Up to four generations in the same family occur. Unlike PH 10, it does not cover the citizens of the whole of Kos, ${ }^{182}$ but Halasarna was a populous and important deme, and one would expect several correspondences with coins of about the same date. The pattern is, with one exception, similar to that for PH 10. There are eleven homonyms, five as both name and patronymic, four only as a patronymic, and two only as a name. A Thrasyandros son of Agesias is found in the lists, ${ }^{183}$ and both names also appear on the coins. This name and patronymic also occur in another decree, Segre 1993 ED 146, dated by Habicht to $c .200 .{ }^{184}$ As the name Thrasyandros is rare (ten entries) this is probably the same man. This shows us that Thrasyandros was an adult by $c$. 200 and an older man in $c .180$. Thrasyandros's father, Agesias, would then be either extremely old or dead. We cannot presume that he was active in public affairs. Also in this case it is probable that the homonyms in the two inscriptions and on the coins refer to the same persons and, if so, that the coins would be more or less contemporary with the inscription from c. 200 as Agesias's name on the coins show him taking an active part in the running of the polis.

The remaining homonyms, single names appearing both as names and patronymics, do not point in any particular direction. As the pattern for the single names is the same for

180 The normal age of marriage in ancient Greece was 30 years. A man's first son would thus normally be born after his father had turned 30 . The father would consequently have reached at least the age of 50 when his son was a grown man.

181 This is the same inscription as PH $367 / 68$ or $I G$ XII.4.1, nos. 103104.

182 Several of the persons, however, also appear in inscriptions from the deme of Isthmos.

183 Pugliese-Caratelli 1963/64, no. 26 BII.56-59.

184 Habicht 2004, 65, Appendix 1, see "Tharsikrates". both inscriptions, no direct conclusions can be drawn from the homonyms in them.

When we look at the combination of name and patronymic, there is a stronger connection with the earlier inscription. In the small group of 18 names from the coins four reappear in PH 10 as that of two donors with patronymics. Together with the third pair, appearing in another inscription from c. 200, they indicate a date at the very beginning of the 2 nd century for the two issues under discussion.

\section{The lettering $(P l s .7,8)$}

Coins are, apart from all else, also objects displaying art. As such they have iconographic and stylistic traits. Working in one or another style was a matter of choice, whether conscious or subconscious. A description of the style used is therefore part of the basic description of a coin just like a description of its other constituent traits. In the Hellenistic period many different styles existed both simultaneously and over time. The same stylistic traits do not necessarily mean contemporaneity and different styles may be contemporaneous. Therefore any interpretation of stylistic traits must be made with care. This is also true for stylistic comparisons of the lettering. All the same the results of a stylistic analysis form part of the basic description of an issue as the motives on all coins display stylistic traits. An analysis will show whether the stylistic traits observed on the coins under discussion also appear in other issues from the period/s concerned. Together with a careful description of the iconographic details, the study of a certain coin's style also forms the basis for stamp identification.

The lettering on the Apollo/lyre hemidrachm with the name Diotimos, no. 36 (all letters are clear) is close to that on certain coins on two other issues: the first two coins from the preceding issue of young Herakles/crab, club hemidrachms (HI XIII), with name Diogenes, ${ }^{185}$ and the "Persic" weight hemidrachm, KH 2007, C6 also with the name Diogenes (Pl. 7). Diotimos and Diogenes allow an exact comparison of their first three letters, and most of the letters in the ethnic $(\mathrm{K} \Omega \mathrm{ION}$ on the young Herakles hemidrachms, $\mathrm{K} \Omega \mathrm{I}$ on the "Persic" weight hemidrachm, and $\mathrm{K} \Omega \mathrm{I} \Omega \mathrm{N}$ on the Apollo hemidrachms) can also be compared.

Firstly, the more general characteristics. On the Diotimos hemidrachm the strokes are fairly thick, ${ }^{186}$ ending in dots, or, on the iota, short and thick transverse bars. Delta, $m u$ and $n u$ are broad. Omikron is very small and omega just about as large

\footnotetext{
185 Athens NM, nos. 169 and 172 from the $I G C H 1308$ hoard. This hoard contains 17 coins with the name of Diogenes showing different styles of lettering. Probably several die-cutters worked with him during his period of office.

186 The contours of the letters appear to be somewhat blurred, indicating that the die was well used when this coin was struck.
} 
as the other letters. On the three Diogenes coins the strokes are fairly thick on $\mathrm{KH} 2007 \mathrm{C} 6$, and thinner on the two young Herakles/crab, club hemidrachms. The strokes end in dots.

Specific similarities: The kappas of the ethnic on the Diotimos coin and on the hemidrachm Athens NM 172 are close. The vertical stroke leans outwards and goes well below the end of the lower oblique stroke. The omega is open and almost of the same size as the other letters. The stroke of the iota is thick. The $n u$ in both is very broad and the oblique stroke ends well above the bottom end of the right vertical stroke. The most interesting comparison, however, is between the second and third letters of the name, IO. The first letter is followed by a longish iota and a very small, highly placed omikron. The following letters are broad and well spaced. As many details are close, the dies may have been cut by the same die-engraver.

Two other coins show close similarities in the style of the lettering: the Apollo hemidrachm no. 3 and Höghammar 2007 C 5 (probably dating to 201-200), both with the name Agesias (Pl. 8). ${ }^{187}$ They share the same general characteristics with broad strokes ending either in thick "pellets", or in short broad cross-strokes, or something in between. This style is dissimilar to the lettering on the other coins in the Höghammar $2007 \mathrm{C}$ issue, but resembles that on some other coins in the Apollo issue, my group A with the reverse $n u$ (see above). The letters in both issues have a clumsy look.

Some letters also show specific similarities. The kappa has short oblique strokes and the omega consists of an open half circle with, below it, a clearly discontinuous horizontal line ending in marked cross-strokes. ${ }^{188}$ The lettering of the name is not as easy to compare as the reverse of the Apollo coin is quite worn, but the general shape of the letters can be made out. All the letters in the name on the two coins resemble one another closely. Alpha, gamma, eta and sigma are broad and of just about the same height. The similarities are such that in my opinion the dies may well have been cut by the same hand.

\footnotetext{
187 Agesias occurs 15 times in the PHI database. The name is thus neither rare nor common.

188 Three other Apollo hemidrachms (nos. 5, 10 and 29) and one Herakles/incuse drachm (no. 32) show this type of omega. The die-cutter of the hemidrachms is the same who cuts a reversed $n u$. This type of omega also appears in the Asklepios/incuse issue, for instance ANS 1960.170337, $1960.170344,1960.170346-48,1960.170352$. I have also looked at the lettering on photos of about 80 coins belonging to the bronze issue $\mathrm{HI}$ XXI, head of Asklepios/snakestaff, which is dated c. 200-180 and found no parallel (the Bourinna hoard, Toulanta-Parisidou 2006- Kos museum coins, BN Paris, Münzkabinett Berlin, the Ashmolean, Oxford and a few coins from the BM London). This is well under half of the known coin coins in this issue, but it suggests that this particular shape of the omega was rather unusual as I have found no such shape among other coins examined.
}

Stylistic comparisons of the obverse motif $(P l .9)$

The obverse die $\mathrm{O} 10$ of the young Herakles/incuse issue shows close stylistic similarities with the Herakles head on Höghammar 2007 A6, probably dating to 201-200. The locks of the lion's mane are arranged in the same way and the lion-skin ends just below the Adam's apple on the throat. The ears have just about the same shape, a thick oval. In both the line above the eye, starting at the nose ridge is roughly horizontal with a sharp downwards bend $\left(\right.$ about $90^{\circ}$ ) at the outer end of the eye, then going down. Also the wide-open eye with a thick marked lower eye line is very similar. The forehead shows a broken profile with a big bulge at the eyebrows. Also the profile of the nose shows a marked bulge. These specific traits appear in both issues. The horizontal line of the nose, from the tip to where the nostrils join the cheeks, has the same shape in both dies, as do the lips. One should be careful when making stylistic comparisons, but here the similarities seen in so many of the details indicate that it was the same person cutting the dies.

The many similarities with the Höghammar 2007 issues A and C with a suggested date of $c .200$ are noteworthy. In issue $\mathrm{A}$ issue we have the same name, Agesias, and the stylistic closeness demonstrated above. There is also the appearance of a square incuse in coin $\mathrm{A}$ 9. In issue $\mathrm{C}$ we have the similarity of the lettering, the name Agesias, and the appearance of the control letter A. It appears as if Höghammar 2007 issues A and $\mathrm{C}$ may well have been minted close in time to the Herakles/incuse, Apollo/lyre issues.

\section{THE DATING—SUMMARY AND CONCLUSION}

Until the 1990s the view that the issues belonged to the middle or the late 2 nd century prevailed. The examination of the arguments presented for these datings shows that the basis was erroneous. In their discussions, Ashton in the late 1990s, and Ingvaldsen in 2002 assume that the Koan plinthophoroi must imitate the Rhodian and that they thus have to be somewhat later. As both Requier and Ingvaldsen now agree that Koan silver with a shallow square incuse (some examples in HI XIV), was minted in an intermediate technique already by the 3rd century and we have a plinthophoric coin, Höghammar 2007 A9, dated probably c. 200, this assumption is most likely mistaken. ${ }^{189}$

The heavier weight standard of the Koan plinthophoric issue as compared to the Rhodian suggests that it is the earlier. Both it and the diameter of the flan indicate that the two is-

\footnotetext{
189 Even should the Koan Herakles/incuse drachms imitate the Rhodian plinthophoric issues, the present dating of the latter to the mid-190s allows a date in the same decade for the Koan issue.
} 
sues were minted quite soon after the ending of HI XII and XIII in c. 200.

Their appearance in $I G C H 1320$ puts the two issues in a context of Koan and Kalymnian silver and bronze dating to the middle to late 3 rd century/c. 200. The latest externally dated coins in the hoard are the two Rhodian hemidrachms which now, with Meadows's new dating of the Mektepini hoard, most probably are to be dated c. 190. Two coins belonging to the bronze issue HI XIX, also represented in the hoard, were found on the agora of Athens in two different datable contexts, both support a dating at the end of the 3rd/ beginning of the 2 nd century for this issue.

Almost 400 bronze coins from the 3rd and the early 2nd century were found in the German excavations of the Asklepieion. The coins dating c. 250-200 are far more numerous than those dated to the early 2 nd century. The best explanation is the earthquake of 198 which must have cut the number of visitors to the Asklepieion in the 190s drastically. This agrees with and strengthens the dating suggested by Giannikouri and Stefanaki for the bronze issues also present in IGCH 1320.

Several names show probable connections with other issues. Three to five homonyms occur in issues HI XIX ( $c$. 210-190/80), HI XXI (c. 200/195-180) and the Asklepios/ incuse silver issue.

The inscription PH 10 dating to 201/0 has two donors with their respective patronymics whose names are also found on the coins. A third homonymic name and patronymic is found in two other inscriptions, one dating to $c .200$ and one to $c .180$. As the name, Thrasyandros, is rare, both probably refer to the same man; in the first he would be a grown man, in the second an older man. His old age in $c .180$ excludes his father being an active moneyer at that time. Should the homonyms refer to the same persons this is a strong indication of a date close to $c .200$ for the issues.

Stylistic traits in the Herakles head and in the lettering find close parallels in other Koan issues from c. 200, indicating that the same die-cutters may have been at work.

Thus, technical, hoard and onomastic evidence point to a dating in the 190s. This is supported by circumstantial and stylistic indications also agreeing with a date in that decade. My conclusion is that, on present evidence, the issues should be dated to the 190 s.

\section{Historical events c. 200 and in the early 2 nd century}

We know from inscriptions that the Koans were heavily involved in the war against king Philip V of Macedonia in 201/00 and that he attacked the island and landed troops there. The Koans repelled him and we see from the inscriptions the effort this involved and the pride they took in their success. In this war the Koans were formally allied to Rhodes and participated with their own ships in the sea-war. The impression given by the inscriptions is that the war taxed the resources of Kos and Kalymnos heavily. ${ }^{190}$ The Kalymnians also appear to have been successful in their struggle against Philip V. Somewhat earlier, in the decade c. 220-210, they had been incorporated into the polis of the Koans. ${ }^{191}$ During the war Kalymnos was briefly separated from, and then reincorporated into the Koan state, ${ }^{192}$ probably as early as the autumn of 201 and hardly later than the spring of 200 when Philip V had returned to Macedonia. Earlier, during most of the 3rd century, the Kalymnians had been under Ptolemaic hegemony. ${ }^{193}$

By 200 Philip V had taken Ephesos, Samos and Miletos in Ionia. In Caria he had captured the coastal poleis Iasos and Bargylia north-east of Kos. He controlled Nisyros just south of the island and had conquered all or most of the Rhodian Peraia as well as several inland poleis in Caria. Even after his return to Macedonia his military presence in the region was strong. Iasos and Bargylia were held by Macedonian troops until 197-196. The Rhodians launched a campaign to reconquer the Peraia between 201 and $198 .{ }^{194}$ As part of the anti-Macedonian alliance the Koans must have continued their war efforts after 200. The deposit $I G C H 1320$ found on Kalymnos with its mixed contents of Koan, Kalymnian and Rhodian coins could reflect an alliance where otherwise strictly national coins have been brought together.

The honorary statue of Flamininus, commander of the Roman forces in Greece, voted by the Koan demos and erected in the Asklepieion, strengthens the picture of continued Koan involvement in the war which ended with the defeat of Philip $\mathrm{V}$ at Kynoskephalai in 197 and the formal peace in 196. The statue was erected when Flamininus was consul ( $\sigma \tau p \alpha \tau \eta \gamma o \dot{s}$ ปँ $\pi \alpha \tau$ ) ), i.e. not earlier than 198, and the reason given is his aretê and goodness towards the demos of the Koans, the allies and the Greeks. The mention of allies ( $\sigma \nu \mu \mu \dot{\alpha} \times$ os $_{\text {) suggests that }}$ the Koans were still at war. ${ }^{195}$

In 198, the south-eastern Aegean was hit by a devastating earthquake, Kos being one of many poleis affected. In the 190s

190 Sherwin-White 1978, 120-124; Baker 1991, 30-68; $S I G^{3} 569.8-$ 10, 12-15, 33-34. See also, for Kos, PH 10, and for Kalymnos, Segre 1944-1945, no. 85, both collections of money for war purposes.

191 Habicht 2007, 140-141.

192 Sherwin-White 1978, 124-129; Holleaux, EE IV, 222-224, 292293

193 Sherwin-White 1978, 114-121.

194 Ma 2000, 76-81 with further references.

195 Höghammar 1993, 155, cat. no. 45 with further references. 
and later, the state and private individuals must have struggled to rebuild public buildings and private housing. ${ }^{196}$

In 197, presumably using the opportunity provided by the destruction caused by the earthquake, Antiochos III's fleet advanced along the western seaboard of Asia Minor and took control over many Greek cities in the area. The Rhodians allowed him passage after negotiations in which he promised not to disturb Rhodes or any Rhodian allies. The kingdom of Pergamon was, however, drastically reduced. ${ }^{197}$ The Koans, as allies of Rhodes, do not appear to have been affected directly by Antiochos's advance and probably concentrated on rebuilding their polis.

In 192, war broke out again, this time between Antiochos and an alliance formed by Rhodes, Pergamon and Rome. The Koans participated in this conflict which ended in 189; together with the Rhodians they fought at the battle of Samos, where only seven ships, two Koan and five Rhodian, escaped disaster. ${ }^{198}$ The peace of Apamea settled the war in 188.

The Koans must have had a standing navy in this period as the liturgy of trierarchos is often mentioned in contemporary inscriptions. ${ }^{199}$ We also know that there was a Koan nauarchos, i.e. an admiral. ${ }^{200}$

In the 180 s the Koans probably took part in yet another war, that of king Eumenes II against the Gauls and Bithynia, fought 186-183. Several Koan inscriptions as well as the architecture of the rebuilt Asklepieion show close contacts between Kos and Pergamon. The new large temple on its uppermost terrace could have been a replica of a Pergamene original donated by Eumenes II. ${ }^{201}$ Three inscriptions taken together make a strong case for a Koan war in this decade. The first two concern Eumenes II. An inscription in the Asklepieion shows that there was a priestess of king Eumenes II on Kos,

\footnotetext{
196 Justinus, who probably lived in the later 2 nd to early 3 rd century AD, wrote: "That same year [198 BC] there was an earthquake between the islands of Thera and Therasia" ... "Also, on that day, in Asia, the same earthquake struck Rhodes and many other cities, causing catastrophic damage as it levelled buildings and swallowing some cities whole" (Justinus 30.4). A Koan inscription dating to 196 (ED 178, 11. 31-32 in Segre 1993) mentions an earthquake which has taken place, presumably the same one.

197 Livius 33.19-20; Ma 2000, 82-92.

198 Livius 37.11; Sherwin-White 131-132.

199 As pointed out by Parker and Obbink, the existence of the liturgy of trierarchia, i.e. the provision of money for, and supervision of, the building of a warship, is attested in documents concerning the sale of priesthoods. Eight include mention of a trierarchia and date from the early 3 rd to the 1 st century. The clause mentioning trierarchia concerns the liturgies from which the incumbents of the priesthoods could not expect to be excepted. As the trierarchy occurs in almost half of this group of inscriptions (while others are fragmentary and lack the part concerning this clause), it should be regarded as one of the most important liturgies. Parker \& Obbink 2000, 415-449; 2001a, 229-252; 2001b, 253-275.

200 Sherwin-White 1978, 209.

201 Schwandner 1990a, 93; 1990b, 43, n. 13; Höghammar 1993, 25.
}

and another inscription tells us of a cult of Eumenes Soter (the Saviour). ${ }^{202}$ The fact that Eumenes II had an official cult in the independent polis of Kos and was hailed as Soter by the Koans points to a potentially grave danger which he helped avert. ${ }^{203}$ In his First Galatian War the king fought not only the Gauls, but also their ally, the Bithynian king, who had a strong navy. We know that this navy attacked the Pergamene coast, and from these inscriptions it appears that the Bithynian navy may also have threatened Kos. The third inscription is an epidosis, a list of contributors to a collection of money to help protect the polis and the fortified places. ${ }^{204}$ The editors, Hallof \& Habicht, concluded that the Koans were at war and dated the inscription to $180 / 175$. It could, however, be just a little earlier, $c .185-180$, this fits the onomastic evidence on which the chronological arguments are built. ${ }^{205}$ An attack by the Bithynian navy which the Pergamene king helped avert would fit the evidence of all three inscriptions and the picture we have of close and cordial relations between Kos and Pergamon in the 180s.

The two following decades appear to have been more peaceful as the Koans, like the Rhodians, remained neutral in the Third Macedonian War, 171-168. As this war was fought on the Greek mainland it did not threaten the Koans directly.

The inscriptions show that the Koans were as heavily involved in the international struggles in this region as the Rhodians. Their contribution was not on the same scale since Kos was a smaller polis, but proportionately their involvement and its effect on their economy would be similar. Ashton has shown that the production of Rhodian coins peaked in the period around 200. ${ }^{206}$ As compared with the previous period c. 230-205 the yearly output more than trebled, and was, in fact, the highest average ever for the Rhodians down to the start of the plinthophoroi. We should therefore expect a high output of Koan silver in the early 2 nd century to cover not only the expenses of the wars, but also the cost of reconstruction after the earthquake in 198. The rebuilding programme after the destruction would demand heavy expenditure, not

\footnotetext{
202 For the priestess see Höghammar 1993, no. 65 with further references. For the cult see Bosnakis \& Hallof 2005, 251-256, no. 23 or SEG 55, no. 926.

${ }^{203}$ Höghammar 1993, 22-26, esp. p. 24, n.17 and 18 for discussion of the use of the epithet soter in an official cult by an independent polis and for further references. According to both Habicht $(1970,168)$ and Gauthier $(1985,46)$ the introduction of a cult of a person was caused by an action of utmost importance to the polis concerned.

${ }^{204}$ Hallof \& Habicht 1998, no. 26, 157-161.

205 Höghammar 2004, 72-75.

206 The production was measured in the number of didrachm-equivalent dies. For an explanation of this measure see Ashton 2001, 92.
} 
short and peaked as for a war, but rather more evenly spread over a prolonged period of time. ${ }^{207}$

\section{Summary and conclusions}

Both issues under discussion were substantial and minted within a short period of time, not more than five to ten years. They were almost certainly larger in size than the 3rd century issues of Herakles drachms and hemidrachms (HI XII and XIII) and similar in intensity to that part of the bearded Herakles issue, HI XII, which I have connected with the First Kretan War starting in 205. When more exactly, in the early 2 nd century, was the Koan state in need of an output of this magnitude and of limited duration?

I see three possible occasions which could have prompted a need for the two issues, the later phase of the war against Philip V, i.e. after 201/0 down to 197; the war against Antiochos III 192-189, and Eumenes IIs' war against the Galatians and Bithynia 186-183 when the Bithynian navy sailed south, attacked Pergamon and, if I have interpreted the inscriptions correctly, threatened Kos. The last possibility, that they belong in the later 180 s, is less likely as different chronological indications point to a date in the first decade of the 2 nd century.

The first possibility is the years before the end of the Second Macedonian War in 197. As part of the anti-Macedonian alliance, the Koans were still at war after 201/0. The earthquake of 198 will have compounded the need for coinage, but I think it is less likely that the main purpose of these two issues was to finance the reconstruction work as they appear to have been struck over a very short period of time. Even if they were minted just after the earthquake, they must soon have been replaced with another issue. The rebuilding of Kos must have taken much longer than just a few years and for this we should expect an even larger issue minted over a long period of time (several decades).

The second possibility is that the issues were minted for and during the war against Antiochos as it took place not that long after the events and inscriptions of $c$. 200. The two Rhodian hemidrachms in the $I G C H 1320$ hoard with a dating of c. 190 support this date.

A date in the early 190 s seems preferable however, as the technical characteristics show a close relationship to the 3rd century issues and as there also seems to be a connection both to Koan inscriptions from c. 200 and to Kalymnos and the late 3 rd century Kalymnian issues (the Apollo/lyre motifs, the vertical legends and certain names). Should this be the case, the estimated size of the issues shows that the Koans continued to be heavily engaged in the Second Macedonian War, also after Philip's departure from the area. The successful defence against the Macedonian navy by both Koans and Kalymnians, and the reincorporation of Kalymnos may be part of the explanation for the unprecedented choice of the head of Apollo on the hemidrachms. Apollo Dalios was the main deity on Kalymnos, and to represent him on the Koan hemidrachms would be both an acknowledgement of the Kalymnian contribution in the war and a public recognition of their status as Koan citizens. A date in the early 190s could also explain the short period of striking for the two issues: one might suggest that the foreseeable heavily increased expenses over a prolonged period of time, caused by reconstruction work after the earthquake in 198, may have led to the withdrawal of both issues in order to start another lighter and larger issue in the form of the Asklepios/incuse coinage.

207 At present I think that the Asklepios/incuse silver was minted and used within Kos in the first half of the 2nd century to pay for the rebuilding after the earthquake. I cannot discuss this here as it would take up too much space. See Höghammar 2010b for some preliminary conclusions. 


\section{Appendix: \\ An estimate of the original number of obverse dies (Figs. 9-12)}

\author{
WARREN W. ESTY \& KERSTIN HÖGHAMMAR ${ }^{208}$
}

When discussing and contextualizing the output of money in ancient states, it is of great interest to have an idea of the approximate size of the original issues. When the data is too weak to support such calculations an estimation of the original number of dies based on the calculation of known dies can still be made. As the number of dies and coins in the two issues presented in this article are small ${ }^{209}$ we will limit ourselves to calculations of estimates of the number of original dies. The present samples present us with two clear difficulties. One problem is general: the identification of dies is not always easy, and different scholars may arrive at somewhat different results. ${ }^{210}$ Another is that, as the number of coins struck by each die, the duplicates, in the samples is very low, we cannot expect the point estimate of the original number of dies to be accurate. In spite of these difficulties the calculations, even on scanty data as here, provide us with some rather useful estimates. ${ }^{211}$

\section{The drachms (total number of listed coins in issue $=44)^{212}$}

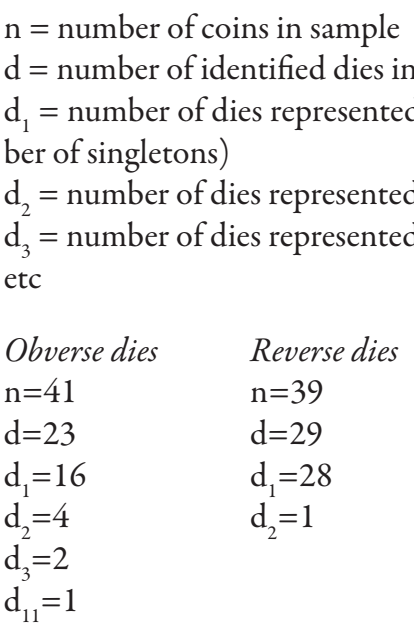

In the case of the drachms, it is clear that the eleven coins from one die-pair (coin nos. 15-25) entered the sample in a non-random manner. If estimation formulas are to be used we should reduce the count of the number of coins by the number of obvious non-random duplicates, ${ }^{213}$ in this case probably ten, but conservatively at least seven. Using seven, the number of coins in the sample of obverse dies is reduced from 41 to 34 with 23 different dies and 16 singletons.

The point estimate of the obverse die coverage is only $53 \%$ and an unreliable point estimate of the original number of dies is $71^{214}$ with an extremely wide "95\%" confidence interval of 39 to $139 .{ }^{215}$ This means that we think we have seen the dies responsible for about $53 \%$ of the coins produced and the unreliable estimate of the original number of obverse dies is 71 , but, with $95 \%$ confidence, it could be any figure from 39 to 139.

The reverse die coverage estimate is only $13 \%$ and a point estimate of the number of reverse dies can only be misleading because there are too few duplicates. Using Esty's 1978 article on estimating the number of dies when there are few duplicates, ${ }^{216}$ we can be $95 \%$ confident that there were at least 88 reverse dies and it is likely there were many more.

The main conclusion to be drawn is that the original number of obverse dies almost certainly was 39 or more, probably rather higher than 39, i.e. considerably more than the 23 dies

\footnotetext{
212 As there are some coins in such a bad condition that their dies cannot be identified, the listed number of coins is higher than the number of coins in the sample.

213 Esty 2006, 362.

214 Calculation according to Esty 2011, 46, formula 1.

215 Calculation according to Esty 2006, 360, formula 4.

216 Esty 1978, 302.
} 


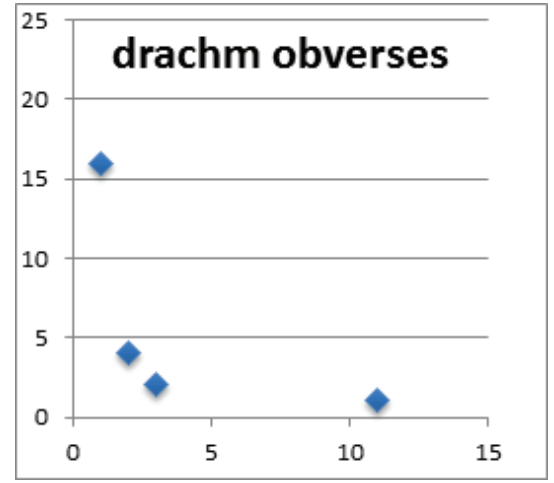

Fig. 9. Obverse die frequencies, drachms.

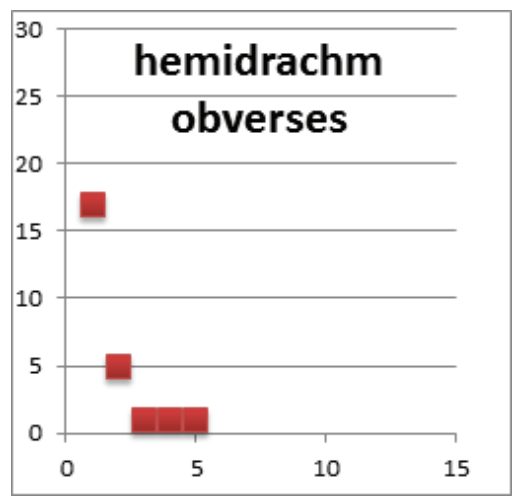

Fig. 11. Obverse die frequencies, hemidrachms.

known from the sample. This strongly indicates that the issue originally was very much larger than what one would expect from the small number of coins known to us.

\section{The hemidrachms (total number of listed coins $=45$ )}

$\begin{array}{ll}\text { Obverse dies } & \text { Reverse dies } \\ \mathrm{n}=39 & \mathrm{n}=38 \\ \mathrm{~d}=25 & \mathrm{~d}=36 \\ \mathrm{~d}_{1}=17 & \mathrm{~d}_{1}=34 \\ \mathrm{~d}_{2}=5(\text { or } 7) & \mathrm{d}_{2}=2 \\ \mathrm{~d}_{3}=1 & \\ \left.\mathrm{~d}_{4}=1 \text { (or } 0\right) & \\ \mathrm{d}_{5}=1 & \end{array}$

The obverse die coverage point estimate is $56 \%$, that is, we think we have seen the dies responsible for about $56 \%$ of the

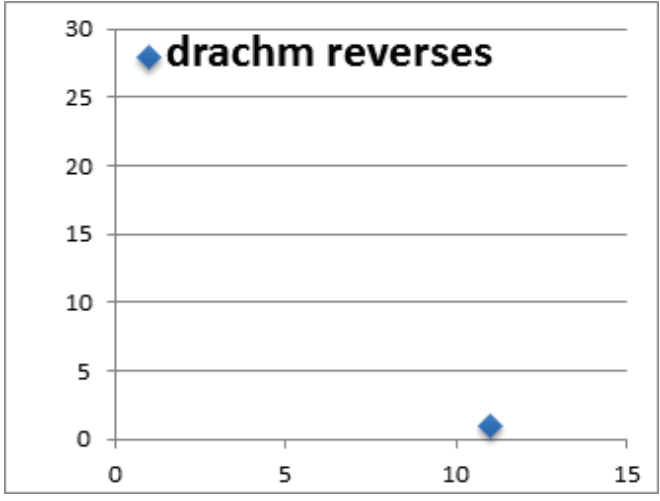

Fig. 10. Reverse die frequencies, drachms.

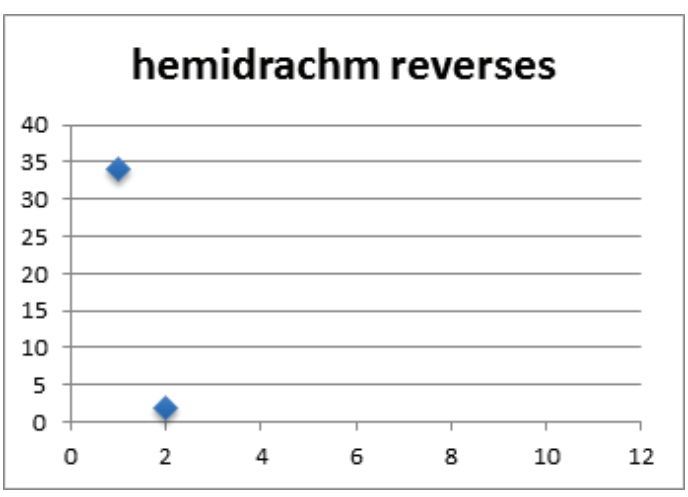

Fig. 12. Reverse die frequencies, hemidrachms.

coins produced. ${ }^{217}$ The wide range of the obverse die coverage point estimate shows the uncertainty of the estimate. The unreliable point estimate of the original number of obverse dies is 70 , with an, again very wide, "95\%" confidence interval of 40 to 125 . This means that, almost certainly, the lowest number of obverse dies was 40, but most likely it was considerably higher. Again this figure can be compared (and contrasted) with the 25 dies known from the sample.

The reverse die coverage estimate is only $11 \%$ and again a point estimate of the number of reverse dies can only be misleading because there are too few duplicates. We can be $95 \%$ confident there were at least 103 reverse dies and it is likely there many more. ${ }^{218}$

Just as for the drachms the conclusion is that, almost certainly, the issue was much larger than what could at first be expected from the small number of coins known to us.

217 Calculation according to Esty 2006, 360, formula 5.

218 Esty 1978, 302. 


\section{Bibliography}

Apostolou, E. 2002. 'Rhodes hellénistique. Les trésors et la circulation monetaire', Eulimene 3, 117-182.

Ashton, R.H.J. 1996. 'A hoard of Coan coins', NC 156, 278-279.

Ashton, R.H.J. 1998. 'The pseudo-Rhodian drachms of Kos', NC 158, 223-228.

Ashton, R.H.J. 2001 'The coinage of Rhodes 408-c. 190 BC', in Money and its uses in the ancient Greek world, eds. A. Meadows \& K. Shipton, Oxford, 79-115.

Ashton, R.H.J. 2013 'The Hellenistic world: The cities of mainland Greece and Asia Minor', The Oxford handbook of Greek and Roman coinage, ed. W.E. Metcalf, 191-210.

Baker, P. 1991. Cos et Calymna 205-200 a.C. Esprit civique et défense nationale, Quebec.

Bosnakis, D. \& Hallof, K. 2005. 'Alte und neue Inschriften aus Kos II', Chiron 35, 219-272.

De Callataÿ, F. 2005. 'A quantitative survey of Hellenistic coinages: recent achievements', in Making, moving and managing: the new world of ancient economics, 323-31 BC, eds. Z. Archibald, J.K. Davies \& V. Gabrielsen, Oxford, 73-91.

Esty, W.W. 1978. 'Estimation of the number of dies used in a coinage when the sample has few duplicates', Numismatic Circular, June, 302.

Esty, W.W. 2006. 'How to estimate the original number of dies and the coverage of a sample', NC 166, 359-364.

Esty, W.W. 2011. 'The geometric model for estimating the number of dies', in Quantifying monetary supplies in Greco-Roman times (= Pragmateiai 19), ed. F. de Callataÿ, Bari, 43-58.

Finkielsztejn, G. 2001. Chronologie détaillée et revisée des eponymes amphoriques rhodiens, de 270 à 108 av. J.-C. environ. Premier bilan (BAR-IS, 990), Oxford.

Gargali, N. 2009. 'Coins from a Hellenistic cemetery on Kalymna, and new light on the coinage of Kos in the second century BC', NC 169, 29-37.

Gauthier, P. 1985. Les cités grecques et leurs bienfaiteurs (BCH Suppl., 12), Athens \& Paris.

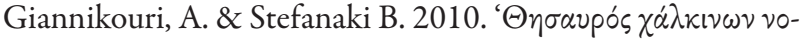

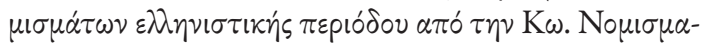

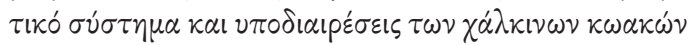

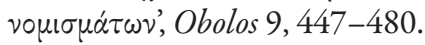

Giannikouri, A. \& Stefanaki V. 2011 'La circulation monétaire dans la Dodécanèse de l'époque archaïque à l'époque hellénistique: les exemples de Cos et de Calymna', in Nomisma. La circulation monétaire dans le monde grec antique. Actes du colloque international, Athènes, 14-17 avril 2010, eds. T. Faucher, M.-Chr. Marcellesi \& O. Picard (BCH Suppl., 53), 343-366.

GIBM II. The collection of ancient Greek inscriptions in the British Museum. Part II, ed. C.T. Newton, Oxford 1883.

Grace, V. 1985. 'The Middle Stoa dated by amphora stamps', Hesperia 54, 1-54.

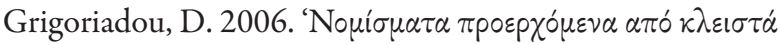

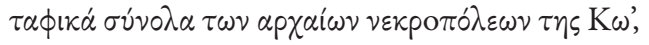
Obolos 8, 125-142.

Habicht, C. 1956. Gottmenschentum und griechische Städte (Zetemata. Monographien zu Klassischen Altertumswissenschaft, 14) München (reprint 1970).

Habicht, C. 2004. 'The dating of the Koan monarchoi', in The Hellenistic polis of Kos. State, economy and culture. Proceedings of an International Seminar organized by the Department of Archaeology and Ancient History, Uppsala University, 11-13 May, 2000 (Boreas. Uppsala studies in ancient Mediterranean and Near Eastern civilizations, 28), Uppsala, 61-67.

Habicht, C. 2007. 'Neues zur hellenistischen Geschichte von Kos', Chiron 37, 2007, 123-152.

Hallof, L. \& K. \& C. Habicht, 1998. 'Aus der Arbeit der "Inscriptiones Graecae” III. Unedierte koische Epidosis-Listen', Chiron 28, 143-162.

Herzog, R. 1899. Koische Forschungen und Funde, Leipzig. Herzog, R. \& P. Schazman 1932. Kos I. Asklepieion, Berlin.

Holleaux, M. 1952. Études d'épigraphie et d'histoire grecque IV, Paris.

Höghammar, K. 1993. Sculpture and society. A study of the connection between the free-standing sculpture and society on Kos in the Hellenistic and Augustan periods (Boreas. Uppsala studies in ancient Mediterranean and Near Eastern civilizations, 23), Uppsala. 
Höghammar, K. 2004. 'The inscribed, cylindrical, funerary altars: questions of date and stylistic development', in The Hellenistic polis of Kos. State, economy and culture. Proceedings of an International Seminar organized by the Department of Archaeology and Ancient History, Uppsala University, 11-13 May, 2000 (Boreas. Uppsala studies in ancient Mediterranean and Near Eastern civilizations, 28), Uppsala, 69-81.

Höghammar, K. 2006. 'A small hoard of Koan drachms and hemidrachms from c. 200 B.C. ', NC 166, 378-380.

Höghammar, K. 2007. 'A group of Koan issues from c. 200 BC', NC 167, 79-92.

Höghammar, K. 2010a. 'The Hellenistic silver coinage of Kalymnos', Obolos 9, 495-526

Höghammar, K. 2010b. 'Long-term resilience: the reconstruction of the ancient Greek polis of Kos after earthquakes in the period c. $200 \mathrm{BCE}$ to $c .200 \mathrm{CE}$, in The urban mind. Cultural and environmental dynamics (Studies in global archaeology, 15), eds. P.J.J. Sinclair, G.C. Nordquist, F. Herschend \& C. Isendahl, Uppsala, 261-275.

Höghammar, K. 2013. 'An ending in war. The Koan late third century Herakles silver', in Perspectives on ancient Greece. Papers in celebration of the 60th anniversary of the Swedish Institute at Athens (ActaAth- $8^{\circ}$, 22), ed. A.-L. Schallin, Stockholm, 191-230.

Hoover, O.D. 2008. 'Countermarks on Seleucid and foreign silver coins' (App. 4a), 'Countermarks on Seleucid and foreign bronze coins' (App. 4b), in Seleucid coins: A comprehensive catalogue, Part II. Seleucos IV through Antichus XIII, Vol. II. Appendices, indices, and plates, eds. A. Houghton, C. Lorber \& O. Hoover, New York \& Lancaster, 157-208.

Hoover, O.D. 2010. 'Commerce ("Pamphylia or Cilicia” hoard), 2000 (CH 10, 292)', in Coin hoards X. Greek hoards, eds. O. Hoover, A. Meadows \& U. Wartenberg, New York, 129-152.

Howgego, C.J. 1985. Greek imperial countermarks. Studies in the provincial coinage of the Roman empire (Royal Numismatic Society, Special publications, 17), London.

Howgego, C.J. 1995. Ancient history from coins, London.

$I G$ XII.4.1 = Inscriptiones Graecae XII. Insularum maris Aegae praeter Delum, IV. Inscriptionis Coi Calymnae insularum milesiarum, I. Inscriptiones Coi insula. Decreta. Epistulae. Edicta. Tituli sacri, eds. D. Bosnakis, K. Hallof \& K. Rigsby, Berlin 2010.
Iossif, P.P. 2011. 'Seleucid "eagles” from Tyre and Sidon: preliminary results of a die-study', in Proceedings of the XIVth International Numismatic Congress, Glasgow 2009, ed. N. Holmes, Glasgow, 213-229.

Ingvaldsen, H. 2002. Cos - coinage and society. The chronology and function of a city-state coinage in the Classical and Hellenistic period, c. 390-170 BC (Acta Humaniora, 149), Oslo.

Jenkins, G.K. 1989. 'Rhodian plinthophoroi - a sketch', in Kraay-Morkholm essays. Numismatic studies in memory of C.M. Kraay and O. Morkholm (Numismatica Lovaniensia, 10), ed. G. Le Rider, Louvain-laNeuve, 101-119.

Kabus-Preisshofen, R. 1989. Die hellenistische Plastik der Insel Kos (AM-BH, 14), Berlin.

Klee, T. 1918. Zur Geschichte der gymnischen Agone in griechischen Festen, Leipzig \& Berlin.

Kroll, J. 1964. 'The Late Hellenistic tetrobols of Kos', ANSMN 11, 81-117.

Kroll, J. 1993. The Athenian Agora XXIV. The Greek coins, Princeton, NJ.

Ma, J. 2000. Antiochos III and the cities of western Asia Minor, Oxford.

Magnetto, A., ed. 2008. L'arbitrato di Rodi fra Samo e Priene, Pisa.

Meadows, A. 2001. 'Money, freedom and empire in the Hellenistic world', in Money and its uses in the ancient Greek world, eds. A. Meadows \& K. Shipton, Oxford, 53-63.

Meadows, A. 2002. In R.H.J. Ashton, N. Hardwick, P. Kinns, K. Konuk, A.R. Meadows, 'The Pixodarus hoard (CH 9.421)', in Coin hoards Volume IX. Greek hoards (Royal Numismatic Society, Special publications, 35), eds. A. Meadows \& U. Wartenberg, London,159-243.

Meadows, A. 2009. 'The eras of Pamphylia and the Seleucid invasions of Asia Minor', AJN 21, 51-88.

Migeotte, L. 1992. Les souscriptions publiques dans les cités grecques (= Hautes études du monde gréco-romain 17), Genève.

Migeotte, L. 2000. 'Retour à la grande souscription publique de Cos des années 205-201 avant J.-C., in Tiщai

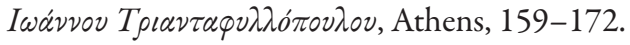

Milne, J.G. 1939. Greek and Roman coins and the study of history, London. 
Mørkholm, O. 1983. 'The life of dies in the Hellenistic period, in Studies in numismatic method presented to Philip Grierson, eds. C.N.L. Brooke, B.H.I. Stewart, J.G. Pollard, \& T.R. Volk, Cambridge, 11-17, Pls. $2-4$.

Mørkholm, O. 1991. Early Hellenistic coinage. From the accession of Alexander to the peace of Apamea (336-188 B.C.), Cambridge.

Noe, S.P. $1937^{2}$. A bibliography of Greek coin hoards (Numismatic notes and monographs, 78), New York.

Parker, R. \& D. Obbink 2000. 'Aus der Arbeit der "Inscriptiones Graecae" VI. Sales of priesthoods on Cos I', Chiron 30, 415-449.

Parker, R. \& D. Obbink 2001a. 'Aus der Arbeit der "Inscriptiones Graecae" VII. Sales of priesthoods on Cos II', Chiron 31, 2001, 229-252.

Parker, R. \& Obbink, D. 2001b. 'Aus der Arbeit der "Inscriptiones Graecae" VIII. Three further inscriptions concerning Koan cults', Chiron 31, 253-275.

Paton, W.R. \& E.L. Hicks 1891. The inscriptions of Cos, Oxford 1891 (reprint Georg Olms Verlag 1990).

Pugliese Carratelli, G. 1963-1964. 'Il damos coo di Isthmos', ASAtene 41-42, N.S. 25-26, 147-202.

Requier, P. 1996. 'Les premiers tetradrachms hellenistiques de Cos', Revue Suisse de Numismatique 75, 53-64, Pls. 7-12.

Robert, L. 1967. Monnaies grecques. Types, legends, magistrates monétaires et geographie (= Hautes Études Numismatiques 2), Genève/Paris.

Robinson, E.S.G. 1936. 'British Museum acquisitions for the years 1933-1934', NC 16, 169-201.

Sawaya, Z. 2005. 'Les Tétradrachms Séleucides à l'Aigle de Bérytos', NC 165, 99-124.
Schwandner, E.-L. 1990a. 'Beobachtungen zur hellenistischen Tempelarchitektur von Pergamon', in Hermogenes und die hochhellenistische Architektur. Internazionales Kolloquium in Berlin vom 28. bis 29. Juli 1988 im Rabmen des XIII Internationalen Kongresses für Klassische Archäologie, eds. W. Hoepfner \& E.-L. Schwandner, Mainz-am-Rhein, 85-102.

Schwandner, E.-L. 1990b. 'Ein monumentaler dorischer Marmortempel in Pergamon', in Phyromachosprobleme. Mit einen Anhang zur Datierung des grossen Altares von Pergamon (RM-EH, 31), ed. B. Andreae, Mainz, 41-43.

$S E G=$ Supplementum Epigraphicum Graecum.

Segre, M. 1944-1945 (pr. 1952). Tituli Calymnii (= ASAtene 22-23, N.S. 6-7, 1944-1945), Bergamo.

Segre, M. 1993. Iscrizione di Cos 1-2 (Monografie della scuola archeologica di Atene e delle missioni italiane in Oriente, 6), Roma.

Sherwin-White, S. 1978. Ancient Cos. An historical study from the Dorian settlement to the Imperial period (= Hypomnemata 51), Göttingen.

$S I G^{3}=$ Sylloge Inscriptionum Graecarum, ed. W. Dittenberger, Leipzig 1915-19213.

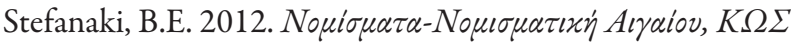
I, Athens.

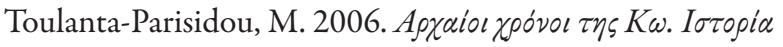

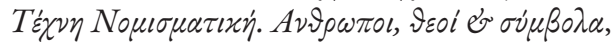
Rhodes.

Touratsoglou, I. \& Tsourti, E. 2006. 'The Pyli Cos/1953 hoard (IGCH 1308). A new approach', Obolos 8 , 381-388.

Waggoner, N.M. 1989. 'A new wrinkle in the Hellenistic coinage of Antioch/Alabanda', in Kraay - Morkholm essays. Numismatic studies in memory of C. M. Kraay and O. Morkholm (Numismatica Lovaniensia, 10), ed. G. Le Rider, Louvain-la-Neuve, 283-290. 

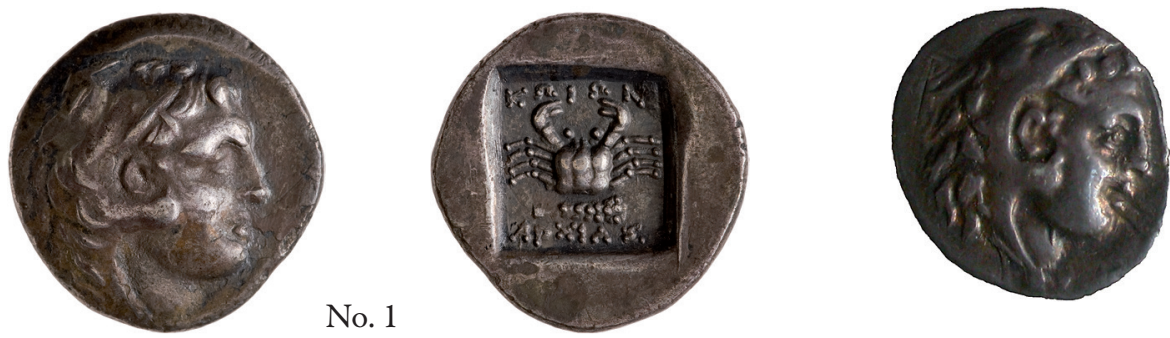

No. 2
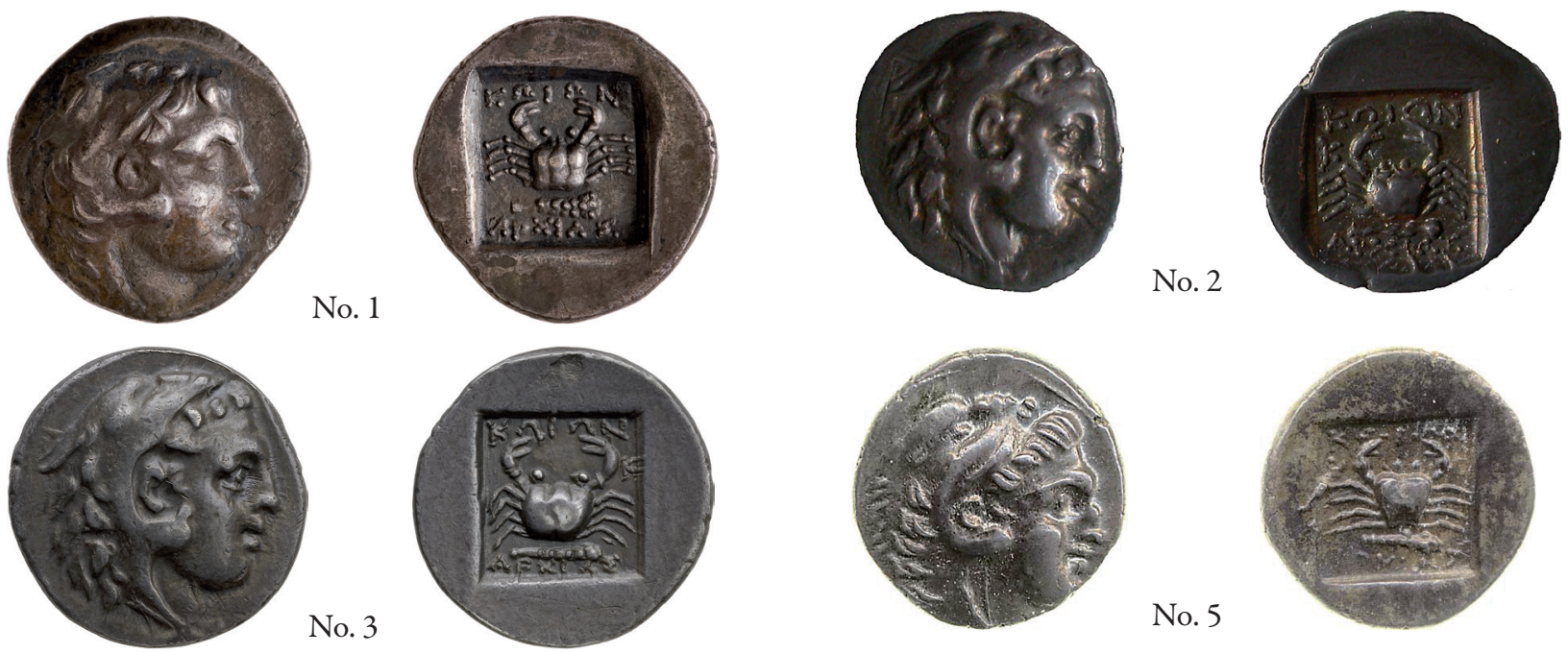

No. 5
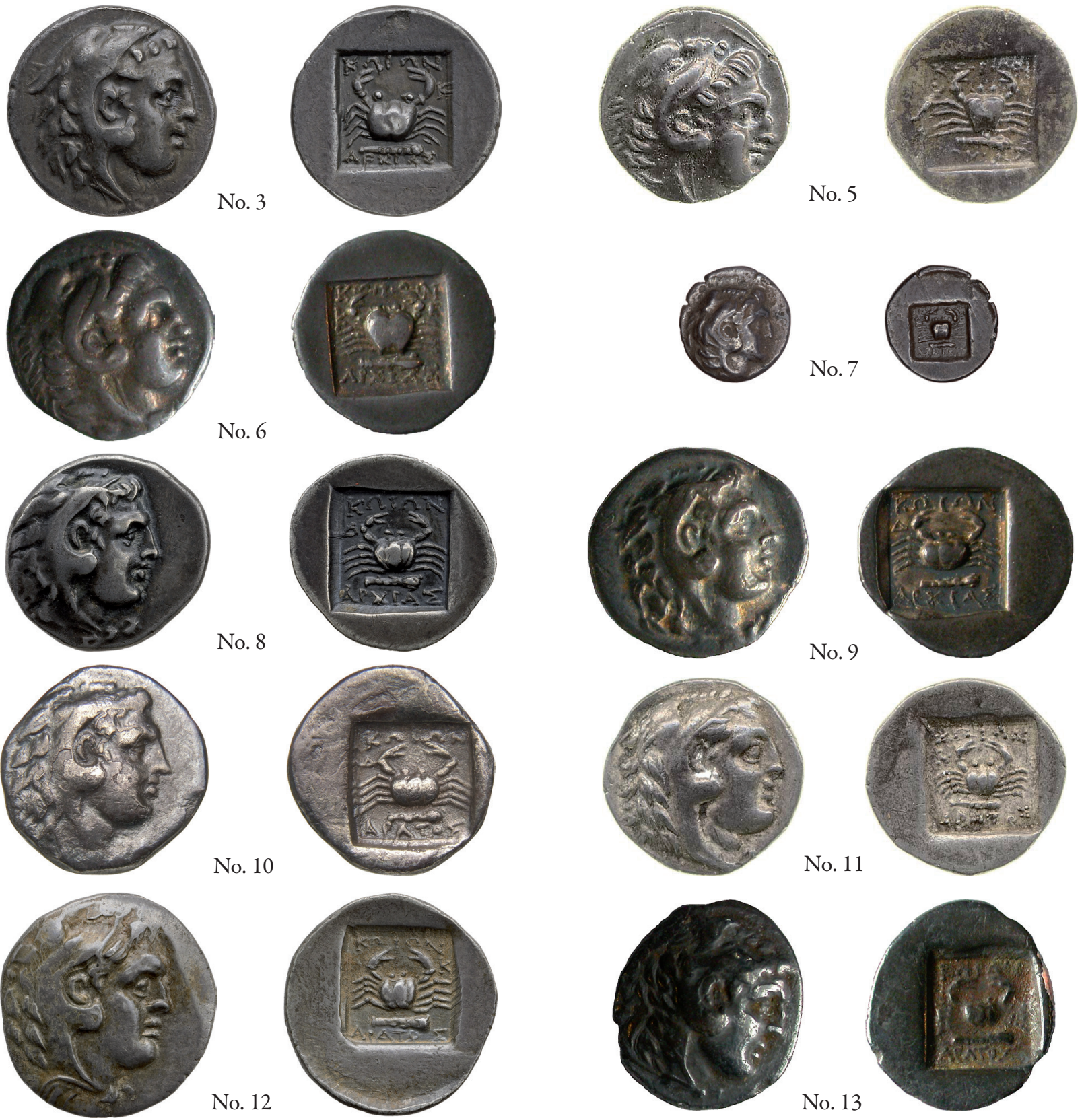

No. 13

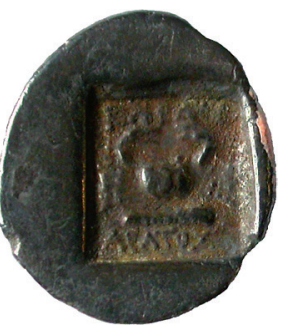

Pl. 1. Young Herakles/incuse drachms. Coins nos. 1-3, 5-13, scale 2:1, except no. 7, 1:1. 


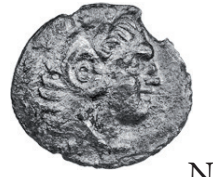

No. 14
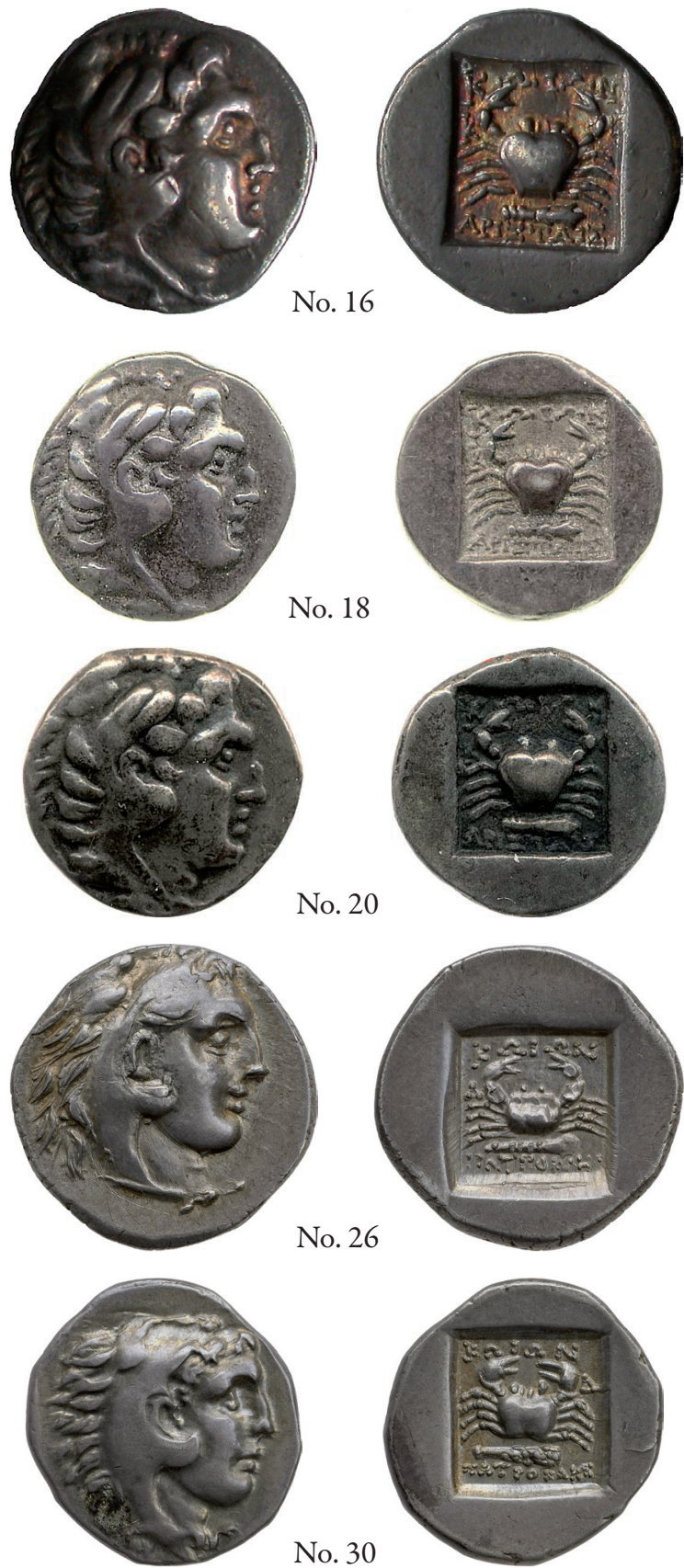
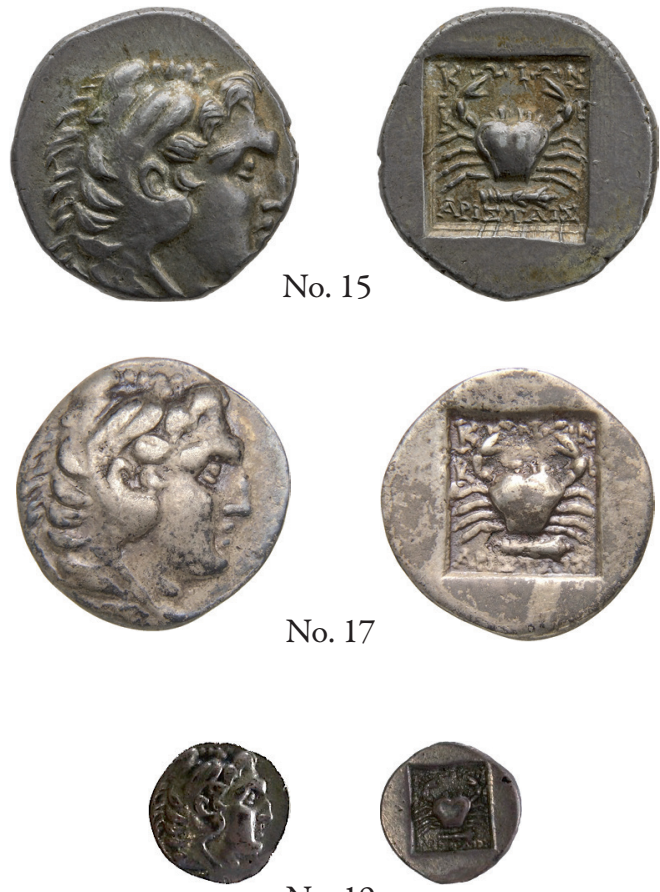

No. 19
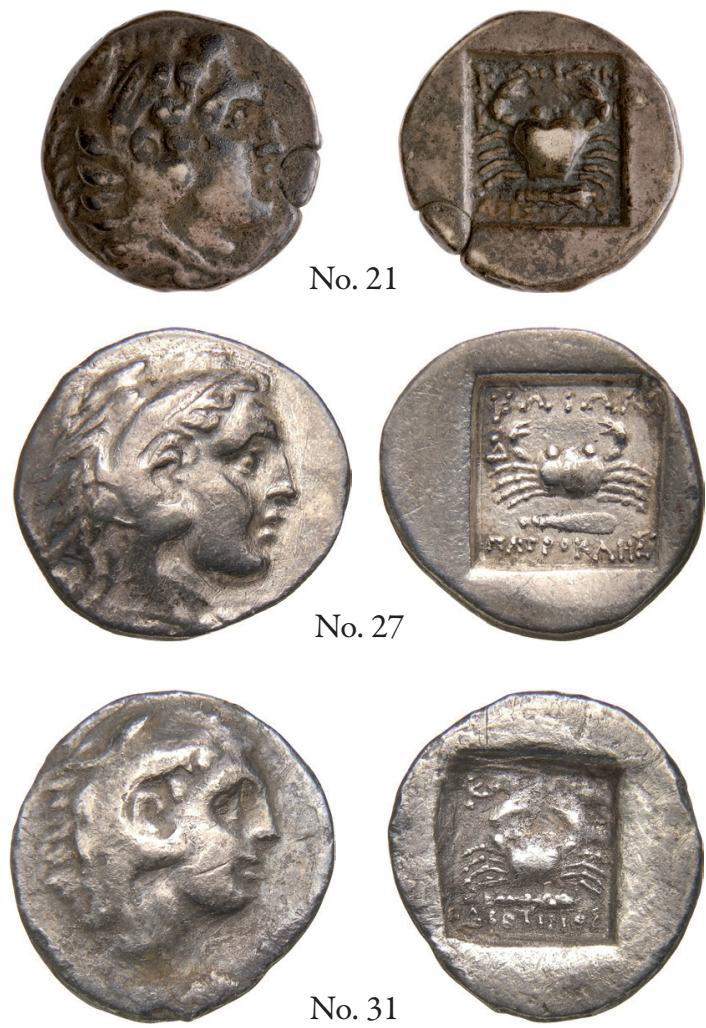

Pl. 2. Young Herakles/incuse drachms. Coins nos. 14-21, 26-27, 30-31, scale 2:1, except nos. 14 \& 19, 1:1. 

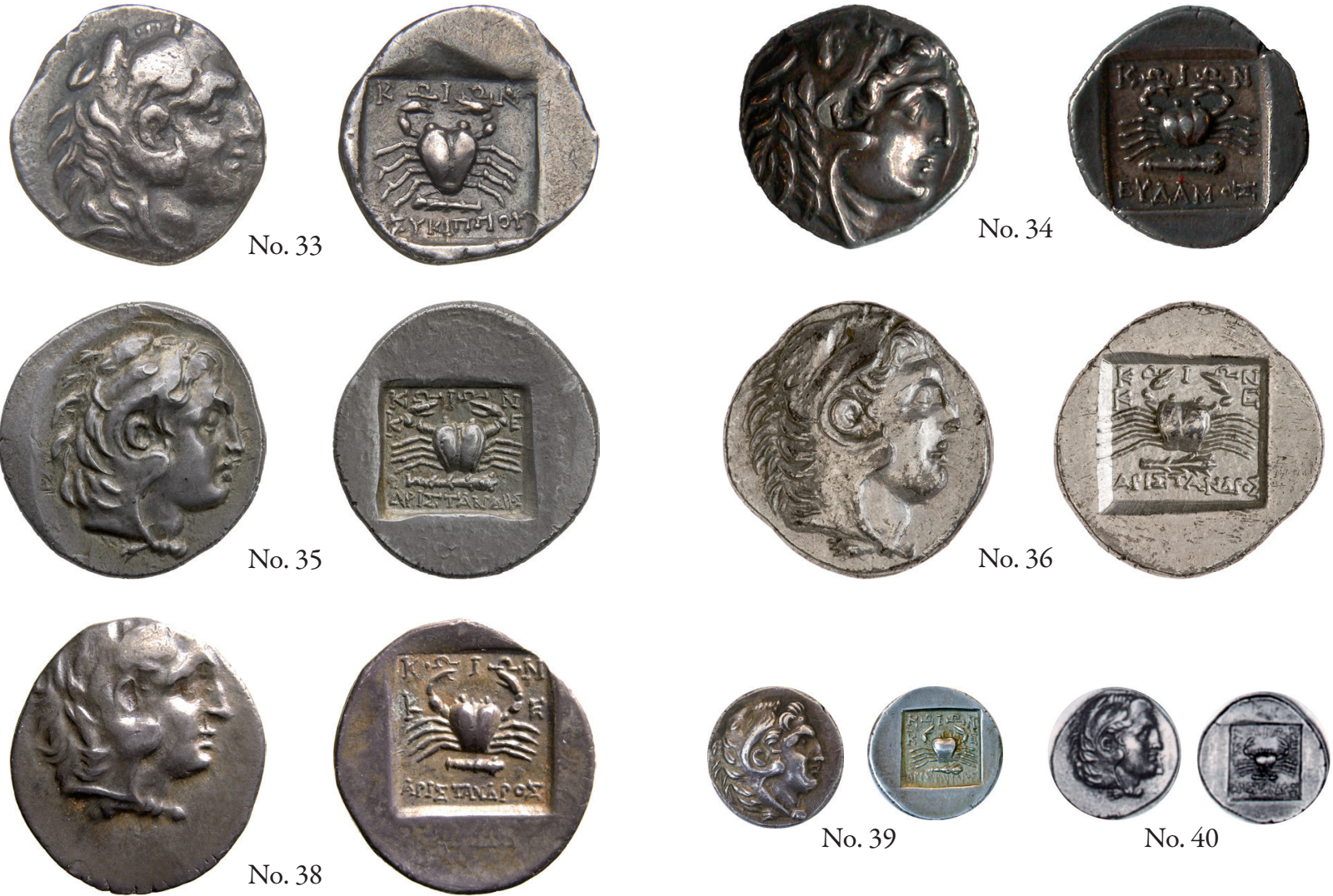

No. 39

No. 40
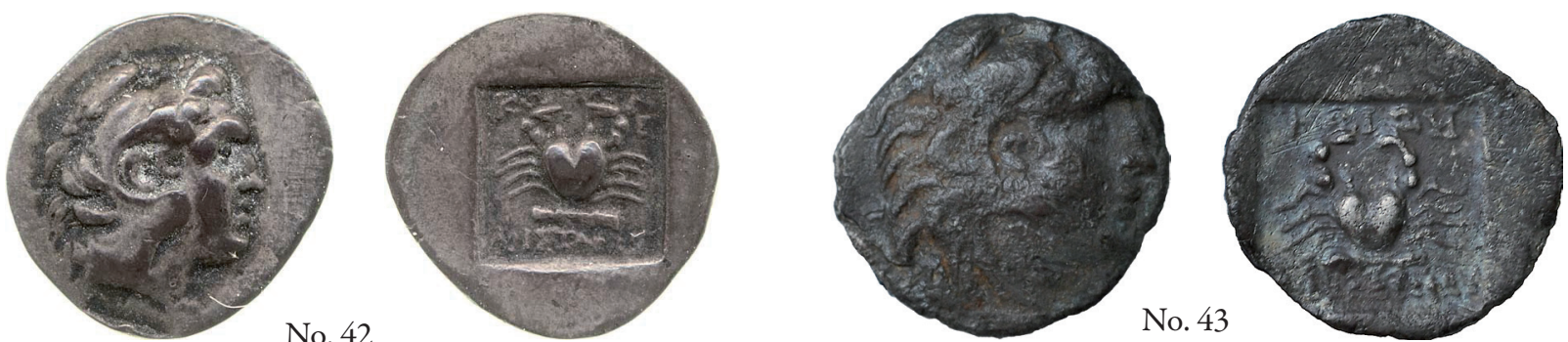

Pl. 3. Young Herakles/incuse drachms. Coins nos. 33-36, 38-40, 42-43, scale 2:1 except nos. 39 \& 40, 1:1. 

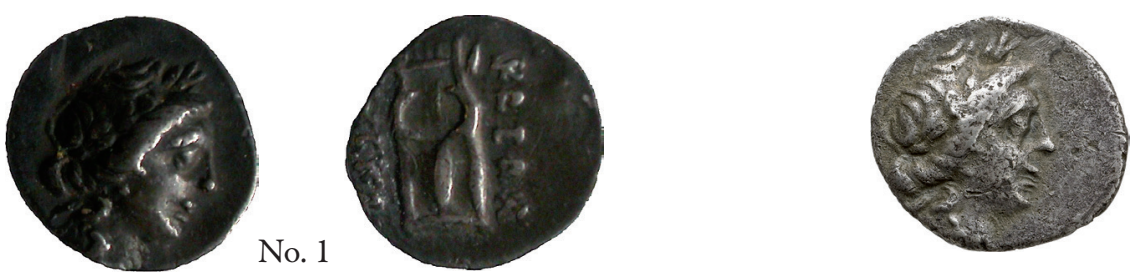

No. 3
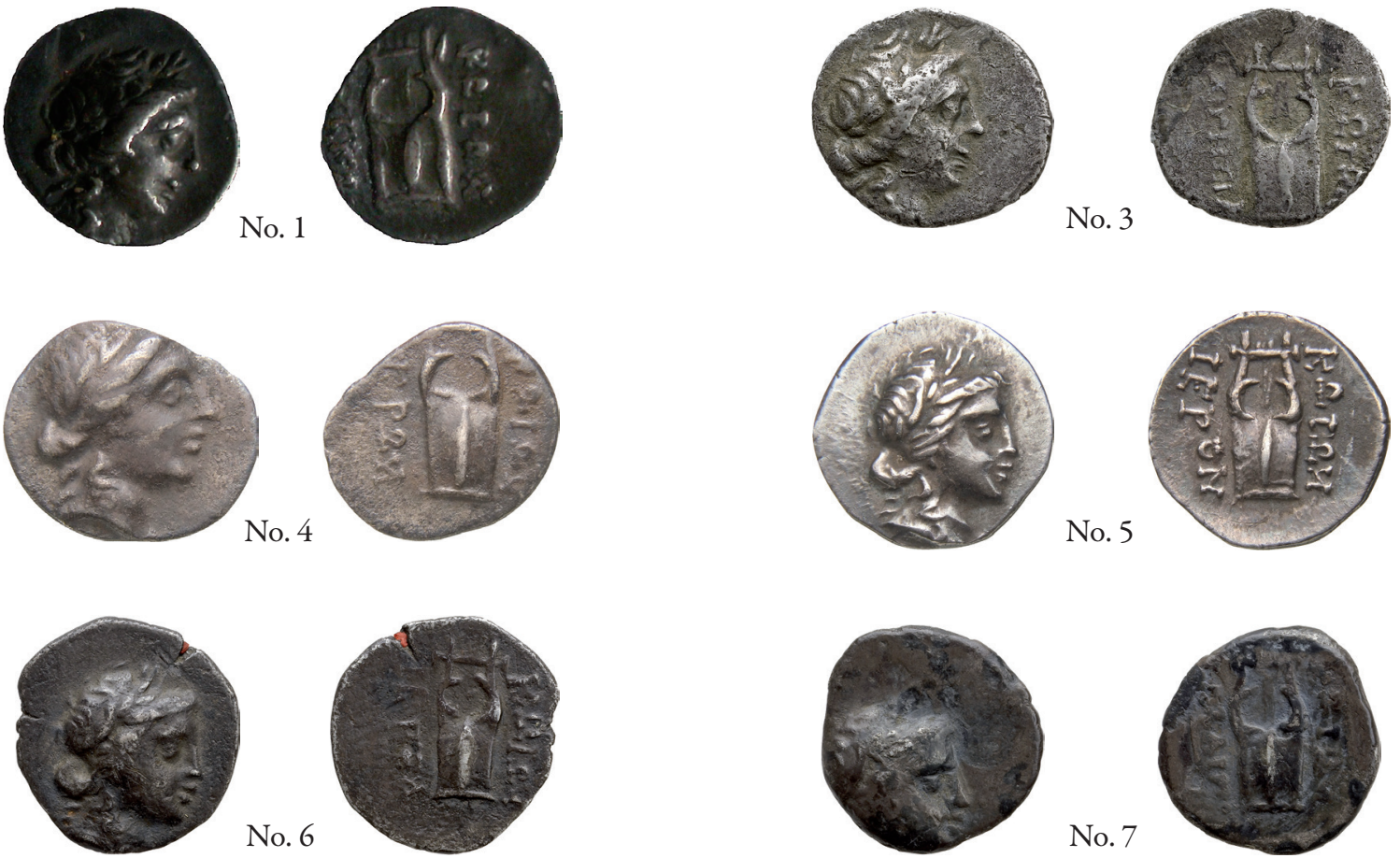

No. 7
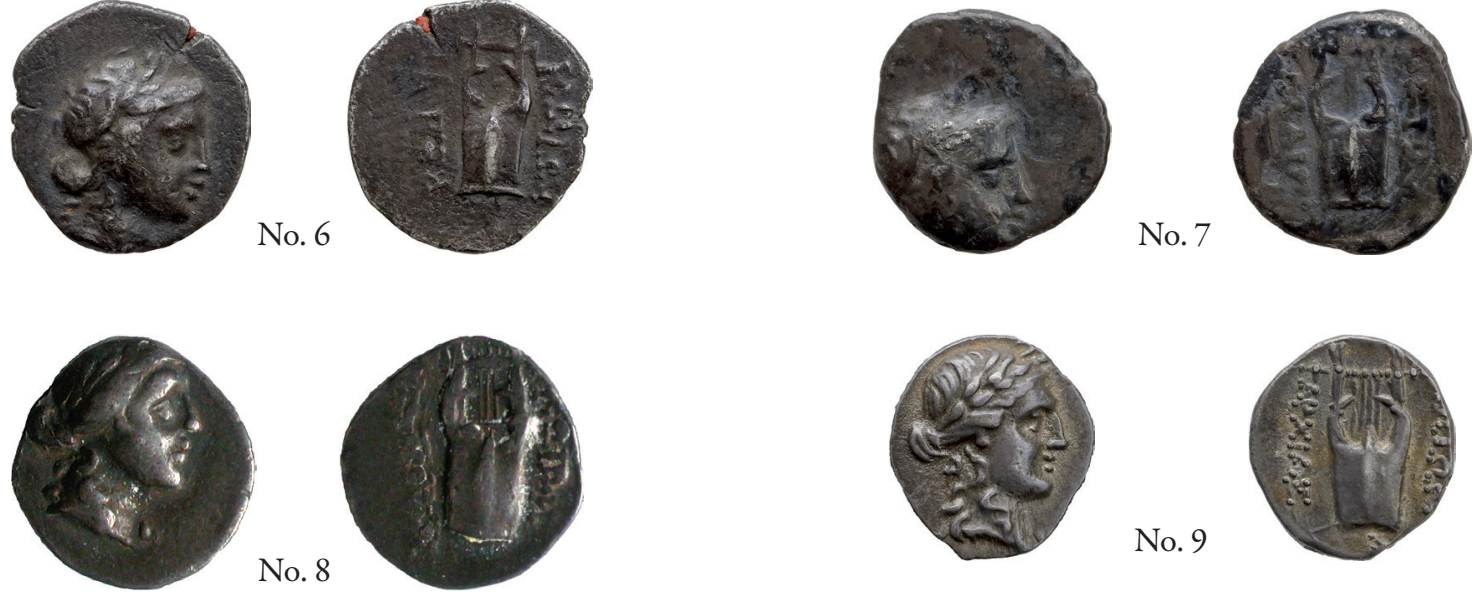

No. 9
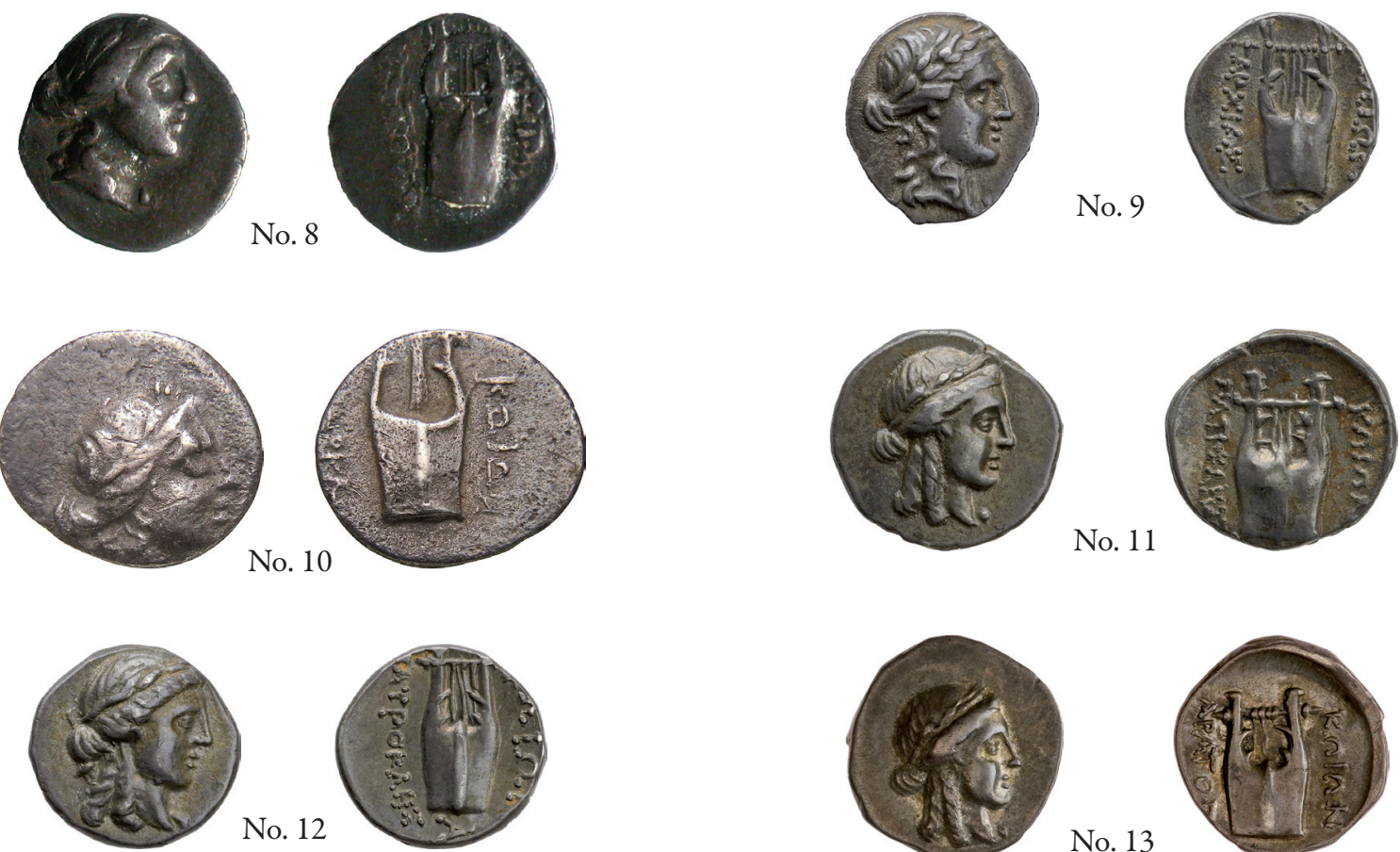

No. 12
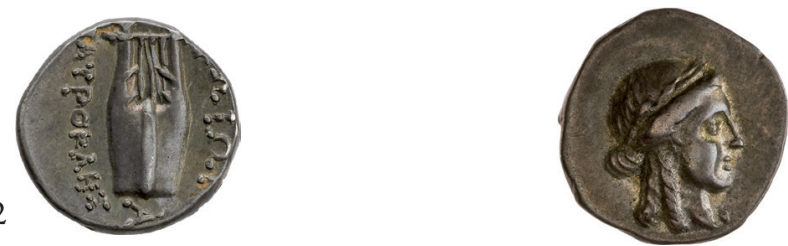

No. 13

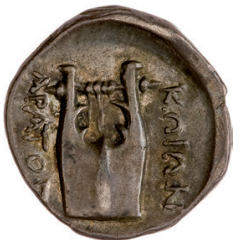



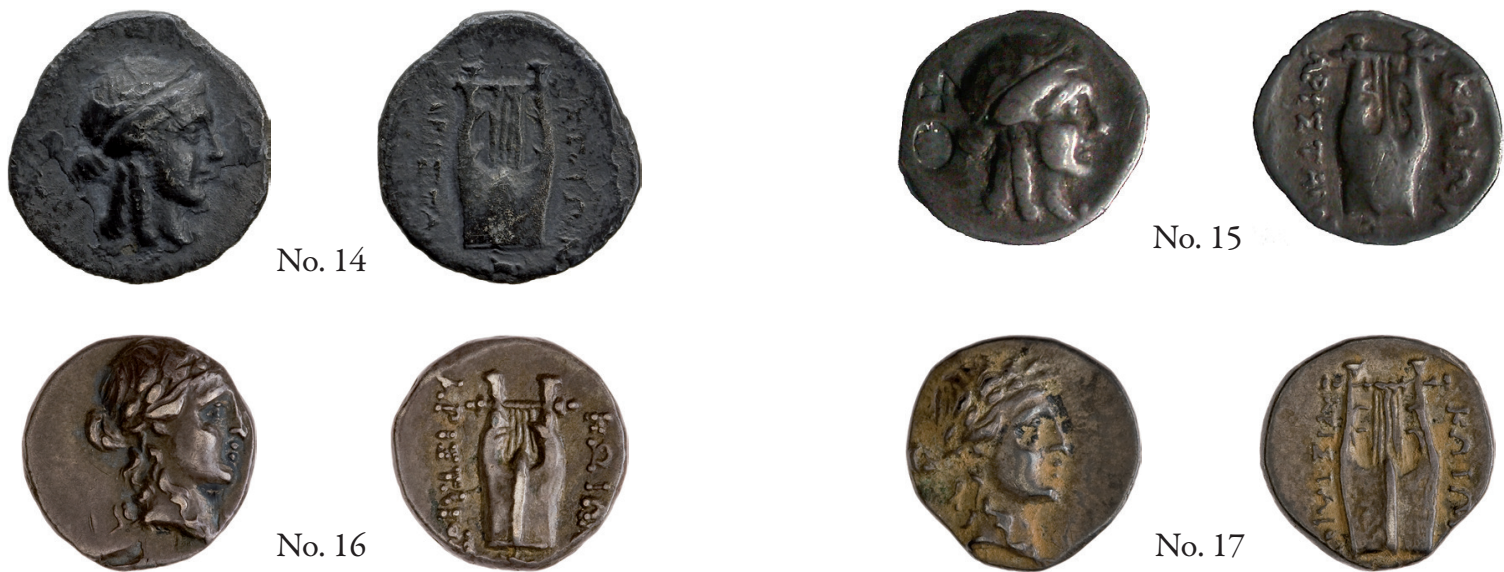

No. 16
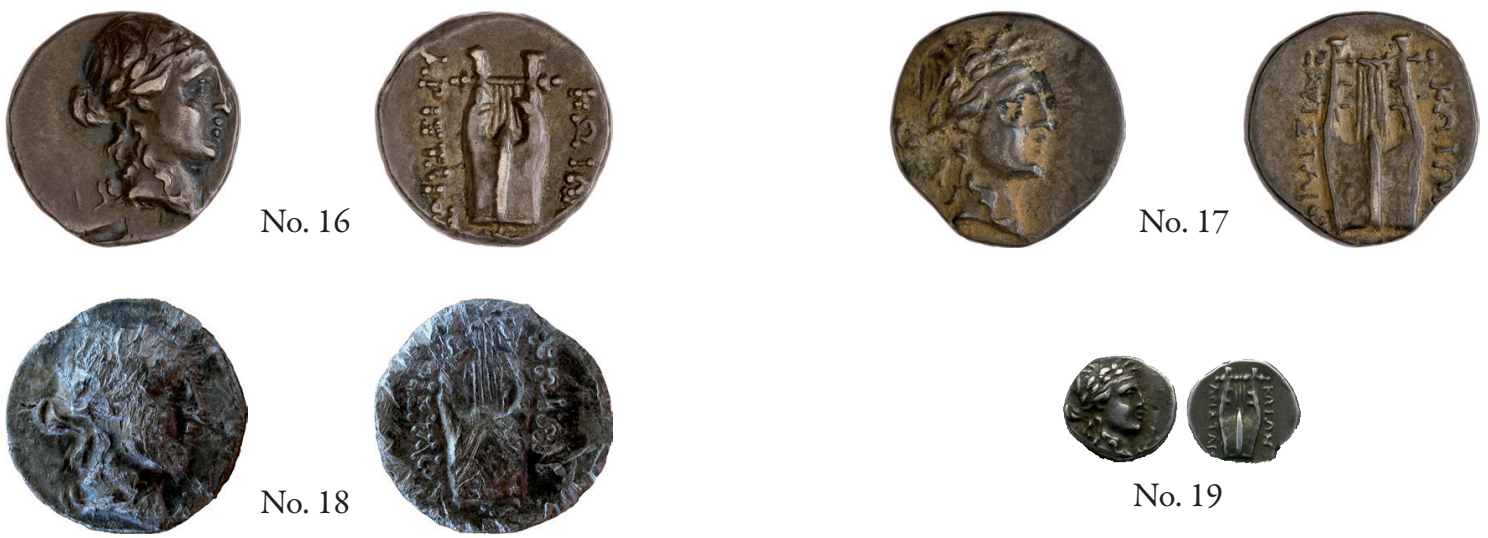

No. 18
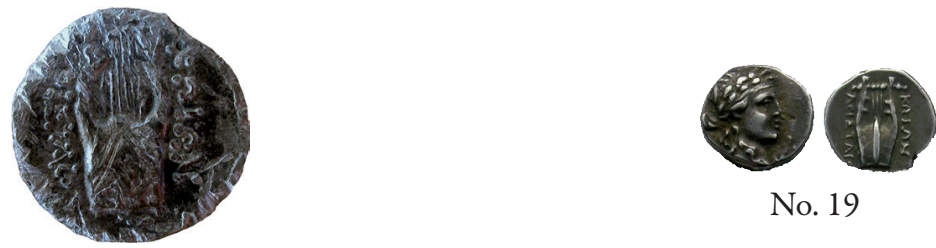

No. 19
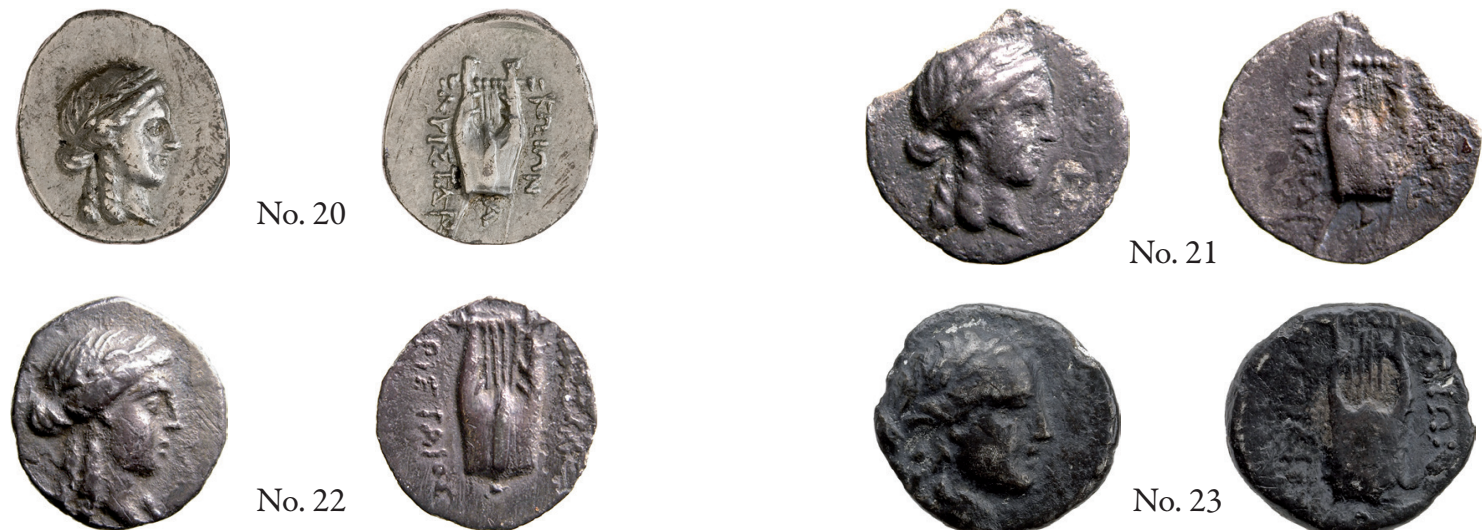

No. 22
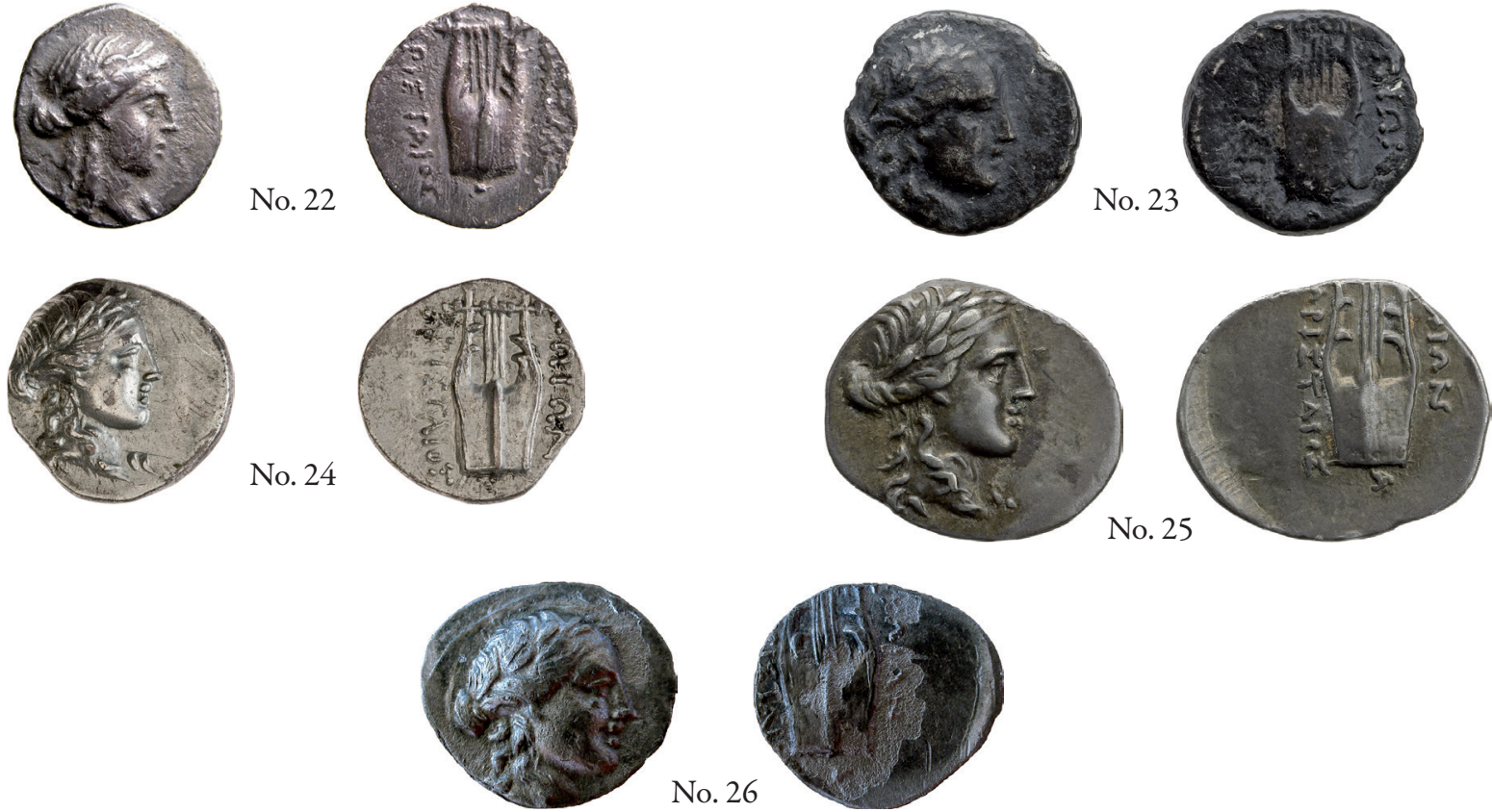

Pl. 5. Apollo/lyre hemidrachms. Coins nos. 14-26, scale 2:1, except no. 19, 1:1. 

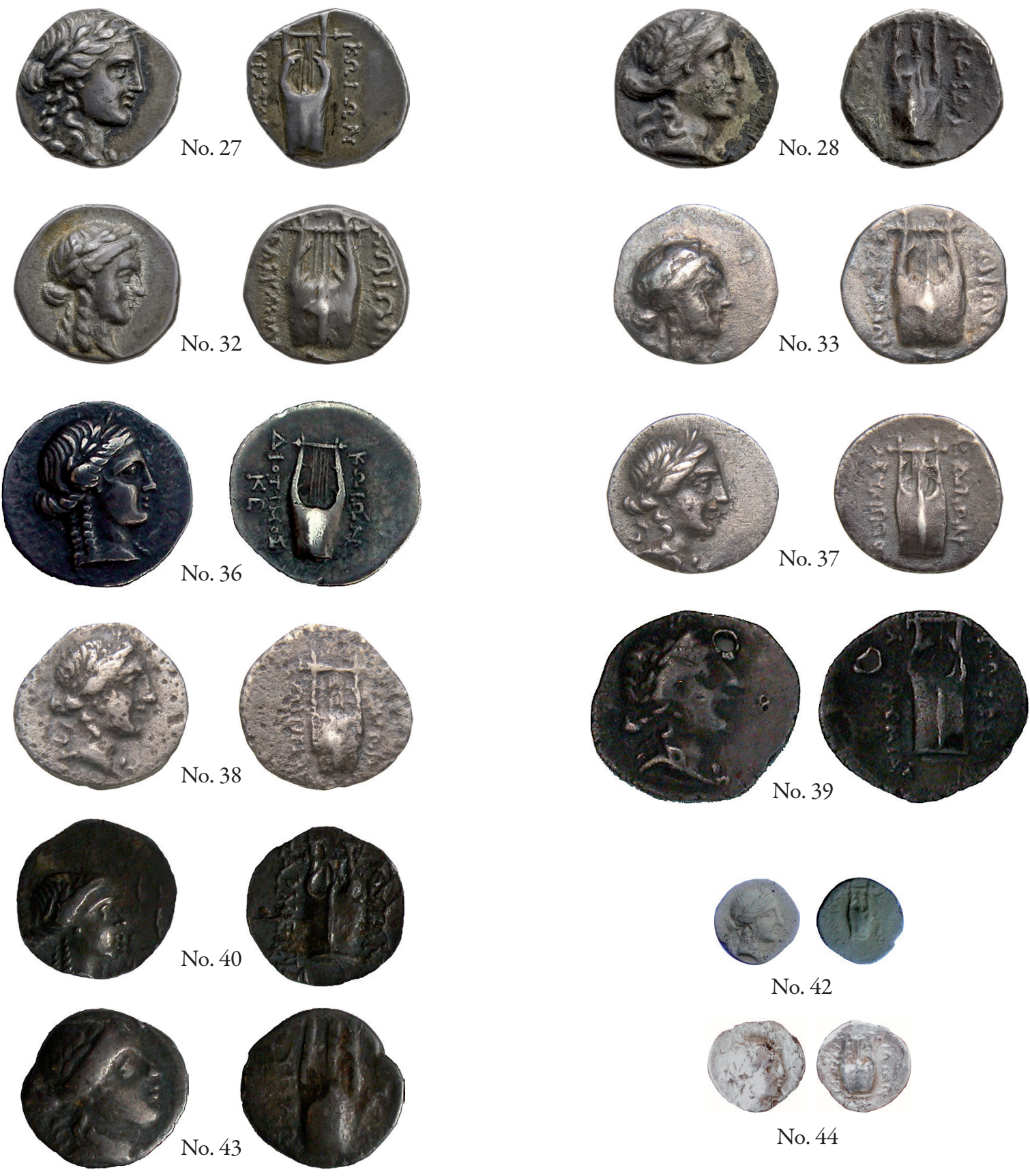

No. 42

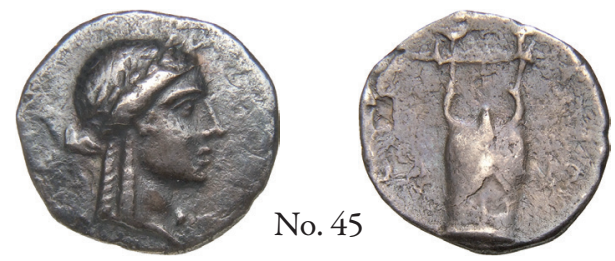

Pl. 6. Apollo/lyre hemidrachms. Coins nos. 27-28, 32-33, 36-40, 42-45, scale 2:1, except nos 42 \& 44, scale 1:1. 


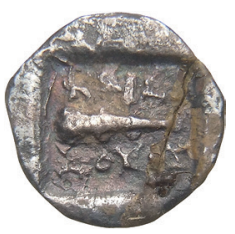

Pl. 7. Höghammar 2007, no. A9 (Berlin 18205802).
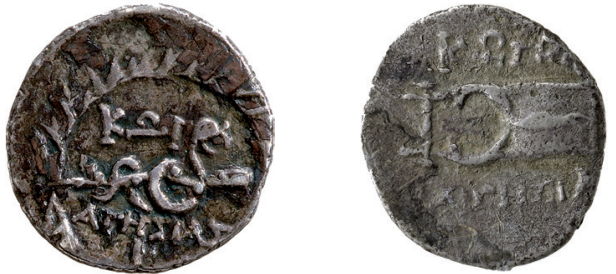

Pl. 9. A comparison of lettering in ethnic and the name Agesias, "Persic" weight hemidrachm, Höghammar 2007 C5, and Apollo hemidrachm no. 3.
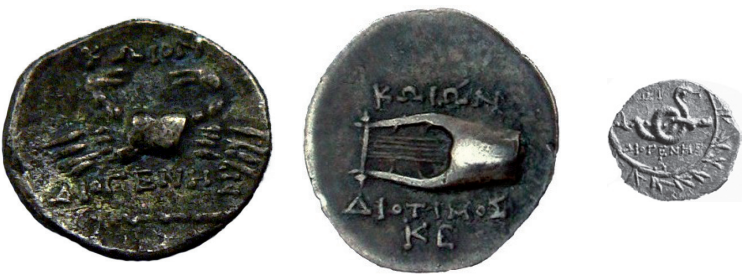

Pl. 8. A comparison of lettering, hemidrachms, HI XIII, Athens NM, Apollo hemidrachm no. 36 and "Persic" hemidrachm, Höghammar 2007 C6.
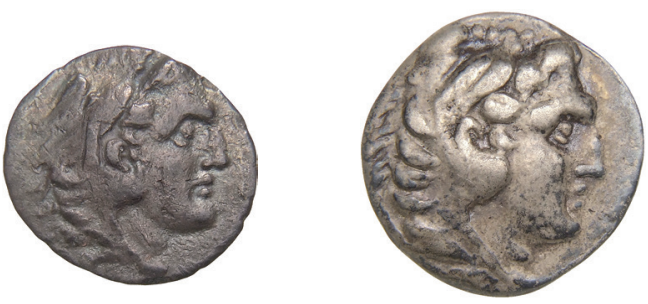

Pl. 10. A stylistic comparison of the Young Herakles head, Höghammar 2007 A6, and Herakles/incuse drachm, no. 17. 